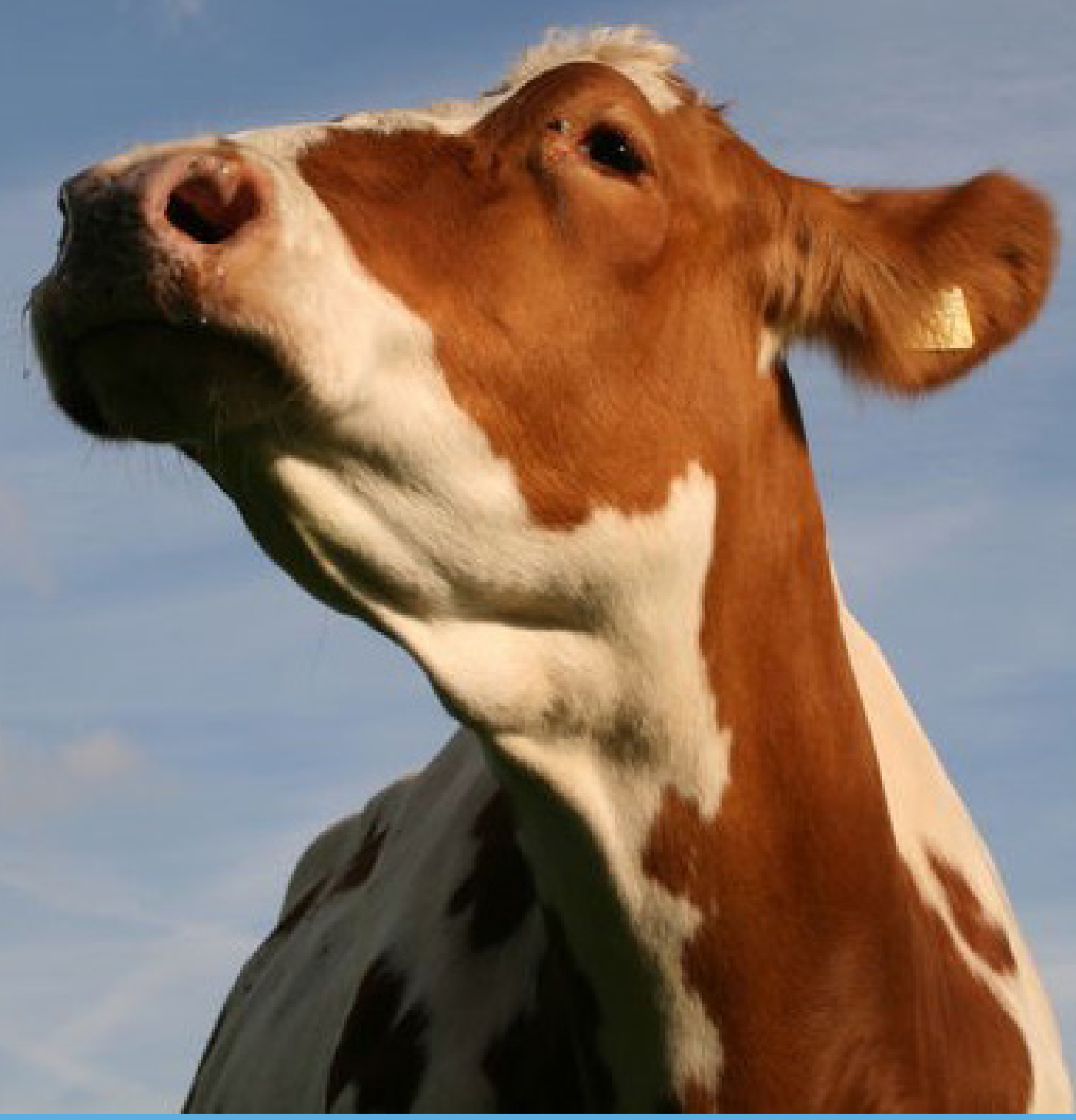

Scheiding van urine en feces bij melkvee: fysiologie, gedragsherkenning en techniek 



\section{Scheiding van urine en feces bij melkvee: fysiologie, gedragsherkenning en techniek}

N. Verdoes, S. Bokma (Editors)

Wageningen Livestock Research

Dit onderzoek is uitgevoerd door Wageningen Livestock Research en gefinancierd door het Melkveefonds, en Ebbers Metalworks BV

Wageningen Livestock Research

Wageningen, september 2017

Rapport 1041 
N. Verdoes, S. Bokma, 2017. Scheiding van urine en feces bij melkvee: fysiologie, gedragsherkenning en techniek. Wageningen Livestock Research, Rapport 1041.

\section{Samenvatting NL}

Het rapport beschrijft een aantal verkennende onderzoeken die een gezamenlijk einddoel hebben, namelijk om bij melkvee te komen tot een systeemdoorbraak waarbij mest en urine direct uit het dier (al dan niet gescheiden) kunnen worden opgevangen en worden afgevoerd.

\section{Summary UK}

The report describes a series of exploring studies and experiments with a communal target, namely to distinguish solutions for a system innovation in dairy housing, in which faeces and urine can be collected automatically and without contaminating the barn floor.

Dit rapport is gratis te downloaden op https://doi.org/10.18174/420092 of op www.wur.nl/livestock-research (onder Wageningen Livestock Research publicaties).

\section{(C) 2017 Wageningen Livestock Research}

Postbus 338, 6700 AH Wageningen, T 03174839 53, E info.livestockresearch@wur.nl, www.wur.nl/livestock-research. Wageningen Livestock Research is onderdeel van Wageningen University \& Research.

Wageningen Livestock Research aanvaardt geen aansprakelijkheid voor eventuele schade voortvloeiend uit het gebruik van de resultaten van dit onderzoek of de toepassing van de adviezen.

Alle rechten voorbehouden. Niets uit deze uitgave mag worden vermenigvuldigd en/of openbaar gemaakt worden door middel van druk, fotokopie, microfilm of op welke wijze dan ook zonder voorafgaande toestemming van de uitgever of auteur.

De certificering volgens ISO 9001 door DNV onderstreept ons kwaliteitsniveau. Op als onze onderzoeksopdrachten zijn de Algemene Voorwaarden van de Animal Sciences Group van toepassing. Deze zijn gedeponeerd bij de Arrondissementsrechtbank Zwolle. 


\section{Inhoud}

$\begin{array}{ll}\text { Woord vooraf } & 5\end{array}$

$\begin{array}{ll}\text { Samenvatting } & 6\end{array}$

1

$\begin{array}{ll}\text { Inleiding } & 9\end{array}$

1.1 Achtergrond $\quad 9$

1.2 Belang voor de melkveehouderij en milieu 9

1.3 Doel van de studie $\quad 9$

$\begin{array}{lll}1.4 & \text { Indeling rapport } & 10\end{array}$

$\begin{array}{ll}\text { Literatuurstudie uitscheidingsgedrag runderen } & 11\end{array}$

$\begin{array}{lll}2.1 & \text { Inleiding } & 11\end{array}$

$\begin{array}{lll}2.2 & \text { Anatomie en fysiologie } & 11\end{array}$

2.3 Natuurlijk uitscheidingsgedrag van runderen 13

2.4 Bevorderende en remmende/ uitstellende factoren voor mesten/ urineren 15

2.5 Opwekken van uitscheidingsgedrag 16

$\begin{array}{lll}2.6 & \text { Sturen van uitscheidingsgedrag van runderen } & 17\end{array}$

3

$\begin{array}{lr}\text { Creatieve sessies } & 18\end{array}$

$\begin{array}{llr}3.1 & \text { Opzet } & 18\end{array}$

3.2 Resultaten $\quad 19$

3.2.1 Functionele mogelijkheden $\quad 19$

$\begin{array}{ll}3.2 .2 \text { Uitwerkingen } & 19\end{array}$

$4 \quad$ Pilot onderzoek trainen van koeien $\quad 21$

$\begin{array}{lll}4.1 & \text { Inleiding } & 21\end{array}$

$\begin{array}{lll}4.2 & \text { Aanpak trainingen } & 21\end{array}$

$\begin{array}{lll}4.3 & \text { Herziene trainingsmethode } & 23\end{array}$

$5 \quad$ Detectie van eliminaties (lozing van mest en urine) van melkvee 24

$\begin{array}{lll}5.1 & \text { Inleiding } & 24\end{array}$

$\begin{array}{lll}5.2 & \text { Ontwikkeling detectiemethode } & 25\end{array}$

$\begin{array}{lll}5.3 & \text { Verzamelde gegevens over lozingen } & 27\end{array}$

5.4 Verkenning voorspelbaarheid lozingen $\quad 29$

5.5 Samenvatting en conclusies $\quad 29$

5.5.1 Ontwikkelde methode voor verzamelen gegevens over mesten en
urineren

5.5.2 Gedrag, verzamelde gegevens en voorspelbaarheid van lozingen 30

$\begin{array}{ll}\text { 5.5.3 Betekenis van de bevindingen } & 30\end{array}$

6.1 Inleiding $\quad 32$

6.2 Aanpak 32

6.3 Stimulatieprotocol voor opwekken urineren 32

6.4 Welke externe stimuli hebben effect?

$\begin{array}{lll}6.5 & \text { Voorlopige conclusies } & 35\end{array}$ 
$\begin{array}{lll}7.1 & \text { Prototype } & 36\end{array}$

$\begin{array}{lll}7.2 & \text { Praktijkverkenning met urineerbox } & 37\end{array}$

$\begin{array}{lll}8.1 & \text { Massabalans } & 38\end{array}$

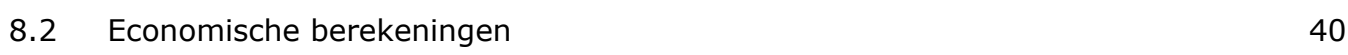

$9 \quad$ Berekening perspectief $\mathrm{NH}_{3}$-emissiereductie $\quad 43$

$\begin{array}{lll}9.1 & \text { Achtergrond } & 43\end{array}$

9.2 Praktische consequenties $\quad 43$

9.3 Emissiemodel 44

9.4 Effect opvangen van urine en gevolgen voor ammoniakemissie $\quad 44$

$\begin{array}{lll}9.5 & \text { Resultaten } & 44\end{array}$

10 Maatschappelijke acceptatie en effectiviteit van een urineerbox 47

$\begin{array}{lll}10.1 & \text { Aanleiding vraag } & 47\end{array}$

$\begin{array}{ll}10.2 & \text { Korte toelichting onderzoek }\end{array}$

10.2.1 Publieksonderzoek naar de maatschappelijke acceptatie van het gebruik van een closet voor koeien, gekoppeld aan zindelijkheidstraining $\quad 47$

10.2.2 Praktijkonderzoek naar de effectiviteit van het gebruik van de urineerbox in het kader van ammoniakreductie $\quad 48$

10.2.3 Funderend onderzoek naar de effecten van het gebruik van de urineerbox op het welzijn van koeien $\quad 48$

$\begin{array}{lll}10.3 & \text { Visie op de praktische haalbaarheid } & 48\end{array}$

$\begin{array}{ll}\text { 10.3.1 Haalbaarheid in maatschappij } & 49\end{array}$

11 Discussie, conclusies, aanbevelingen $\quad 50$

$\begin{array}{lll}11.1 & \text { Discussie en conclusies } & 50\end{array}$

$\begin{array}{ll}11.2 \text { Aanbevelingen } & 51\end{array}$

Bijlage 1 Deelnemers creatieve sessie $\quad 56$

$\begin{array}{lll}\text { Bijlage } 2 & \text { Economische uitgangspunten en resultaten } & 57\end{array}$ 


\section{Woord vooraf}

Waar een onderzoek voucher al niet toe kan leiden. Het bedrijf Ebbers Metalworks BV uit Doetinchem had een voucher aangevraagd voor onderzoek naar het separaat opvangen van urine bij melkkoeien en deze voucher uitgezet bij Wageningen Livestock Research. In eerste instantie is een literatuuronderzoek verricht naar de fysiologie van het mesten en het urineren en naar het uitscheidingsgedrag bij koeien.

Het thema "scheiden aan de bron" heeft al jaren aandacht in de onderzoekswereld. De voorstudie, de aandacht vanuit het onderzoek (vanwege de vele positieve potenties) en de belangstelling vanuit het bedrijfsleven was reden om een groter project aan te vragen bij het Melkveefonds (Milk Advisory Board van LTO Nederland en Wageningen Research). In het onderhavige rapport wordt gerapporteerd wat het onderzoek tot nu toe heeft opgeleverd.

Eén van de deelonderzoeken is uitgevoerd door studenten van het Van Hall Instituut uit Leeuwarden. Bedankt voor de inzet.

Bij de brainstormsessies zijn mensen op basis van persoonlijke achtergrond, interesse en creativiteit uitgenodigd. Dank voor de inspiratie en betrokkenheid bij dit onderwerp.

In dit rapport zijn 3 tekeningen opgenomen, die JAM visual thinking gemaakt heeft in het kader van het project EDD 2020 (Environmental Dairy Design 2020). Dank voor het gebruik. In EDD 2020 zoekt men naar innovatieve huisvestingssystemen voor rundvee met lage ammoniakemissie. Vanwege de raakvlakken die er tussen beide projecten zijn, is er steeds kennis uitgewisseld.

Nico Verdoes en Sjoerd Bokma 


\section{Samenvatting}

Nico Verdoes en Sjoerd Bokma

Het scheiden (bedoeld wordt het voorkómen van vermenging) van feces en urine bij de bron vermindert de ammoniak- en methaanemissie vanuit de stal. De afzonderlijke mestproducten kunnen beter bewerkt of gerichter aangewend worden. Het doel van deze studie was om tot een doorbraak te komen in separate opvang en afvoer van feces en urine van melkvee, vóórdat beide fracties op de vloer komen. (Rooster-)vloeren met gescheiden afvoer waren dus niet de focus van deze studie, maar wel de fysiologie en het diergedrag bij mesten/urineren en de mogelijkheden om via techniek en automatisering de opvang en afvoer te realiseren.

Vooraf is een literatuurstudie uitgevoerd naar de fysiologie en het gedrag bij uitscheiding van koeien. Zowel de sluitspier van de urinebuis als die van de anus bestaat uit dwarsgestreept spierweefsel. Runderen zijn zich er van bewust indien ze mesten of urineren en vermoedelijk zijn ze ook in staat om de aandrang tijdelijk te onderdrukken. Mogelijk dat dit pas enige tijd na de geboorte het geval is. Van nature blijken runderen wel degelijk contact met hun eigen mest te vermijden, maar in een ligboxenstal is dat nauwelijks het geval.

In twee creatieve sessies is de kennis over dit thema geordend, zijn veel creatieve ideeën geuit en vervolgens zijn drie vernieuwende ideeën geselecteerd. Deze drie opties om mestfracties direct uit het dier apart op te vangen, zijn in deze studie opgepakt, te weten:

1. het trainen van koeien om op een bepaalde plek te urineren via beloning,

2. het inzetten van "big data" en meetapparatuur (om de uitscheiding te kunnen voorspellen) en

3. het ontwikkelen van een urineerbox.

De uitwerking van een 4e optie (opvangen van mestfracties na het opstaan van dieren) is uitgesteld, omdat eerst inzicht verkregen moest worden in de plaats en tijdstippen van elimineren.

Ad 1:

Waarschijnlijk is het uitscheidingsgedrag van runderen wel te sturen door middel van training, maar vooralsnog is daarbij niet duidelijk of hiermee ook zodanig gestuurd kan worden dat contact van mest en urine wordt verminderd. Training kan er enerzijds op zijn gericht om dieren te leren zodra ze op een bepaalde plaats zijn te urineren of mesten ofwel de aandrang op te wekken of de remming op te heffen. Anderzijds kan de training er op zijn gericht om dieren te leren zodra ze aandrang krijgen deze tijdelijk te onderdrukken en zich naar een gewenste plaats te begeven. Ook kan training worden overwogen waarbij dieren waarvan bijvoorbeeld wordt vermoed dat ze een redelijk volle blaas hebben met bijvoorbeeld een geluidssignaal worden geprikkeld om zich naar een gewenste plaats, bijvoorbeeld een "urineerbox", te begeven. Hoe en op welke leeftijd dieren het beste getraind kunnen worden, en hoe op een praktische manier naast training gestuurd kan worden is nog niet uitgekristalliseerd.

In een trainingsexperiment is koeien geleerd om een fluitsignaal te associëren met de voerbeloning. Vervolgens is de koe blootgesteld aan het fluitsignaal direct nadat zij heeft geürineerd, waarna de voerbeloning volgde op de plek van urineren. Koeien laten zien dat ze de link leggen tussen fluitsignaal, urineren en een voerbeloning. Deze fase van het beoogde conditioneringsproces werd succesvol afgerond. Het uiteindelijke doel van de training was dat een koe zich naar een specifieke plaats begeeft om daar te urineren, waarna het fluitsignaal klinkt en de voerbeloning wordt verstrekt. Deze gewenste reacties zijn niet of nauwelijks waargenomen na 17 trainingsdagen. Het perspectief van deze training werd in het kader van dit onderzoek niet voldoende geacht. Het feit dat alleen lozingen van urine en mest gedurende de dag werden gecombineerd met het fluitje in combinatie met de voerbeloning betekende dat alle eliminaties gedurende de avond en nacht onbeloond bleven. Dit kan het leerproces vertraagd en wellicht zelfs voorkómen hebben. Een aangepast trainingsschema is uitgewerkt, maar in dit onderzoek nog niet toegepast. 
Ad 2:

$\mathrm{Er}$ is een methode ontwikkeld (staartsensoren) om lozingen van mest en urine van melkkoeien op een efficiënte manier nauwkeurig te registreren naar tijd, plaats en individu. De methode is gebaseerd op het feit dat bij lozingen vrijwel altijd de staart wordt opgetild en dat lozingen ook visueel waarneembaar zijn. Vastgesteld is dat vrijwel alle lozingen op grond van staartbewegingen kunnen worden opgespoord. Naast attenties als indicator voor mogelijke lozingen van mest en urine is wel aanvullende informatie nodig om bij attenties onderscheid te kunnen maken tussen mesten, urineren en vals positieve attenties om betrouwbare gegevens te kunnen verzamelen. Deze informatie wordt bij de ontwikkelde methode verkregen uit visuele controle van beeldmateriaal voor de tijdspannes dat er attenties zijn van de staartsensoren.

Uit de verzamelde gegevens blijkt dat de onderzochte melkkoeien per etmaal gemiddeld circa 15 keer mestten en 9 keer urineerden, maar dat de individuele variatie groot was: van 9.4 tot 28.1 keer voor mesten en van 5.1 tot 17.2 keer voor urineren. Bij urinelozingen werd de staart gemiddeld iets langer opgetild dan bij mestlozingen (43 vs. 33 seconden). Er lijkt geen sterk verband te zijn tussen de frequentie van mesten en urineren. Lozingen vinden verspreid over het etmaal plaats, ook tijdens de nachtelijke uren. Bij opstaan en gaan liggen vinden relatief vaak lozingen plaats, alle urinelozingen en het merendeel van de mestlozingen gebeuren terwijl dieren staan of lopen. De intervallen tussen opeenvolgende lozingen van individuele dieren variëren sterk. Op vrijwel de hele beschikbare loopruimte worden mest- en urinelozingen gedeponeerd, maar de vloerstrook van de mestgang direct achter het voerhek wordt aanzienlijk minder vaak gemest en geürineerd dan de rest van de vloer achter de ligboxen.

Ad 3:

De mogelijkheden om door gericht stimuleren mesten en urineren op te wekken lijken gering, alleen prikkeling van het perineum lijkt een praktische methode om urineren op gang te brengen. Prikkels als luchtstroom, water of temperatuur zijn mogelijk bruikbaar, maar hiervoor waren nog geen

uitgekristalliseerde toepassingen bekend. Daarom is een verkennend experiment met melkkoeien opgestart om het urineergedrag op te wekken door middel van kortstondige perineum massage. Een borstel met stugge haren als massagemateriaal gaf de beste respons (gemiddeld ca $28 \%$ succesvolle urinaties). Er lijkt bovendien sprake te zijn van stijging van de respons naarmate de koeien meer ervaring met de massage krijgen. In het experiment kregen de koeien geen beloning als zij het gewenste unineergedrag vertoonden. De koeien werden ad random gestimuleerd, zonder kennis van het voorgaande tijdstip waarop een urinelozing plaatsvond. Uit aanvullende waarnemingen van een dierenarts naar de vullingsgraad van de blaas kwam naar voren dat het niet reageren op de massage veelal kon worden verklaard door een geringe vulling van de blaas. Wellicht moet er ook meer aandacht worden besteed aan het koppelen van prikkels aan de mate waarin de blaas of het rectum zijn gevuld en training van gewenst gedrag.

Op een praktijkbedrijf is een prototype van een urineerbox (een aangepaste krachtvoerbox waarin urine opgevangen kon worden) beproefd. In een kleine groep droogstaande dieren bleek dat ze bereid zijn om voor een kleine (voer)beloning frequent naar deze box te gaan. Het urineren in de box werd met wat aanvullend en extra smakelijk voer beloond. Ook werd duidelijk dat de dieren een verband leerden te leggen tussen het urineren en het krijgen van de beloning. Het stimulatiemateriaal lijkt een functioneel onderdeel te vormen van het "ritueel" om het urineren zelf in gang te zetten.

Waargenomen werd dat dieren zelf het stimulatiemateriaal opzoeken en vervolgens gaan urineren en de extra beloning in ontvangst nemen. Met deze ervaring is een volgend type box ontwikkeld, dat op een ander praktijkbedrijf is geplaatst. Geëxperimenteerd is in een grotere groep melkgevende dieren en ook of tijdens weidegang er voldoende bezoeken aan de box zouden plaatsvinden. Op het moment van deze rapportage was de conclusie dat de urineerbox kansrijk is, maar er een doorontwikkeling nodig is om een groter aandeel van de urine op te kunnen vangen.

Scenariostudie afzetmogelijkheden en -kosten

In het project is ook een milieukundig/economisch model ontwikkeld om de effecten van gescheiden meststromen op bedrijfsniveau door te rekenen. Hiermee kunnen de verschillende meststromen, de mestbehandelingsmogelijkheden, de besparing op kunstmest bij bemesting met urine, de kosten van deze behandeling en de mogelijkheden in de bemesting van de afzonderlijke mestproducten worden berekend. Ook is gerekend met een N stripper, om een "kunstmestvervanger" te maken. Het 
economische resultaat van het scheiden van mest en urine bij de bron is daarbij afgezet tegen de mest-afzetprijs. Het omslagpunt waarbij scheiden bij de bron in combinatie met de omzetting naar een kunstmestvervanger gunstiger is, ligt bij een afzetprijs rond $€ 10,50$ per ton mest (bij het gebruik van salpeterzuur in de stripper) of bij $€ 22$ per ton mest (bij het gebruik van zwavelzuur). Alleen scheiden aan de bron (de urineerbox) zal economisch niet interessant zijn, omdat beperking van de ammoniakemissie niet financieel wordt beloond. De nevenvoordelen als minder mestafvoer en besparing op kunstmestgebruik kunnen - bij gegeven bedrijfsomstandigheden - de doorslag geven naar een positief economisch resultaat. Er is geen rekening gehouden met voordelen voor diergezondheid. Die kunnen in dit stadium ook nog niet worden gekwantificeerd, maar zouden relevant kunnen zijn.

Ammoniakreductiepotentieel

Met het Snelstal-ammoniakemissiemodel is gesimuleerd hoeveel de emissie zou zijn bij verschillende urineerfrequenties, oppervlakken per dier in de stal en de hoeveelheid urine per lozing. Als $80 \%$ van de urinelozingen per dag opgevangen zou kunnen worden en dus niet op de stalvloer terecht komen, is de verwachte emissiereductie in een gangbare ligboxenstal met roostervloer ca. $56 \%$.

Conclusies en aanbevelingen voor vervolg

Het onderzoek heeft tot op heden vooral een verkennend karakter gehad. Het onderzoek leverde in ieder geval meer kennis op over het (mest- en) urineergedrag van koeien. Het lijkt wel mogelijk de koeien op een specifieke plaats te laten urineren en deze urine separaat op te vangen. Het verdient aanbeveling om het op grotere schaal voort te zetten en een beter beeld te krijgen van de inspanning en succeskans om het gericht urineren in de praktijk te implementeren en de effecten op ammoniakuitstoot in de praktijk vast te kunnen stellen. Technologische ontwikkelingen in de veehouderij leiden in toenemende mate tot kritische beschouwingen en soms zelfs tot negatieve beeldvorming in de samenleving. Verwacht wordt dat voor de urineerbox de vraag zal gesteld worden of het middel (het toilet voor koeien) het doel (reductie van ammoniakemissie en schonere stalvloeren) wel heiligt. Om dit beter te kunnen onderbouwen, wordt het volgende onderzoek voorgesteld:

- Publieksonderzoek naar de maatschappelijke acceptatie van het gebruik van een toilet voor koeien, gekoppeld aan zindelijkheidstraining (de maatschappelijke waarden);

- Praktijkonderzoek naar de effectiviteit van het gebruik van het koeiencloset in het kader van ammoniakreductie (de praktijkvoordelen);

- Funderend onderzoek naar de effecten van het gebruik van het koeientoilet op het welzijn van koeien (de biologische feiten).

- De praktische uitvoering van het toilet (de gewenste beloning, de plaats en uitvoering van de box in de stallen in combinatie met automatisering)

- Andere vormen van trainen of andere vormen van urine opvangen (mogelijkheden van trainen op jongere leeftijd, opvangen in aangepaste logboxen). 


\section{$1 \quad$ Inleiding}

Nico Verdoes

\section{$1.1 \quad$ Achtergrond}

Primaire mestscheiding (het zo goed mogelijk gescheiden houden van feces en urine) in rundveestallen kent veel potentiele voordelen: de ammoniakemissie wordt sterk beperkt, de afzonderlijke mestproducten kunnen beter bewerkt of gerichter aangewend worden, er is meer biogas te winnen uit verse mest, er is minder methaanemissie vanuit de stal (geen diepe mestopslag meer). Er zijn vloer- en afvoersystemen bekend in de rundveehouderij die een gescheiden afvoer van feces en urine beogen, maar deze worden nog relatief weinig toegepast. Een belangrijke reden hiervoor is dat de oplossing tot dusver wordt gezocht in scheiding van de meststromen op, en met behulp van, de loopvloer van het vee, waarbij de gewenste snelle afvoer van urine leidt tot het indrogen van de feces, waardoor deze minder goed te verwijderen is en de loopvloer glad wordt. In het project Kracht van Koeien is dit thema van gescheiden opvang en afvoer van mest en urine expliciet benoemd (Bos et al., 2010). Varkens zijn vanwege hun aangeboren zindelijkheid beter te sturen dan melkvee om op een "toilet" te mesten. Voor de melkveehouderij zal een ander, innovatief, spoor ontwikkeld moeten worden om hetzelfde doel te realiseren.

\subsection{Belang voor de melkveehouderij en milieu}

De ammoniakproblematiek in de melkveehouderij is urgent. Internationaal gezien moet Nederland wat ammoniakemissie betreft onder het NEC-emissieplafond blijven en op Nationaal niveau moet de depositie op Natura-2000 gebieden de komende decennia sterk verminderen. Om te kunnen blijven ontwikkelen moet de ammoniakuitstoot per dierplaats drastisch terug. Het is beter dit bij de bron aan te pakken om te voorkomen dat er - net als in de intensieve veehouderij - alleen luchtwassers als optie over blijven. Als er geen mestopslag meer toegepast behoeft te worden in de stal (vanwege de snelle afvoer), zal de methaanuitstoot met ongeveer $25 \%$ afnemen. De kosten voor deze wijze van mest verwijderen zullen uiteraard toenemen, echter er zijn ook besparingen mogelijk bij de vloeren en mestkelders.

Als mest en urine apart wordt opgevangen zal de urine dienen als N-meststof op het eigen bedrijf; een deel van de feces kan worden afgevoerd als $\mathrm{P}$ - en organische stof-rijke meststof naar akkerbouwgebieden of (na bewerking) naar het buitenland. Het is te verwachten dat er meer mest vergist of verwerkt zal worden in de komende jaren. Met de feces fractie (veel P) kan in ieder geval de te verwerken hoeveelheid fosfaat worden gestuurd. Het vergisten van verse feces levert een aanzienlijk hogere biogasproductie op dan het vergisten van drijfmest.

\subsection{Doel van de studie}

In deze studie zijn de mogelijkheden verkend om tot een doorbraak te komen in separate opvang en afvoer van feces en urine. Het doel van het project was de urine en de mest gescheiden op te vangen voordat beide fracties op de vloer komen. Het perspectief op een hoge ammoniakemissiereductie is dan het grootst en het vrijkomen van methaan in de stal uit de mest kan vrijwel volledig voorkomen worden. Om dat te bereiken werd gedacht aan oplossingen vanuit de fysiologie, het diergedrag en techniek/automatisering. De studie richtte zich op het verzamelen en ordenen van kennis en creatieve ideeën om via gedrag en/of fysiologie een voorspeller of inductor te kunnen identificeren op grond waarvan het mogelijk is beide mestfracties direct na uitscheiding uit het dier apart op te kunnen vangen. 


\subsection{Indeling rapport}

In hoofdstuk 2 is verslag gedaan van een literatuurstudie naar de fysiologie van de koe aangaande het mesten en urineren en naar het uitscheidingsgedrag. Met deze kennis zijn brainstormsessies gehouden; dit is beschreven in hoofdstuk 3. Uit deze sessies zijn de volgende drie hoofdstukken ontstaan: een pilot-onderzoek om het urineergedrag te trainen (beschreven in hoofdstuk 4), een onderzoek naar het detecteren van urineren en mesten met behulp van staartsensoren (hoofdstuk 5) en onderzoek naar een methode om het urineren op te wekken bij koeien (hoofdstuk 6). Op basis van "trainen/aanleren" en opwekken van urineren is getracht een urineerbox te ontwikkelen (hoofdstuk 7). In hoofdstuk 8 zijn de technische en economische resultaten modelmatig beschreven. Hoofdstuk 9 geeft enkele modelmatige berekeningen weer over de te verwachten emissiereductie. Omdat het stimuleren van urineren aan discussie onderhevig kan zijn, zijn in hoofdstuk 10 enkele maatschappelijke overwegingen gegeven. Hoofdstuk 11 sluit af met discussie, conclusies en aanbevelingen.

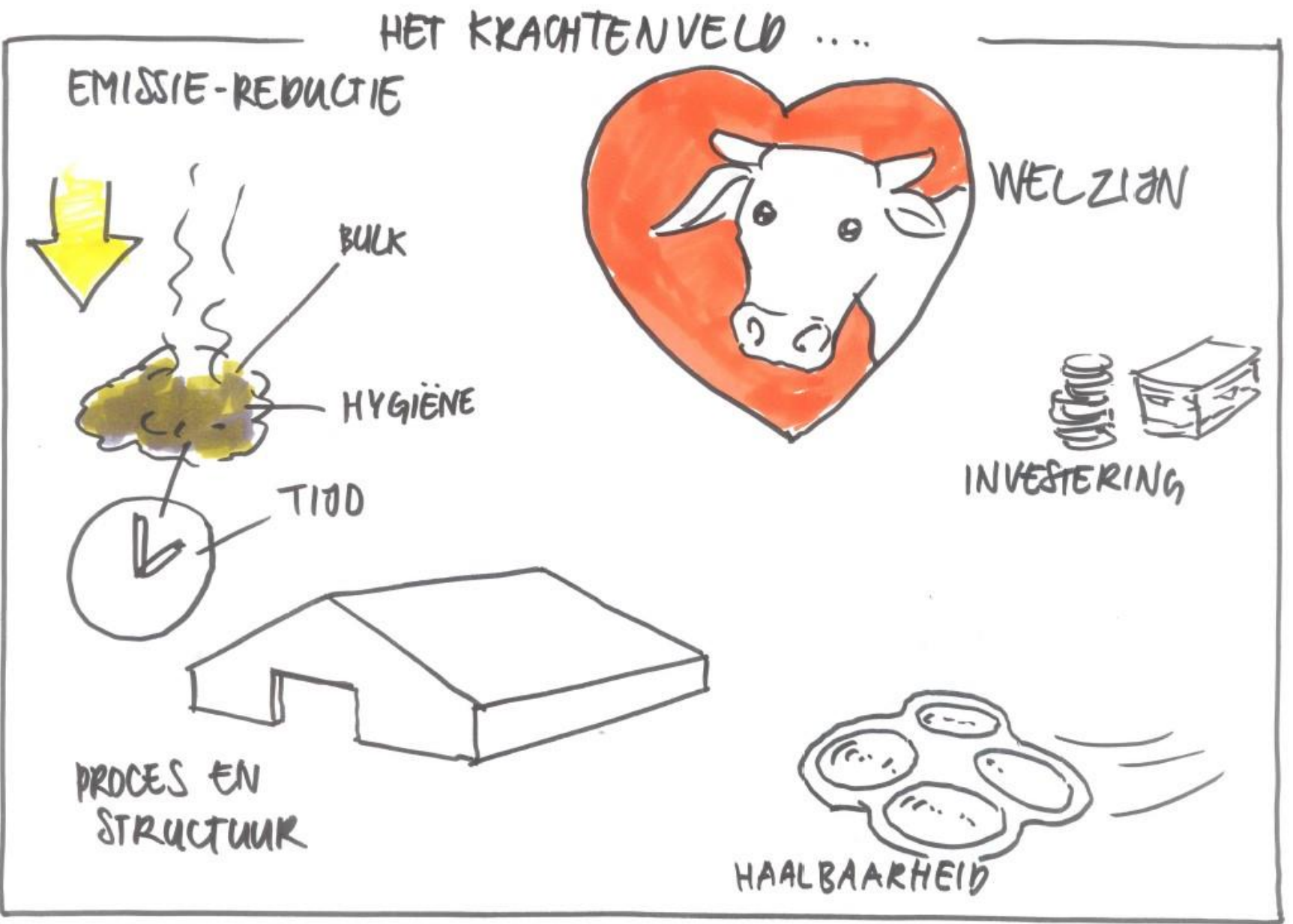




\section{$2 \quad$ Literatuurstudie uitscheidingsgedrag runderen}

Ingrid van Dixhoorn, Wijbrand Ouweltjes, Kees van Reenen, Kathalijne Visser

\section{$2.1 \quad$ Inleiding}

Een belangrijk vraagstuk voor de melkveehouderij is hoe de emissie van ammoniak uit stallen kan worden teruggedrongen. Ammoniak ontstaat zodra mest en urine met elkaar in contact komen, dus het zo snel mogelijk scheiden van mest en urine wordt gezien als een veelbelovende oplossingsrichting. Dit biedt bovendien als voordeel dat meststoffen uit urine en vaste mest gerichter kunnen worden aangewend. Het zo veel mogelijk voorkomen dat mest en urine met elkaar in contact komen heeft de voorkeur boven scheiden door afvoer vanaf de vloer. Om de mogelijkheden hiervoor in kaart te brengen is een literatuurstudie uitgevoerd waarin eerst de kennis omtrent de anatomie en fysiologie van de urinewegen en ontlasting van runderen is geïnventariseerd. Vervolgens zijn ook het natuurlijk gedrag wat betreft uitscheiding van mest en urine, mogelijke beïnvloedende factoren, kennis omtrent het stimuleren en remmen van defecatie en urineren en mogelijkheden voor beïnvloeden van deze activiteiten onderzocht. De bevindingen van dit literatuuronderzoek worden gebruikt voor het bepalen van een vervolgstrategie voor het scheiden van mest en urine.

\subsection{Anatomie en fysiologie}

De urinewegen bestaan uit de nieren, urineleiders, urineblaas en de urinebuis, voor een vrouwelijk rund schematisch weergegeven in Figuur 1.

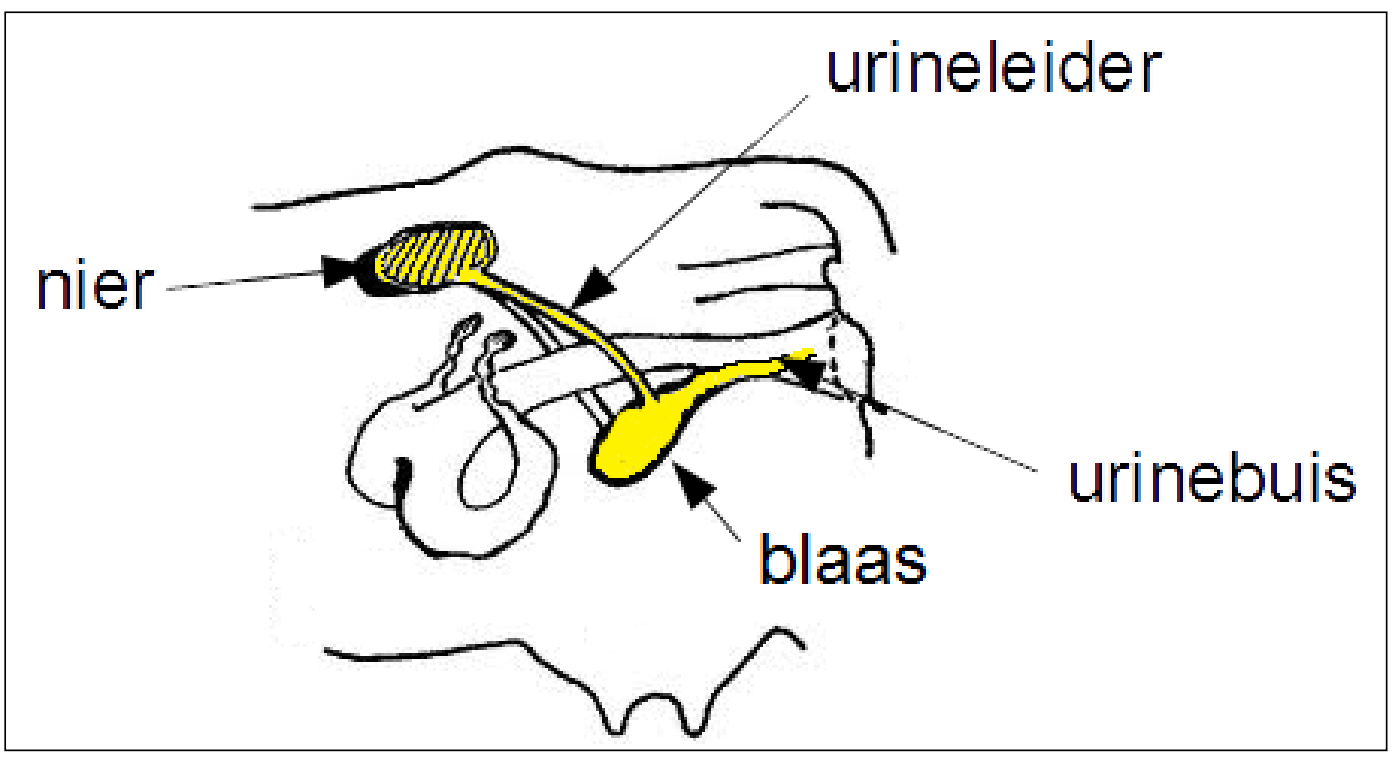

Figuur 1. De urinewegen van het vrouwelijke rund (bron: http://1.bp.blogspot.com/-OEbsfYRv2c/UG4xfKFxqUI/AAAAAAAAAAY/yuenRHU74f8/s1600/t0690e08.gif).

In de nieren wordt het bloed gefilterd en ontdaan van afvalstoffen (Cunningham and Klein, 2007). Dit gebeurt in 2 stappen: eerst wordt een grote hoeveelheid vloeistof met opgeloste stoffen aan het bloed onttrokken (primaire urine), en vervolgens worden allerlei bruikbare stoffen en water terug geresorbeerd en wordt de urine geconcentreerd. De concentratie van de urine wordt mede bepaald 
door hormonale sturing van de werking van de nieren via ADH (antidiuretisch hormoon, gemaakt door hypofyse). De samenstelling van urine is niet gelijk binnen een etmaal, evenals de productie die bij de mens 's ochtends een piek heeft. Meer dan $90 \%$ van de primaire urine wordt normaal gesproken weer geabsorbeerd.

Door samentrekkingsgolven van glad spierweefsel in de wand van de urineleiders wordt urine van nieren naar de blaas getransporteerd (Van Halem and Jungen, 2009). Bij het vollopen van de blaas worden de urineleiders platgedrukt, dit voorkomt dat urine vanuit de blaas terugstroomt naar de nieren. De blaaswand bestaat hoofdzakelijk uit glad spierweefsel (detrusor), met vezels lopend van de top naar de blaasuitgang (overgang naar urinebuis). Bij het begin van de urinebuis is een willekeurige externe kringspier met dwarsgestreept spierweefsel (urethralis), onduidelijk is of er ook een inwendige onwillekeurige kringspier is (Dyce et al., 2010).

In de blaas wordt de urine tijdelijk opgevangen. Naarmate de vulling van de blaas toeneemt worden sensoren in de blaaswand geprikkeld, deze prikkels gaan via het onderste deel van het ruggenmerg naar de blaaswandspier en mogelijk ook de interne kringspier. De blaas trekt samen en de kringspier ontspant, en er gaan signalen vanuit het ruggenmerg naar de hersenschors. Door dit laatste wordt een individu zich bewust van het feit dat de blaas voller wordt en krijgt aandrang om te urineren ("mictiedrang"). Bij dit hele proces zijn zowel het somatische, sympatische en parasympathische deel van het zenuwstelsel betrokken. Schematisch is het mechanisme weergegeven in Figuur 2 (gekopieerd uit Van Halem and Jungen (2009).

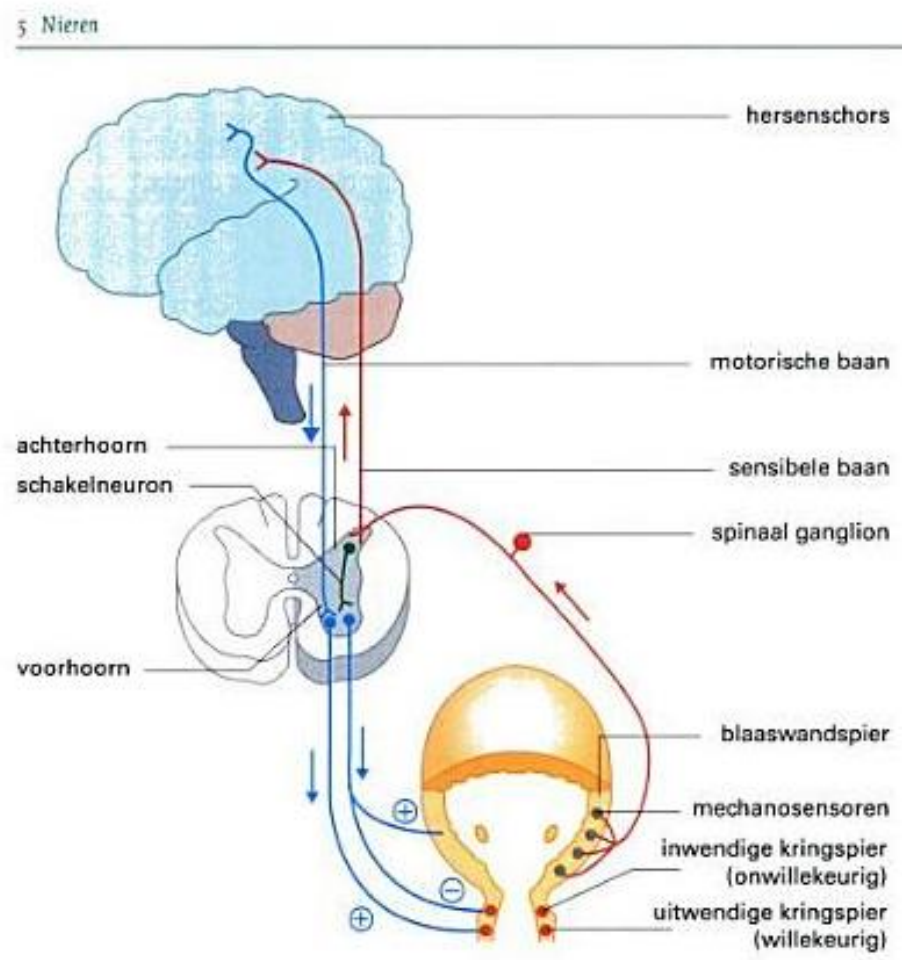

Figur 2. Blaasreflexmechanisme (bron: Van Halem and Jungen (2009).

De mate van vulling van de blaas waarbij aandrang tot urineren optreedt is (bij de mens) mede afhankelijk van temperatuur (bij sterke kou eerder aandrang), emoties, inspanning/afleiding. Volgens Birder et al. (2014) spelen ook signalen vanuit de urinebuis een rol. Met de uitwendige sluitspier kan de mictiedrang al dan niet tijdelijk worden onderdrukt. Zodra prikkels uit de hersenschors de externe kringspier ook ontspannen volgt een urinelozing. De urinelozing kan worden bevorderd door via samentrekking van buikspieren de druk op de blaas te verhogen. Normaal gesproken is de blaas na het urineren leeg als de lozing niet wordt onderbroken. Het feit dat ook runderen een dwarsgestreepte externe kringspier hebben betekent in principe dat ze controle over het lozen van urine hebben. Bij mensenbabies en jonge katten en honden werkt de bewuste controle van de uitwendige kringspier vlak na de geboorte nog niet, daarom worden ze pas later zindelijk. Mogelijk geldt dat ook voor jonge kalveren. 
Via de anus verlaten onverteerd voedsel en afvalstoffen het maagdarmkanaal. Het overgrote deel van de tijd is de anus gesloten door een inwendige onwillekeurige sluitspier (verdikt glad spierweefsel van het darmkanaal) en een uitwendige willekeurige sluitspier (gestreept, somatische oorsprong), en is de wand van de endeldarm ontspannen. De interne sluitspier wordt door zowel sympathische als parasympatische zenuwen beïnvloed. Wanneer als gevolg van darmperistaltiek ontlasting de endeldarm wordt binnengeduwd treedt de defecatiereflex ("rectosphinxteric reflex") op, die gepaard gaat met een drang tot ontlasten. Voor de mens wordt gesteld dat de contracties waarbij ontlasting de endeldarm in wordt gedrukt slechts enkele keren per dag optreden, vooral na opstaan en maaltijden. Peristaltische contracties komen in de dikke darm veel minder voor dan ringvormige zich niet of nauwelijks voorkomende contracties, en als ze voorkomen vooral bij ontwaken, na voedselinname en bij bewegen.

De defecatiereflex vertoont overeenkomsten met de mictiereflex, en heeft tot gevolg dat de inwendige anale sluitspier wordt ontspannen en de rectumwand wordt aangespannen. Defecatie wordt dan voorkomen door bewust aanspannen van de uitwendige sluitspier. Als aan de aandrang wordt toegegeven dan treedt normaal gesproken een scala aan veranderingen op: verhoging van de druk in de buikholte door spiersamentrekking, ontspanning van de anus en spieren van de bekkenbodem, houdingsverandering. Deze veranderingen dragen bij aan het legen van de endeldarm. Voor de mens is vermeld dat de vorm van de inhoud (gas, vloeistof, vast) mede bepaalt hoe strak de uitwendige sluitspier is gespannen. Bij vloeibare inhoud is deze spier strak gespannen en kan de aandrang minder goed worden onderdrukt dan bij meer vaste inhoud. Net als bij urineren kunnen jonge kinderen de uitwendige anale sluitspier nog niet onder controle houden.

De zogenaamde nucleus van Onuf is een gebied in het ruggenmerg van waaruit zowel de anale als urethrale sluitspieren worden aangestuurd. Deze zijn daardoor mogelijk niet geheel onafhankelijk van elkaar, voor de mens geldt dat beide spieren tijdens ontlasten verslappen. Hierdoor vinden ontlasten en urineren vaak samen plaats. Voor runderen vonden Villettaz Robichaud et al. (2011) een positief verband tussen de mest- en urineerfrequenties van runderen, maar er werd niet gerapporteerd in welke mate beide tegelijkertijd optraden.

\subsection{Natuurlijk uitscheidingsgedrag van runderen}

Verschillende onderzoeken bij runderen lieten een grote individuele variatie zien in frequenties van mesten en urineren (Aland et al., 2002; Hirata et al., 2011; Vaughan et al., 2014b; Villettaz Robichaud et al., 2011). Er blijkt geen duidelijk verband te zijn tussen het aantal mest- en urinelozingen per dier (Aland et al., 2002), en zowel dat onderzoek als dat van (Villettaz Robichaud et al., 2011) geven aan dat het aantal lozingen niet samenhangt met melkproductie. Voor het aantal keren mesten per dag zijn gemiddelden gerapporteerd tussen 10 en 16 keer; dagelijkse gemiddelden voor het aantal keren urineren per dag van melkkoeien liggen in de orde van grootte van 7 tot 9 keer. De range voor de dagelijkse frequentie mesten loopt van 3 tot 36 keer; die voor de dagelijkse frequentie urineren van 2 tot 19 keer (Aland et al., 2002; Villettaz Robichaud et al., 2011). Volgens Hirata et al. (2011) is de hoeveelheid mest per defecatie groter wanneer dieren rusten of herkauwen dan wanneer ze grazen en zich verplaatsen. Alle onderzoeken waarin zowel het aantal defecaties als het aantal urinelozingen van melkkoeien is gescoord laten zien dat vaker gemest dan geürineerd wordt (Aland et al., 2002; Hirata et al., 2011; Oudshoorn et al., 2008; Villettaz Robichaud et al., 2011).

In enkele studies is gerapporteerd dat koeien op stal soms liggend defeceren (Aland et al., 2002; ten Haaf and van der Linde, 2013; Villettaz Robichaud et al., 2011; Whistance et al., 2007), waarbij alleen Villettaz Robichaud et al. (2011) percentages noemt: 4.7 - 8.2\% van de defecaties. In dat laatste onderzoek werden in een ligboxenstal vaker defecaties gezien van liggende dieren dan in een potstal. In het onderzoek van (Whistance et al., 2011) met koeien in de weide werden geen defecaties gezien van liggende dieren, als ze lagen kort voordat ze gingen defeceren stonden ze eerst op. Ook defeceren tijdens lopen is waargenomen, zowel in de weide (Oudshoorn et al., 2008) als in de stal (Whistance et al., 2007). Het merendeel van de defecaties gebeurt echter terwijl koeien stil staan (Whistance et al., 2007). Urineren gebeurt vrijwel uitsluitend terwijl de dieren staan (Aland et al., 2002; ten Haaf and 
van der Linde, 2013; Villettaz Robichaud et al., 2011). (Aland et al., 2002; ten Haaf and van der Linde, 2013; Villettaz Robichaud et al., 2011). (Vaughan et al., 2014b) hebben bij kalveren geen liggende dieren zien defeceren of urineren.

Een andere belangrijke waarneming die in verschillende studies naar voren komt is dat koeien wel gedrag vertonen waaruit geconcludeerd kan worden dat ze verse mest vermijden. Het karakteristieke gedragspatroon van koeien in de wei na afloop van defeceren bestaat eruit dat de dieren direct van de vers gedeponeerde mestflat in voorwaartse richting weglopen. Daarmee wordt actief de kans op bevuiling verkleind (Whistance et al., 2007; Whistance et al., 2011). Er lijkt een duidelijk patroon te zijn in de volgorde van liggen, opstaan om te mesten/te urineren, te lopen of te liggen. In potstallen komt het patroon van liggen, opstaan, mesten, stukje lopen en weer gaan liggen en het patroon van lopen, stilstaan om te mesten en verder lopen significant meer voor vergelijking met ligboxenstallen. Er wordt dan ook geconcludeerd dat het hebben van meer comfort (in de stal met stro) ertoe bijdraagt dat de koeien makkelijker opstaan en een natuurlijk gedragspatroon voor wat betreft mesten kunnen vertonen (Whistance et al., 2007). Door deze onderzoekers wordt geopperd dat wanneer een koe makkelijker, met meer comfort, kan opstaan en kan gaan liggen, ze dit meer frequent over de dag zal doen en vaker de ligplaats zal verlaten om te eten, waardoor de kans kleiner is dat ze direct na het opstaan moet mesten.

Wanneer een koe aandrang heeft om te mesten is heel duidelijk een verandering te zien in haar houding: het lichaam wordt licht naar achteren gekanteld, de staart gaat omhoog, en de rug licht gebogen. Voor urineren geldt bijna hetzelfde, behalve dat dan de rug sterker gebogen is en de achterpoten iets meer naar voren en uit elkaar staan (Aland et al., 2002). Deze houdingsverandering doet zich echter pas vlak voor het mesten/urineren voor, dus kan niet als een relevante voorspeller gebruikt worden. Deze kennis wordt wel toegepast bij de koe-trainer, waarbij vooral het krommen van de rug op bepaalde plaatsen in de stal wordt ontmoedigd doordat het dier dan een elektrische schok krijgt (Bergsten and Pettersson, 1992; Oltenacu et al., 1998).

Orr et al.(2012) vonden in een onderzoek bij runderen in een semi-natuurlijk weidegebied dat urineren en mesten in zekere mate gesynchroniseerd waren in de tijd, waarbij de ene vorm van uitscheidingsgedrag kort daarop werd gevolgd door de andere vorm van uitscheidingsgedrag. Welke vorm van uitscheidingsgedrag - urineren of mesten - het eerste plaatsvond was daarbij door toeval bepaald. Een dergelijke synchronisatie werd niet gevonden door Hirata and Higashiyama (1997) bij 'Japanese Black cattle' die overdag werden geweid en 's nachts binnen stonden: hier bleek dat mesten bij voorkeur plaatsvond op de weide, en urineren met name op het looppad van de weide naar de stal.

De meeste beschrijvende studies van het uitscheidingsgedrag van runderen laten zien dat er sprake is van een bepaald patroon in de tijd, over de dag. Over het algemeen wordt de hoogste frequentie van mesten en urineren waargenomen tijdens periodes dat de dieren actief zijn, dus tijdens grazen (voor runderen in de weide), voeropname aan het voerhek of bij een voerautomaat, en melken ((Aland et al., 2002; Hirata et al., 2011; Marcillac-Embertson et al., 2009; Vaughan et al., 2014b). In één studie bij een groep melkkoeien in een ligboxenstal was de frequentie van het uitscheidingsgedrag min of meer willekeurig verdeeld over de dag (Villettaz Robichaud et al., 2011).

Naast de factor tijd is ook de factor plaats van invloed op de frequentie van uitscheidingsgedrag van runderen. Een nog niet goed begrepen waarneming bij koeien in een 'free range' systeem (met toegang tot een rivier) was dat koeien in de rivier een vijf keer hogere frequentie van mesten lieten zien dan daarbuiten (Bond et al., 2012). In de weide is de plek van de waterbak in belangrijke mate bepalend voor de frequentie van mesten en urineren, en een belangrijk oriëntatiepunt waarmee de ruimtelijke verdeling van mest en urine kan worden gestuurd. Rond dit punt worden hoge frequenties mesten en urineren gezien (Auerswald et al., 2010; White et al., 2001). Hekwerk kan de frequentie van uitscheidingsgedrag op bepaalde plaatsen in de weide juist verlagen (Auerswald et al., 2010), maar waarschijnlijk is dat veroorzaakt doordat de dieren 's nachts rustten op plaatsen die wat verwijderd waren van de perceelsgrenzen. 


\subsection{Bevorderende en remmende/ uitstellende factoren voor mesten/ urineren}

Tot op heden is er weinig bekend over de factoren die mesten/urineren beïnvloeden, behalve dan de fysiologische route waarbij vulling van de blaas en dikke darm uiteindelijk redenen zijn voor de koe om te urineren of te mesten. Voor wat betreft huisvesting zou de ondergrond een beïnvloedende factor kunnen zijn, maar er zijn geen referenties gevonden die dit onderbouwen. Waarschijnlijk speelt vooral een rol dat runderen wel een voorkeur hebben voor plaatsen om te verblijven, met als gevolg dat ze daar waar ze langer verblijven ook meer mest en urine deponeren. In de wei zoeken koeien bijvoorbeeld droge plekken op om te liggen, daar wordt daarom ook meer gemest en geürineerd (Sjaak Sprangers, 2015, persoonlijke mededeling). In enkele onderzoeken is gekeken naar de frequentie van urineren en mesten in verschillende delen van stallen. In een studie van Whistance et al. (2007) werd aangetoond dat koeien in een potstal weliswaar meer mesten op de ligplaatsen met stro dan op de betonvloer in die stal, maar wanneer dat werd omgerekend naar vierkante meters, dan bleek dat er significant meer mest lag op de betonnen paden in vergelijking met de plaatsen waar stro lag. Ook Vaughan et al. (2014a) vonden verschillen tussen delen van de stal in de frequentie van mesten en urineren voor kalveren die waarschijnlijk veroorzaakt werden doordat de dieren niet overal even veel verbleven. Geen van deze studies geeft aanwijzingen dat runderen bij voorkeur hebben om op een bepaalde ondergrond te urineren of te mesten.

Voor wat betreft het dagritme is in meerdere studies aangetoond, dat koeien vooral mesten en urineren vlak nadat ze zijn opgestaan en tijdens en na vreten en drinken (Aland et al., 2002; Villettaz Robichaud et al., 2011). Aland et al.(2002) geven geen interval tussen opstaan en defeceren, maar vonden dat $95 \%$ van de geobserveerde dieren na een langere ligbout defeceerde of urineerde en $60 \%$ deed dat tijdens of kort na te hebben gevreten of gedronken. $10 \%$ van de dieren mestte soms al tijdens het opstaan. Villettaz Robichaud et al. (2011) vonden dat $12.6 \%$ van de defecaties en $21.4 \%$ van de urinelozingen binnen 3 minuten na opstaan plaatsvonden. Tijdens en na eten zijn de koeien meer in beweging wat het mesten en urineren waarschijnlijk stimuleert (Hirata et al., 2011). Ook wanneer koeien in een nieuwe omgeving komen of (tijdelijk) sociaal geïsoleerd worden van hun soortgenoten ligt de frequentie van mesten en urineren significant hoger, dit werd aangetoond in een studie van Rushen et al. (2001) waarin koeien wel of niet in een geïsoleerde ruimte werden gemolken. $\mathrm{Er}$ is geen onderzoek gevonden waarin onderzocht is wat de invloed van de melkmethode (conventioneel of automatisch) of de melkfrequentie is op het aantal keren mesten of urineren. Omdat 3* daags melken een hogere melkgift en hogere voeropname veroorzaakt (Beerda et al., 2007) en meer koppelsgewijze activiteit momenten meebrengt, kan worden verondersteld dat het aantal lozingen iets toe kan nemen. Automatisch melken kan enerzijds meer rust brengen, maar kan ook de synchroniciteit van de koppel verstoren. De melkfrequentie bij automatisch melken hangt mede af van de robotbezetting en het koeverkeer. Waarschijnlijk speelt naast het melken ook de manier van voerverstrekking een rol, waardoor het niet duidelijk is wat het effect van automatisch melken op mesten en urineren is.

Samenstelling van de groep en de manier van omgang met de koeien zijn ook van invloed op de frequentie van urineren en mesten. In de studie van Aland et al. (2002) bleek dat er overdag meer werd gemest en geürineerd omdat de dieren dan meer in contact waren en meer gestoord werden door andere dieren dan gedurende de nacht. In een studie van Munksgaard et al.(1997) bleek dat dieren die aversief werden behandeld meer mesten en urineerden in vergelijking met dieren die meer gemoedelijker werden behandeld. Het onderzoek van Rushen et al. (2001) liet zien dat koeien die in een hen onbekende ruimte werden gemolken maar werden geborsteld door een bekende persoon in tegenstelling tot koeien waarbij geen bekend persoon in de buurt was, niet vaker defeceerden of urineerden dan koeien die in een bekende ruimte werden gemolken. Waarschijnlijk kan een persoon rust brengen en is er niet zo zeer sprake van dat daarmee uitstel van urineren of defeceren wordt bewerkstelligd (dat zou het geval zijn als de uitscheiding bij niet gestreste dieren zou worden beïnvloed). Gesuggereerd is dat koeien meer uitscheidingsgedrag uitvoeren wanneer ze onder een koeborstel staan of comfortgedrag uitvoeren. Hierover is in de literatuur geen informatie te vinden, maar als dat al het geval is dan hangt dat waarschijnlijk samen met de momenten wanneer de koeborstel gebruikt wordt. 


\subsection{Opwekken van uitscheidingsgedrag}

Bij runderen vonden Aland et al. (2002) dat ze tijdens melken en voeren relatief vaak urineerden en mestten, wellicht stimuleren deze activiteiten de excretie. Kumar et al. (2006) betogen dat zogen het urineren stimuleert. Hirata et al. (2011) vonden een tendens van hogere urineer- en mestfrequenties overdag dan 's nachts voor grazende koeien, en vaker urineren en mesten voor koeien die minder lagen en herkauwden. Zij opperen dat locomotie stimulerend werkt op mesten en urineren. Voor de mens wordt gesteld dat beweging de stoelgang bevordert. Villettaz Robichaud et al. (2011) vonden echter geen diurnale ritmes in mesten en urineren. Ook stress stimuleert mesten en urineren, blijkt uit een studie van Rushen et al. (2001). Voor de mens wordt beweerd dat de hand in warm water dompelen de drang om te urineren stimuleert, net als het geluid van stromend water. Robichaud et al. (2013) onderzochten of geleid worden door een voetbad gevuld met water van $21^{\circ} \mathrm{C}$, stromend water of een luchtstroom op de klauwen stimulerend werkten op mesten. Als de proefdieren iets nieuws meemaakten leek dat wel stimulerend te werken, maar de toegepaste behandelingen hadden geen blijvend effect. Verder heeft bijvoorbeeld koffie een stimulerend effect (Cho et al., 2014). Ook vocht afdrijvende middelen die invloed hebben op de ionenhuishouding in de nieren (diuretica), zoals bijvoorbeeld furosemide, kunnen het urineren stimuleren. Ze verhinderen de heropname van natriumen chloride-ionen in het bloed na de eerste filtratiestap in de nieren en verminderen de heropname van calcium en magnesium. Dit heeft tot gevolg dat er meer vloeistof naar de urineblaas stroomt, en de blaas dus sneller vol raakt. Kort na intraveneuze toediening komt de urinelozing op gang (Nervig and Garrett, 1979).

Voor onderzoek of diagnostiek moeten soms ook mest- en urinemonsters genomen worden. Er zijn verschillende technieken ontwikkeld om mest en urine gescheiden op te vangen (Cao et al., 2009; Kurien et al., 2004; Lascano et al., 2010; Van Es and Vogt, 1959), waarbij meestal gebruik wordt gemaakt van spontane lozingen door de dieren. Alleen Kurien et al. (2004) en Northway (1975) bespreken methodes om een urinelozing op te wekken. Voor runderen bleek opvoelen van het rectum effectief (Northway, 1975). Verder wordt handmatige stimulatie van het perineum regelmatig gebruikt om urinelozing op te wekken in onderzoek met runderen (Kumar et al., 2000; Roche et al., 2007), maar deze artikelen geven behalve dat er enkele gevallen waren waarin geen monster werd verkregen geen nadere informatie over deze methode. Het huidgedeelte wat hierbij wordt gestimuleerd wordt goed geïnnerveerd door de oppervlakkige sensibele tak van de nervus pudendus, deze tak innerveert ook de huid rond de anus en vulva. De diepe sensorische tak van de N. pudendus innerveert het rectum en de in- en externe voortplantingsorganen en loopt door tot het achterste huidgedeelte van het uier. De motorische tak van dezelfde zenuw zorgt voor aansturing van de (dwarsgestreepte, willekeurige) spieren in het perineale gebied (o.a. de sluitspier van de blaas) (Dyce et al., 2010). Waarschijnlijk kan daarom prikkeling van deze zenuw, door stimulatie van het gebied, de oorzaak zijn voor het ontspannen van de willekeurige sluitspier van de blaas. Mogelijk dat er ook een link is met seksuele stimulatie, door bijvoorbeeld een stier, gezien het totale gebied dat de zenuw innerveert, maar onderbouwing hiervoor is niet gevonden. Verwacht wordt dat tijdens de oestrus een negatieve terugkoppeling bestaat tussen aanraking van het perineum en urineren, om te voorkomen dat urine zich mengt met sperma (Dr. Claudia Wolschrijn, 2015, persoonlijke mededeling). Mogelijk is de frequentie van urineren verhoogd tijdens oestrus, maar daarvoor zijn geen goede aanwijzingen gevonden. Uit onderzoek van Metz (Metz \& Metz, 1986) bleek dat likken van het kalf door de koe in de anogenitale zone pasgeboren kalveren stimuleerde om te mesten en te urineren. Opvallend was dat bij stierkalveren de eerste urinelozing later kwam dan de eerste darmlozing, bij vaarskalveren kwamen beide ongeveer tegelijkertijd. Onduidelijk is of het likken van het kalf door de koe in de anogenitale zone deels een vergelijkbaar fysiologisch effect heeft als manuele stimulatie van het perineum, maar dat lijkt wel logisch gezien de innervatie.

In het algemeen wordt aangenomen dat runderen niet zindelijk zijn, wat zou betekenen dat ze niet in staat zijn om de prikkel om te urineren of defeceren te beheersen. Gezien de anatomie en fysiologie van beide processen is dat echter niet waarschijnlijk, zowel de externe anale sluitspier als de externe sluitspier van de urinebuis worden door het somatische deel van het zenuwstelsel aangestuurd. Uit het onderzoek van Whistance et al. (2007) bleek dat melkkoeien in een potstal contact met hun eigen mest in zekere mate proberen te voorkomen. Ook in de weide blijken ze dergelijk gedrag te vertonen 
(Whistance et al., 2011) en aangevoerd wordt dat ook de lichaamshouding tijdens het mesten/urineren is gericht op vermijden van besmeuring, maar uit het onderzoek van Oudshoorn et al. (2008) bij beperkt weiden bleek dat de mest en urine over het hele oppervlak verdeeld werden geloosd. In een ligboxenstal is dat volgens het onderzoek van Whistance et al. (2007) veel minder het geval.

\subsection{Sturen van uitscheidingsgedrag van runderen}

In enkele studies is onderzocht of runderen getraind kunnen worden om op specifieke plaatsen te mesten of urineren. Volgens Wechsler and Lea (2007) hebben landbouwhuisdieren in het algemeen een goed ruimtelijk geheugen, en kunnen leren zich aan te passen. Bij ongewenst gebruik van de stalruimte kan dat mogelijk worden geweten aan ontwerpfouten. Lang geleden is door Brantas (1968) al een aanzet gedaan voor beïnvloeding van mest- en urineergedrag. Hij onderzocht of het mogelijk was om zo veel mogelijk mest in een mestgoot op te vangen. De dieren stonden daarbij tijdens vreetbeurten enige tijd vast aan een voerhek, het leerproces had met name betrekking op de routing in de stal van ligplaats naar vreetplek en melkstal en op het gebruik van de vreetplekken. Jongere dieren bleken makkelijker te leren dan oudere, maar niet duidelijk was wat daarvan de oorzaak was. Relatief veel mest kon in de mestgoot worden opgevangen door bij de timing van voerverstrekking in te spelen op het normale uitscheidingsgedrag. Whistance et al. (2009) gebruikten clicker training en krachtvoer als beloning om dieren te leren op beton in plaats van in stro te mesten en urineren. De dieren konden zich aan het eind van de training vrij door de stal bewegen en urineren en mesten gebeurde spontaan. In dat onderzoek was het succes van de training beperkt; de mate waarin dieren die zich in het stro bevonden voor mesten of urineren naar het beton gingen nam niet toe en de mate waarin ze zich van het beton naar het stro verplaatsten nam niet af. Wel bleek uit het onderzoek dat runderen zich inderdaad bewust zijn van het mesten en urineren. Vermoed wordt dat het voor de proefdieren niet voldoende duidelijk was waarvoor ze beloond werden (het onderscheid tussen de ligruimte en de betonvloer was mogelijk onvoldoende duidelijk), onwaarschijnlijk is dat ze niet in staat zijn om de aandrang tijdelijk te onderdrukken. Vaughan et al. (2014a) gebruikten 2 vormen van conditionering om kalveren te trainen bij urineren: operant of klassiek. Deze onderzoekers concluderen dat operant conditioneren mogelijk bruikbaar is om runderen te trainen in bepaalde delen van de stal te urineren. Klassiek conditioneren (toedienen van diureticum bij vastzetten in een box) werkte niet goed. In feite komt deze training er op neer dat door het opbouwen van een associatie tussen urineren en een beloning het blaasreflexiemechanisme wordt getriggerd. Door Wredle et al. (2006) is onderzocht of koeien met een geluidssignaal gestimuleerd kunnen worden om na een bepaald tijdsinterval een melkrobot te bezoeken, en dat blijkt in zekere mate mogelijk. De verschillende onderzoeken geven aan dat er mogelijkheden zijn om koeien te trainen en te sturen, maar het vergt meer onderzoek om te bepalen hoe en op welke leeftijd dit het beste kan worden gedaan.

Naast sturen van gedrag door leren kan ook worden gestuurd door inrichting van de leefruimte. Zo hebben Aland et al. (2009) vastgesteld dat bij aangebonden koeien ligplaatsafscheidingen tussen dierplaatsen zorgen voor minder mest en urine op de naastgelegen plaatsen. Elektrische koetrainers blijken effectief te zijn om vervuiling van ligboxen tegen te gaan, maar hebben nogal wat nadelen voor de gezondheid van de dieren (Oltenacu et al., 1998). Ligboxen zijn ontworpen om te voorkomen dat runderen hun ligplaatsen bevuilen. Ruud et al. (2011) hebben het verband tussen kenmerken van ligplaatsen en hygiëne onderzocht, en vonden een aantal ligplaatskenmerken die samenhingen met de box hygiëne. Fregonesi et al. (2009) vonden dat naar voren plaatsen van de schoftboom in ligboxen gepaard ging met meer mesten en urineren op de ligplaats.

Een aantal onderzoeken is gericht op het sturen van dieren door middel van virtual fences (BishopHurley et al., 2007; Lee et al., 2009; Lee et al., 2007; Umstatter, 2011). Van belang is dat dier snapt wat het gewenste gedrag is, ofwel wat het zou moeten doen om een negatieve prikkel te ontlopen (associative learning) (Lee et al., 2007; Umstatter, 2011). Volgens ander onderzoek (Lee et al., 2008) is de negatieve impact van elektrische schokken voor de dieren gering, en vergelijkbaar met even vastzetten in een box. Het blijkt dat runderen met audiosignalen binnen virtuele omheiningen gehouden kunnen worden (Lee et al., 2009). Wellicht zijn er mogelijkheden voor sturen van uitscheidingsgedrag met dergelijke techniek. 


\section{Creatieve sessies}

Nico Verdoes en Bram Bos

\section{$3.1 \quad$ Opzet}

In de vooraf uitgevoerde literatuurstudie (hoofdstuk 2) is het diergedrag, dierfysiologie, leergedrag van koeien, opwekken en voorspellen van gedrag m.b.t. urineren en mesten in kaart gebracht. Daarbij waren de volgende vragen leidend:

- Kan mest- en/of urineergedrag (in plaats of tijd) worden voorspeld?

- Kan mest- en/of urineergedrag worden opgewekt?

- Kan mest- en/of urineergedrag (in plek of tijd) worden aangeleerd? En in welke leeftijdsfase?

- Wat zijn eventuele ongewenste bijeffecten van opwekken dan wel aanleren, bijvoorbeeld voor welzijn en gezondheid van de koeien?

In twee creatieve sessies in het najaar van 2014 zijn de mogelijkheden onderzocht om met behulp van het (eventueel aangeleerd) gedrag van melkvee primaire scheiding van mest en urine in

melkveesystemen te realiseren, met het oog op reductie van ammoniakemissie en betere verwaarding van mineralen. De deelnemers staan vermeld in bijlage 1.

De doelstelling was:

1. Presenteren, toetsen, aanvullen en verrijken van de resultaten van de uitgevoerde literatuurstudie (sessie 1). Vanuit wetenschappelijk domein, en liefst ook vanuit de praktijk (veehouders of dierenartsen met een observerend oog op diergedrag) aanvullen van kennis en inzicht.

2. Waar nodig en mogelijk verder hanteerbaar maken van die kennis (van observaties naar capaciteiten voor de mogelijke gewenste functies in het systeem)

- T.b.v. overdracht naar bedrijfsleven in sessie 2

- T.b.v. identificeren van Hoe Kunnen We (HKW)-vragen, die we kunnen gebruiken voor de (creatieve) identificatie van nieuwe producten

3. Identificatie en eerste ontwikkeling van productideeën, waarmee (participerend) bedrijfsleven aan de slag kan. Vaststelling IP-waardige ideeën; vaststelling van wat vertrouwelijk blijft. Bepalen welke pilots we gaan onderzoeken en welk bedrijf daarin participeert.

De creatieve sessie bestond uit twee dagen, waarvan de eerste gericht was op het gezamenlijk begrijpen van de opgedane kennis in de literatuurstudie en het vervolgens verkennen van de functionele mogelijkheden die deze kennis biedt om nieuwe wegen in te slaan in het gescheiden houden van mest en urine. Deze functionele mogelijkheden werden vervolgens in de tweede creatieve sessie uitgewerkt naar concrete uitwerkingen voor product-ideeën. Drie van de vier uitwerkingen zijn vervolgens in het project verder ter hand genomen en doorontwikkeld.

De gehanteerde methodiek tijdens de creatieve sessies was een mengvorm van klassieke creatieve facilitatie (met divergentie en convergentie rond een specifieke (HKW-)vraag), het structureren van gezamenlijke analyse en het in groepen uitwerken van kansrijke ideeën. Speciale aandacht werd besteed aan de diversiteit aan deelnemers. 


\subsection{Resultaten}

\subsubsection{Functionele mogelijkheden}

Uit de eerste creatieve sessie kwamen de volgende twee belangrijke functionele mogelijkheden naar voren:

Diergedrag is bepalend, urineren op plaats waar de koe wil; stalontwerp en techniek moet hierop aangepast worden

Koeien lopen normaal gesproken niet achteruit na mesten en urineren. Ze mesten weleens lopend; urineren alleen stilstaand. Als koeien opstaan in de box mesten en urineren ze vaak net achter de box en worden dan gedwongen om achteruit door de mest heen te lopen. In het stalontwerp kunnen we hier rekening mee houden. Dieren staan op, box blijft gesloten, ze moeten eerst mesten en/of urineren. Dat wordt apart opgevangen. Vervolgens mogen ze vooruit de box verlaten. Hier worden koeien niet gestimuleerd om te urineren op een bepaalde plek, maar wordt meer gebruik gemaakt van het natuurlijk gedrag van urineren na opstaan. Hieruit is de HKW gedestilleerd: Hoe kunnen we zoveel mogelijk mest en urine gescheiden opvangen binnen 3 minuten nadat zij gaat staan en dat gescheiden afvoeren?

Diergedrag wordt gestuurd; urineren op (kleine) plaats die wij willen

Urine wordt opgevangen in een soort urinoir. De dieren worden gestimuleerd hiernaar toe te gaan. Cruciaal is of ze het een bepaalde tijd "op kunnen houden". In het urinoir worden ze indien nodig gestimuleerd door massage onder de kling of via geluid, of via een beloning met voer of een vorm van training. Het urinoir zou een soort urineerbox kunnen zijn of een inwendige rivier in de stal (watergeluidjes). Of een kunststier die in de box de koe stimuleert tot urineren. Hieruit is de HKW gedestilleerd: Hoe kunnen we koeien (+jongvee) kenbaar laten maken dat zij gaan mesten of urineren?

\subsubsection{Uitwerkingen}

In de tweede sessie is gewerkt aan concrete uitwerkingen die een van beide functionele mogelijkheden benutten. Na een divergentie-ronde, waaruit een veelheid van ideeën werd geoogst, werden de beste ideeën geselecteerd aan de hand van de zogeheten 'COCD-box' (Centrum voor de Ontwikkeling van het Creatief Denken):

Blauw = gewone ideeën, realiseerbaar $=$ NOW

Rood $=$ originele ideeën, realiseerbaar $=$ WOW

Geel $=$ originele ideeën, (nog) niet realiseerbaar $=$ HOW

Deze selectieronde resulteerde in 4 WOW-sporen die vervolgens verder werden uitgewerkt.

\section{UITWERKING 1 - Opstaan en opvangen}

De koe mest en/of urineert vaak als ze opstaat uit de ligbox. Om de mest en urine op te vangen na het opstaan zijn er verschillende mogelijkheden. Deze worden hier verder niet uitgewerkt. Omdat UITWERKING 2 dan eerst bekend moet zijn, is UITWERKING 1 in de planning naar achter geschoven.

\section{UITWERKING 2 - Big data}

Des te meer data worden verzameld des te beter waarschijnlijk voorspeld kan worden of een koe na het opstaan gaat mesten dan wel urineren. In ieder geval is een signaal nodig dat een dier opstaat, en daarmee samenhangend een sensor die monitort wanneer dieren liggen dan wel staan. Wellicht is ook van belang of het dier voor het opstaan aan het herkauwen was, en wanneer ze heeft gevreten en gedronken. Daarnaast kan het nodig zijn om te weten waar het dier zich in de stal bevindt. Voor al deze signalen geldt dat er al sensoren bestaan. Verder vermoeden we dat met name het interval sinds de laatste lozing van mest en urine voorspellend is voor de mate van blaas- en darmvulling. Daarbij moet rekening worden gehouden met individuele variatie. Dus ook het vastleggen van tijdstippen van mest- en urinelozingen van individuele dieren lijkt een nuttige bron van informatie. Wellicht is het ook 
mogelijk om meer rechtstreeks blaas- en darmvulling vast te stellen. Voor praktische toepassing is van belang dat de gegevens real time beschikbaar komen. Dit komt aan de orde in hoofdstuk 5 .

\section{UITWERKING 3 - Urineerbox}

Er zijn al krachtvoerboxen. Een dergelijke box is uit te breiden met een urinelozing-stimulus en ook met urine-opvangmogelijkheden. De box wordt van achteren afgesloten als een koe erin staat. De urine wordt opgevangen. Als de koe geürineerd heeft krijgt ze een beloning. Er is enige afbakening gewenst:

- Gestart wordt met de opvang van de urine; opvang van feces in een later stadium.

- $\quad$ Later kunnen sensoren die mesten/urineren voorspellen ingebouwd worden.

- Alleen een urineerbox is wellicht niet voldoende; ook bij de ligplek of bij het voerhek zullen opvangmogelijkheden moeten komen.

- $\quad$ Een urineerbox kan in de jongveeopfok ook een plaats krijgen, zodat de dieren er alvast aan wennen of getraind worden erin te plassen.

- $\quad$ De box toepassen bij weidegang is een grote uitdaging.

Deze optie wordt verder beschreven in hoofdstuk 7.

\section{UITWERKING 4 - Trainen van koeien}

Het lijkt zinvol een leerexperiment op te zetten waarin wordt onderzocht in hoeverre koeien geleerd kan worden om te urineren op een specifieke plek. Gestart zal worden met 2 koeien. Onderzocht zal worden wat belonend is en hoe het leerprotocol opgezet moet worden. Het urineren zal niet via een farmacologische weg opgewekt worden. Het is de bedoeling dat koeien tijdens de training een verband gaan leggen tussen het urineren in de urineerbox en het ontvangen van een beloning. Dit experiment is beschreven in hoofdstuk 4.

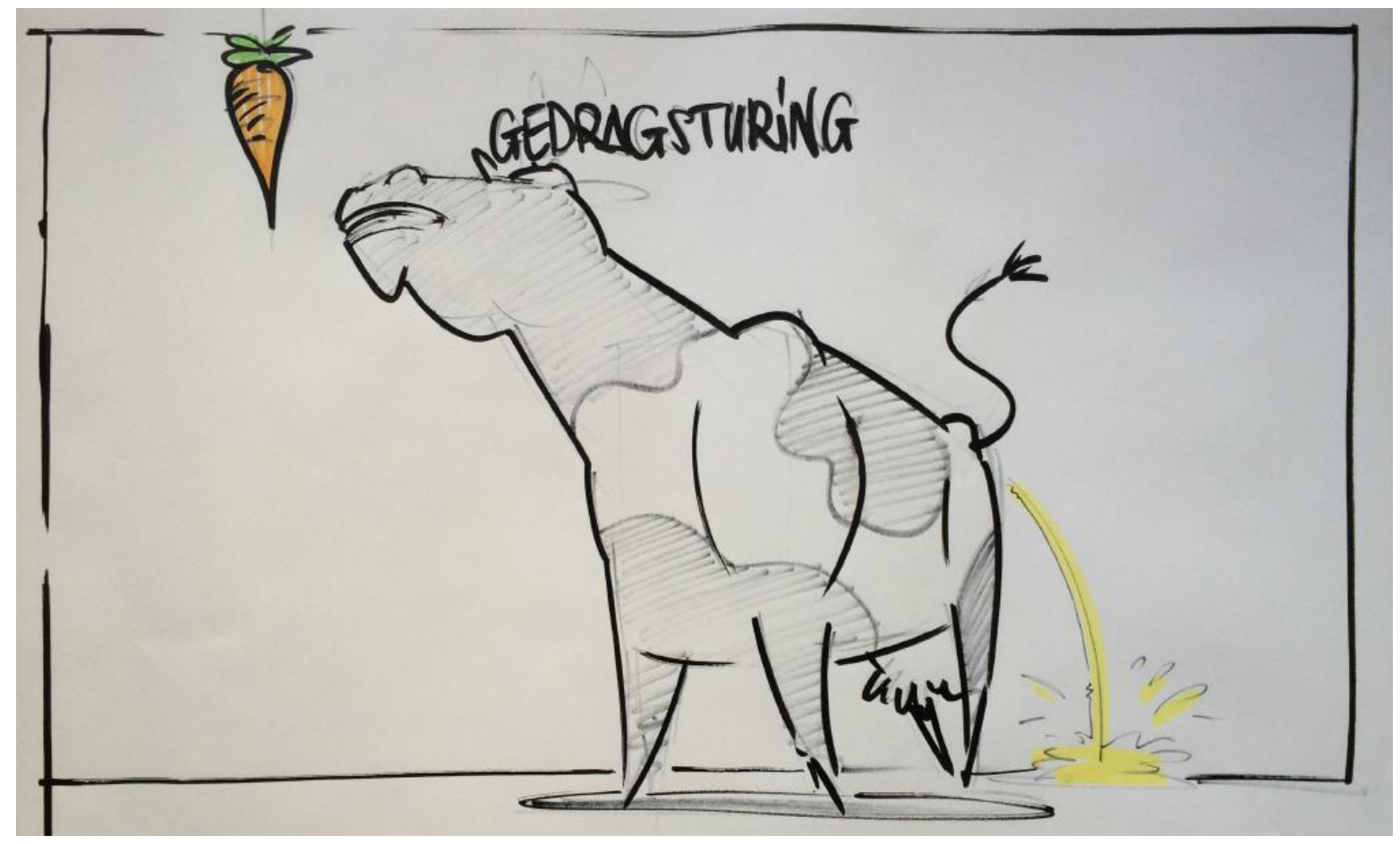




\section{$4 \quad$ Pilot onderzoek trainen van koeien}

Kees van Reenen, Theo van Hattum, Machteld van Dierendonck en Kathalijne Visser

\subsection{Inleiding}

Een mogelijke strategie waarmee scheiding van mest en urine bij melkkoeien bewerkstelligd zou kunnen worden is om koeien te leren om op een bepaalde plaats in de stal te urineren. Bijvoorbeeld in een zogenaamde 'urineerbox' of een "plashok". Er zijn op dit moment twee aanwijzingen in de wetenschappelijke literatuur die de gedachte ondersteunen dat dit wellicht mogelijk is. Onderzoek van Whistance et al. (2009) suggereerde dat het urineren van vaarzen wordt gecontroleerd door het willekeurige zenuwstelsel; dit is een belangrijke basisvoorwaarde voor het leren urineren op een bepaalde plaats. Recent is door Vaughan et al. (2014) voor het eerst een daadwerkelijke poging ondernomen om runderen te leren om te urineren op een bepaalde plaats. Zij onderwierpen kalveren aan een vorm van 'operante conditionering' waarbij het urineren op een specifieke plaats - in de vorm van een testbox ('urination stall') - werd gevolgd door het ontvangen van een beloning. In deze proef werd gebruik gemaakt van de toediening van een geneesmiddel (een zogenaamd diureticum) om het urineren farmacologische op te wekken. In een pilotstudie is onderzocht of training van koeien een haalbare methode zou kunnen zijn om koeien te leren om op een specifieke plaats in de stal te urineren.

\subsection{Aanpak trainingen}

Aanvankelijk is ingezet op zogenaamde 'klassieke conditionering' waarbij dieren uiteindelijk het verband leggen tussen een zogenaamde 'geconditioneerde stimulus' en een 'ongeconditioneerde reactie', door tussenkomst van een zogenaamde 'ongeconditioneerde stimulus'. Bij "operante conditionering" leert het dier door het effect, veroorzaakt door zijn gedrag. Het bekendste voorbeeld van "klassieke conditionering" is de hond van Pavlov, die wordt blootgesteld aan een geluid (bel of zoemer = 'geconditioneerde stimulus'), onmiddellijk gevolgd door het verstrekken van een beetje voer (= 'ongeconditioneerde stimulus'). In reactie op het verstrekken van voer produceert de hond speeksel (= 'ongeconditioneerde reactie'). De hond leert uiteindelijk het geluid te combineren met het verstrekken van voer, zodanig dat in reactie op het geluid de productie van speeksel volgt zonder dat er voer wordt verstrekt. Voorbeelden van klassieke conditionering bij landbouwhuisdieren zijn, bijvoorbeeld, het lekken van melk uit de uier van melkkoeien in reactie op het aanzetten van de melkmachine, voordat koeien daadwerkelijk worden gemolken, of het opgewonden raken van dekhengsten in reactie op het geluid van het halster dat gebruikt wordt tijdens het dekken van merries, voordat de daadwerkelijke dekking plaatsvindt (McGreevy, 2012). Deze auteur noemt in zijn boek over beleren van paarden nog een andere vorm van klassieke conditionering, die ook relevant zou kunnen zijn voor het leren van koeien om op een bepaalde plaats te urineren. Verzorgers van racepaarden fluiten elke keer dat zij hun paard zien urineren. Paarden blijken uiteindelijk de associatie tussen fluiten en urineren te kunnen leggen, en op commando te kunnen urineren - in reactie op fluiten - wanneer nà een race urine nodig is voor onderzoek. De aanname is dat het urineren zelf in zekere zin belonend is, en fungeert als 'ongeconditioneerde reactie'. Naar analogie met het trainen van paarden is zodra een koe spontaan urineert een fluitsignaal ten gehore gebracht - dat wil zeggen - een 'geconditioneerde stimulus'.

Nadere discussie - en consultatie met dr. Paul McGreevy, een expert in leergedrag van dieren - heeft geresulteerd in een alternatieve aanpak gebaseerd op 'operante conditionering' die relevanter werd geacht. De aanpak die de meeste kans succes werd toegedicht bestond uit 'operante conditionering' waarbij gebruik werd gemaakt van een zogenaamde 'primary reinforcer' bestaande uit een voerbeloning en een 'secondary reinforcer' bestaande uit een fluitsignaal (in trainingsprogramma's 
met, bijvoorbeeld, honden wordt vaak gebruik gemaakt van een 'clicker' als secondary reinforcer). Een dergelijke training bestaat uit drie (geleidelijk in elkaar overlopende) fasen:

- Fase 1. Koeien worden geleerd om een secondary reinforcer - zoals een fluitsignaal - te associëren met de primary reinforcer in de vorm van een voerbeloning.

- Fase 2. Vervolgens worden de koe blootgesteld aan het fluitsignaal direct nadat zij heeft geürineerd, waarna de voerbeloning volgt op de plek van urineren, met behulp van een voerbakje. Middels training wordt de koe geleerd om, nadat zij heeft geürineerd en er een fluitsignaal is afgegeven, de voerbeloning steeds verder van de plaats van urineren te consumeren. Een gewenst resultaat in dit stadium bestaat eruit uiteindelijk dat koeien laten zien dat ze de link leggen tussen fluitsignaal, urineren en een voerbeloning, en dat ze het urineren ophouden tot dat ze de specifieke plek hebben bereikt waar het voer wordt verstrekt.

- Fase 3. In het eindstadium van een succesvolle training is het de bedoeling dat een koe zich naar de specifieke plaats, zoals een 'urineerbox', begeeft om daar te urineren, waarna het fluitsignaal klinkt en de voerbeloning wordt verstrekt.

\section{Uitvoering van de training}

\section{Fase 1}

$\mathrm{Er}$ is gewerkt met twee koeien (beiden pariteit 3 en in hetzelfde stadium van de lactatie), in een afgezet gedeelte van de ligboxenstal op het proefbedrijf CARUS in Wageningen (zie figuur 3 ). Om praktische redenen werd in verschillende fasen van de training gebruik gemaakt van verschillende gedeelten van de ligboxenstal. Het leeronderzoek werd uitgevoerd gedurende de werkdag
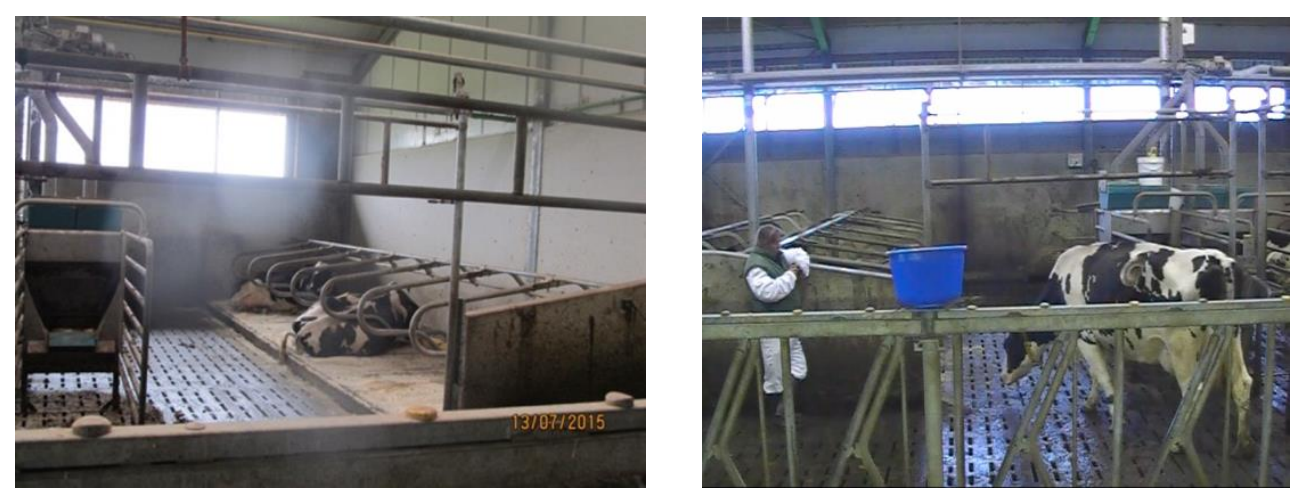

Figuur 3. Ruimte waar de training van koeien werd uitgevoerd.

Linkerfoto: ruimte waar fase 1 werd uitgevoerd.

Rechterfoto: ruimte waar fase 2 van het onderzoek werd uitgevoerd. De persoon is de trainer die zodra een koe urineert het fluitsignaal behorend bij de betreffende koe laat horen. Daarna geeft een tweede persoon (links van de trainer, buiten beeld) onmiddellijk een voerbeloning uit de emmer.

Voor elke koe is een ander fluitsignaal gebruikt, respectievelijk een scheidsrechters fluitje en een hondenfluitje. Gedurende een periode van één week is de koeien geleerd om in reactie op hun specifieke fluitsignaal een voerbeloning in de vorm van een (kleine) portie krachtvoerbrokjes op te komen halen op een vaste plaats in de stal. Daarna is gedurende de daaropvolgende week geleerd om in reactie op het fluitsignaal de voerbeloning op te halen op variabele plaatsen in de stal. Het voer werd verstrekt in een blauwe emmer.

\section{Fase 2}

Op 17 waarnemingsdagen zijn gedurende een waarnemingsperiode van in het totaal 93 uur alle eliminaties (lozingen van urine en van mest; respectievelijk 74 lozingen van urine, en 88 lozingen van mest) bij één proefkoe gepaard met het toepassen van de 'secondary reinforcer' in de vorm van het fluitsignaal in combinatie met het direct verstrekken van de voerbeloning. Gaandeweg deze waarnemingsperiode is de emmer steeds ietsje verder van de koe neergezet. Er is in het bijzonder gelet op signalen die erop zouden kunnen duiden dat de koe op het moment dat zij aandrang voelt om te gaan urineren hetzij naar de emmer met de voerbeloning ('primary reinforcer'), hetzij naar de trainer met het fluitje in de mond ('secondary reinforcer') kijkt. In het ideale geval zou een koe zich op het moment dat zij aandrang voelt al naar de emmer met de voerbeloning toe bewegen. Eventueel zou zij dan 'onderweg' al met urineren of mesten kunnen beginnen. Deze gewenste reacties zijn niet of nauwelijks waargenomen. 


\section{Conclusies van de pilotstudie}

Onder de condities waaronder de pilotstudie is uitgevoerd werd fase 1 van het beoogde conditioneringsproces succesvol afgerond. Fase 2, daarentegen, leidde niet tot gedragingen van de proefkoe die erop kunnen wijzen dat het dier het optreden van lozingen van urine associeerde met het verkrijgen van een voerbeloning. Het feit dat alleen lozingen van urine en mest gedurende de dag werden gecombineerd met het fluitje in combinatie met de voerbeloning betekende dat alle eliminaties gedurende de avond en nacht onbeloond bleven. Dit kan het leerproces tenminste vertraagd en wellicht zelfs tegengewerkt hebben.

\subsection{Herziene trainingsmethode}

Gelet op de resultaten van de pilotstudie zijn een aantal aanbevelingen geformuleerd voor mogelijk vervolgonderzoek:

- $\quad$ Als secondary reinforcer zou ook een triller gebruikt kunnen worden die aan de halsband wordt bevestigd. Voordeel van een triller is dat meerdere dieren tegelijk getraind kunnen worden. Een dergelijke triller is gebruikt bij virtual fencing.

- Voor de eerste fase van de training waarbij de secondary reinforcer wordt geassocieerd met een voerbeloning is het noodzakelijk dat kleine porties krachtvoer aan koeien kunnen worden verstrekt exact op het moment dat wij dat willen. Dit vereist een andere instelling van de krachtvoerautomaat en een manier om op het moment dat wij dat willen een klein portie krachtvoer aan een koe te vertrekken.

- $\quad$ Tijdens deze fase van de training is het handig als koeien onderscheid kunnen maken tussen periodes waarin er in de krachtvoerbox wordt getraind en periodes waarin dat niet geval is. Hiervoor zou bijvoorbeeld een lamp gebruikt kunnen worden: licht aan is "training" en licht uit is "geen training".

- Uit de waarnemingen blijkt dat de koeien niet bijzonder frequent urineren. Het zou kunnen zijn dat spontane urinelozingen niet vaak genoeg voorkomen om een zinvolle training uit te kunnen voeren. Dit zou er voor kunnen pleiten om, naar analogie van de studie van Vaughan et al. (2014), gebruik te maken van een methode om lozingen van urine te induceren. Dat kan farmacologisch, maar dat zou wellicht ook op een mechanische wijze kunnen worden bewerkstelligd (zie hoofdstuk 5 van dit rapport).

- Een alternatieve trainingsmethode, waarbij rekening wordt gehouden met de hierboven genoemde aanbevelingen, zou eruit kunnen bestaan dat koeien eerst leren dat zij een voerbeloning kunnen verkrijgen in een aangepaste krachtvoerbox in de vorm van een zogenaamde 'urineerbox' (zie hoofdstuk 6 van dit rapport). De voerbeloning ('primary reinforcer') gaat automatisch gepaard met trilsignaal via een triller aan de halsband ('secondary reinforcer'). In een volgende fase worden urinelozingen (bijvoorbeeld mechanisch) gestimuleerd zodra een koe in de urineerbox staat. Het daadwerkelijk optreden van een urinelozing wordt via een staartsensor automatisch opgemerkt (zie hoofdstuk 4 van dit rapport) en dat leidt automatisch tot het trilsignaal en de voerbeloning. Het trilsignaal is dus bedoeld om de training effectiever te maken. Een aldus geautomatiseerd trainingsprotocol zou in principe 24 uur per dag, 7 dagen per week, kunnen worden toegepast; daarmee zou wellicht uiteindelijke wèl voldaan kunnen worden aan de benodigde frequentie van 'beloonde' urinelozingen om een tot een succesvol leerproces te leiden waarbij koeien uiteindelijk actief de urineerbox opzoeken om pas een voerbeloning te krijgen nadat ze hebben geürineerd. Het urineren in de urineerbox (in combinatie met het zich bewegen naar de urineerbox op het moment dat er sprake is van aandrang) is dan feitelijk de 'operante reactie' die koeien laten zien voorafgaan aan de voerbeloning. 


\section{$5 \quad$ Detectie van eliminaties (lozing van mest en urine) van melkvee}

Wijbrand Ouweltjes en Joop van der Werf

\section{$5.1 \quad$ Inleiding}

Het literatuuronderzoek uit hoofdstuk 2 liet zien dat mesten en urineren bij melkkoeien in het algemeen gepaard gaan met kenmerkende veranderingen van de lichaamshouding. Wanneer een staande koe gaat mesten wordt het lichaam licht naar achteren gekanteld, de staart gaat omhoog, en de rug wordt licht gebogen. Bij urineren wordt de rug nog iets sterker gebogen en bovendien worden de achterpoten iets naar voren en uit elkaar gezet (Aland et al., 2002), maar de verschillen in houding zijn tamelijk subtiel. Deze gedragskenmerken worden in het algemeen gebruikt als visuele indicatoren voor het detecteren van mest- en urinelozingen (Whistance et al., 2007). Bij live observaties van dieren is in principe eenvoudig waar te nemen wanneer mest of urine worden geloosd, maar ook wanneer gebruik gemaakt wordt van beeldopnames is dit zeer arbeidsintensief. Er zijn momenteel geen goede gevalideerde sensoren of andere hulpmiddelen om tijd en plaats van individuele lozingen geautomatiseerd te registreren onder praktijkomstandigheden.

Doordat het verzamelen van gegevens over mest- en urinelozingen (tijdstip, welk dier en op welke plaats) zeer arbeidsintensief is zijn er alleen betrekkelijk kleine datasets verzameld, en is er weinig inzicht in bijvoorbeeld de individuele variatie, voorspelbaarheid en invloed van managementfactoren. Om goed te kunnen onderzoeken of lozingen van mest en urine naar plaats en vooral tijd voorspeld kunnen worden en welke factoren van invloed zijn op uitscheidingsgedrag, zijn veel en betrouwbare data nodig van lozingen in combinatie met gegevens van potentiele voorspellende kenmerken. Voor het onderzoeken van mogelijke voorspellers of optimalisaties is het voldoende om retrospectief over deze gegevens te kunnen beschikken, maar voor andere doeleinden die ook in dit rapport worden besproken is het wenselijk om ze ook real time beschikbaar te hebben:

- $\quad$ Stimuleren van urinelozingen werkt waarschijnlijk veel beter bij dieren met een aanzienlijke blaasvulling dan bij dieren die een vrijwel lege blaas hebben. De verwachting is dat de tijd die is verstreken sinds de laatste urinelozing sterk bepalend is voor de vulling van de blaas maar ook voor de grootte van de lozing (zowel van mest als urine).

- Eén van de gedachten om scheiding van mest en urine te kunnen bewerkstelligen is dieren de lozingen (met name van urine) te laten doen op speciale plaatsen, zogenaamde urineerboxen. Het is echter nog niet duidelijk in welke mate dit mogelijk is. Door training, waarbij koeien een beloning (lekker krachtvoer) ontvangen als ze inderdaad op de gewenste plek lozen, kan een associatie worden opgebouwd tussen gewenst gedrag en beloning. Als lozingen niet geautomatiseerd kunnen worden opgespoord is praktisch vrijwel niet te voorkomen dat de dieren bij een aanzienlijk deel van hun lozingen in de trainingsperiode niet beloond zullen worden, ongeacht het gedrag wat ze daarbij vertonen. Dit komt waarschijnlijk het leerproces niet ten goede, en zou ook een belemmering kunnen zijn bij gebruik van een urineerbox onder praktijkomstandigheden.

De hypothese van dit deelonderzoek was dat bewegingen van de staart in combinatie met beeldmateriaal bruikbaar zijn om lozingen van zowel mest als urine nauwkeurig te detecteren, en dat staartbewegingen met behulp van bewegingssensoren gemonitord kunnen worden. Het doel van dit onderzoek was het ontwikkelen van een methode om op een relatief eenvoudige maar betrouwbare wijze gebeurtenissen "lozing van mest en urine" nauwkeurig zowel qua individu, plaats als tijd te registreren. Daarnaast leverde dit onderzoek een dataset op met dergelijke gegevens en aanvullende sensor-informatie, maar de omvang van deze dataset was niet toereikend om voorspelbaarheid van lozingen te onderzoeken. Voor dit onderzoek zijn naast enkele pilot-onderzoeken met beeldopnames en staartsensoren een tweetal experimenten uitgevoerd op Dairy Campus. In dit hoofdstuk worden de resultaten en de verkregen inzichten beschreven. 


\subsection{Ontwikkeling detectiemethode}

Door middel van een aantal pilot-onderzoeken (Ouweltjes en Van der Werf, 2016) is een methode ontwikkeld om gegevens van staartbewegingen met versnellingsopnemers te monitoren. Deze sensoren worden in het vervolg aangeduid met "staartsensoren", maar dat heeft vooral betrekking op de plek waar ze aan de koeien zijn bevestigd. De behuizing en wijze van bevestiging van de sensoren aan de staart is daarbij een belangrijk aandachtspunt, enkele stappen zoals toegepast bij het laatst uitgevoerde experiment (april 2016) staan in figuur 4.
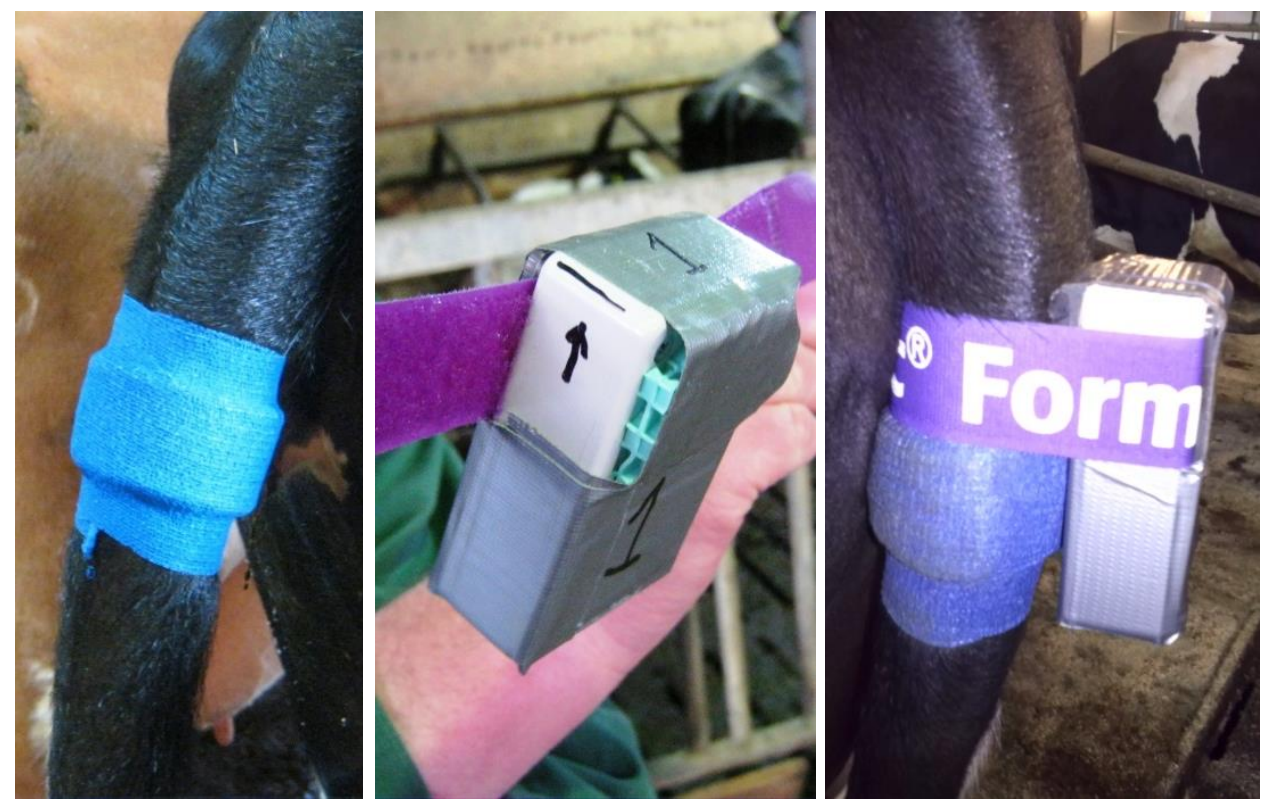

Figuur 4. Het aanbrengen van de staartsensor.

Links: een band om de staart om de sensor niet te kunnen verliezen.

Midden: de staartsensor.

Rechts: de staartsensor is bevestigd.

In twee experimenten op Dairy Campus (juli 2015 en april 2016) is een groep koeien uitgerust met een staartsensor en o.a. een IceQube activiteit sensor en zijn video-opnames gemaakt van de leefruimte van deze dieren met een viertal camera's. Vastgesteld is dat de koeien bij goede bevestiging gedurende een periode tot ruim 7 dagen geen meetbaar ongerief ondervonden van de staartsensoren. Er zijn rekenregels ontwikkeld waarmee uit de gegevens van de staartsensoren attenties worden gegenereerd die aangeven wanneer een koe de staart optilt ("staartattenties"). Het beeldmateriaal van het eerste experiment is bovendien integraal beoordeeld op lozingen van mest en urine ("beeldattenties").

Uit koppeling van de beeldattenties met de staartattenties van dezelfde dieren is geconcludeerd dat bij door waarnemers visueel geconstateerde lozingen van dieren met een goed functionerende staartsensor vrijwel altijd ( $>87 \%$ ) een staartattentie was berekend, maar ook dat in een aantal gevallen staartattenties gebruikt konden worden om door de waarnemers gemiste lozingen op te sporen en behulpzaam waren bij het juist identificeren van de lozende dieren. Doordat de bevestiging van de staartsensoren in dit experiment (juli 2015) nog niet optimaal was waren er bij enkele koeien veel staartattenties die niet aan een lozing gekoppeld konden worden, maar desondanks was er bij ruim $75 \%$ van de staartattenties een daadwerkelijke lozing van mest of urine. Het beeldmateriaal van lozingen waarbij geen staartattentie was berekend is eveneens visueel gecontroleerd, en daaruit bleek dat bij het merendeel van deze lozingen de staart wel degelijk werd opgetild. Het overgrote deel hiervan was afkomstig van één dier dat erg dun op de mest was en de staart relatief weinig optilde maar waarbij de sensor ook wat scheef aan de staart was bevestigd. Ook mestlozingen van liggende dieren werden soms door de sensors gemist, hoewel deze dieren in het algemeen de staart wel bewogen. Uit deze bevindingen is geconcludeerd dat staartbewegingen goed bruikbaar zijn voor het opsporen van lozingen van mest en urine, maar dat de berekening van staartattenties waarschijnlijk nog verder geoptimaliseerd kan worden. Vooral van belang is dat de staartsensoren goed en gestandaardiseerd aan de staart worden bevestigd. Het merendeel van de gegevens over lozingen is in dit experiment verzameld door uitlezing van beeldmateriaal en nog in beperkte mate op gegevens van de staartsensoren, mede omdat slechts bij enkele dieren deze gedurende het hele experiment goed aan de staart waren blijven zitten. 
Voor het tweede experiment (april 2016) is de bevestiging van de staartsensoren aangepast en verder gestandaardiseerd. Bovendien is de roterende veeborstel tijdelijk uitgeschakeld om te voorkomen dat de koeien door intensief gebruik hiervan de staartsensor zouden kunnen verliezen. Wederom zijn uit de gegevens van de staartsensoren staartattenties berekend, hierbij is gebruik gemaakt van dezelfde rekenregel als in het eerste experiment. Voor dit experiment is het beeldmateriaal niet integraal beoordeeld, maar is met behulp van zelfgeschreven Matlab-programmatuur per staartattentie een kort filmpje gemaakt waarin de beelden van de 4 camera's waren geïntegreerd. Ieder filmpje startte op het moment dat de staart volgens de sensor omhoog werd gebracht en eindigde zodra de staart weer in de normale stand was gekomen. Vervolgens is met behulp van een tweede in Matlab geschreven programma voor alle staartattenties dit beeldmateriaal beoordeeld en is gescoord of en zo ja wat (mest of urine) er geloosd werd en waar in de stal dat precies gebeurde. Daarbij werd naast bewegend beeld ook gebruik gemaakt van stilstaande beelden (Iosse frames uit de video-opnames). Voor opsporen en herkennen van de individuele koeien zijn foto's van de beide zijkanten per koe gebruikt. Een voorbeeld van de scherm-lay-out is weergegeven in figuur 5.

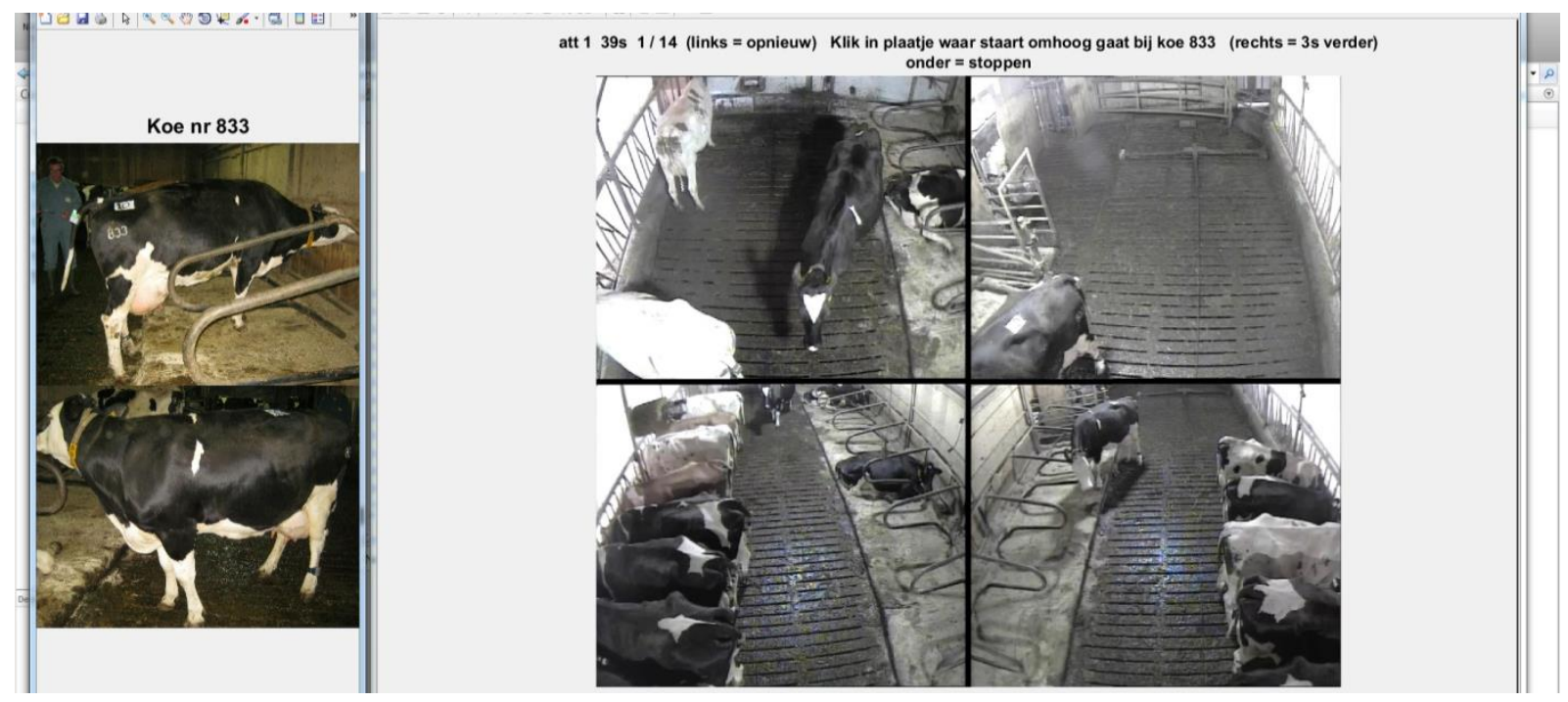

Figuur 5. Voorbeeld scherm lay-out bij opzoeken dier met staartattentie.

Het doel van dit experiment was om een werkwijze te ontwikkelen om informatie van de staartsensoren te combineren met informatie uit beeldmateriaal en zo op een nauwkeurige maar efficiënte manier betrouwbare gegevens over lozingen van mest en urine te verkrijgen. Door de verbeterde bevestiging konden nu van 11 dieren gegevens van de staartsensoren worden verzameld en zijn de sensoren in het algemeen goed op hun plek blijven zitten. Er zijn 1662 staartattenties berekend waarvoor het bijbehorende beeldmateriaal kon worden gecontroleerd. In alle gevallen bleek de koe de staart daadwerkelijk op te tillen, in $82 \%$ van de gevallen werd er ook mest of urine geloosd. $\mathrm{Bij} 6 \%$ van de attenties was niet na te gaan of er werd geloosd, ofwel omdat de koe buiten beeld was (in de melkstal) of omdat het beeld geen uitsluitsel gaf, bij de overige $12 \%$ van de attenties werd wel de staart opgetild (bijvoorbeeld tijdens zelfverzorging) maar werd niet geloosd. Alle gegevens over lozingen in dit experiment zijn verzameld uit een gerichte combinatie van beeldmateriaal en gegevens van staartsensoren. Met deze methode kan een aanzienlijke tijdsbesparing worden gerealiseerd bij het verzamelen van gegevens over lozingen in vergelijking met directe visuele observatie, omdat slechts een fractie van al het vastgelegde beeld hoeft te worden beoordeeld. Voor controle van staartattenties van 11 dieren uit een groep van 15 hoefde in dit onderzoek slechts $12 \%$ van het beeldmateriaal te worden bekeken. Omdat daarbij bovendien de beelden van de 4 gebruikte camera's werden samengevoegd hoefde feitelijk maar 3\% van de totale opnameduur te worden afgekeken. Het beeldmateriaal kon op basis van attenties bovendien veel gerichter worden gecontroleerd dan bij integrale beoordeling zonder attenties, omdat dan op alle dieren gelet moet worden. Een voordeel van gebruik van beeldmateriaal boven directe visuele observatie is dat waarnemingen kunnen worden geverifieerd. Door de combinatie van staartattenties met videobeelden is daarom niet alleen een grote tijdwinst te boeken, maar is de kwaliteit van de verzamelde data waarschijnlijk ook beter. 


\subsection{Verzamelde gegevens over lozingen}

In het eerste experiment zijn in totaal 488 lozingen van mest en 285 lozingen van urine gedetecteerd binnen een periode van 51 uur in het beoordeelde beeldmateriaal van 15 verschillende dieren. In geen enkel geval werden mest en urine gelijktijdig geloosd. Bij 14 van de mest-lozingen lag de koe, in alle overige gevallen stond of liep het dier. Liggend urineren is in dit experiment niet waargenomen. De koeien hebben gemiddeld 15.2 keer gemest en 8.9 keer geürineerd per etmaal. De variatie tussen individuele dieren was groot: voor mesten van 9.4 tot 28.1 keer en voor urineren van 6.1 tot 13.6 keer per etmaal gemiddeld. Zowel mesten als urineren kwamen in iedere uurperiode van het etmaal voor. Op het eerste gezicht was er geen duidelijk verband tussen de frequentie waarmee mest en urine door individuele dieren werden geloosd.

In het tweede experiment zijn met behulp van de 1662 staartattenties 840 mestlozingen en 526 urinelozingen gedetecteerd voor 11 dieren in een periode van ruim 137 uur. Vergeleken met de gegevens van het eerste experiment waren er minder niet aan lozingen gekoppelde attenties, waarschijnlijk hebben zowel de verbeterde bevestigingsmethode, de kleinere behuizing van de staartsensor als het direct uitschakelen van de veeborstel daar aan bijgedragen. Het optillen duurde gemiddeld langer bij urineren (ruim 43 seconden) dan bij mesten (ruim 33 seconden). Er was een aanzienlijke variatie in de duur van het optillen van de staart: voor mesten van 11 tot 100 seconden en voor urineren van 12 tot 151 seconden. Zodra de staart werd opgetild kwam de lozing in de meeste gevallen vrijwel onmiddellijk op gang. Het aantal mestlozingen per koe per etmaal varieerde van 10.6 - 21.1 (gemiddeld 14.7) en het aantal urinelozingen van 5.1 - 17.2 (gemiddeld 9.4). Indien deze variatie tussen dieren in de tijd consistent is dan dient hiermee rekening te worden gehouden bij voorspelling van lozingen. Uit de gegevens blijkt vooralsnog geen duidelijk verband tussen het aantal mest- en urinelozingen per koe (Figuur 6).

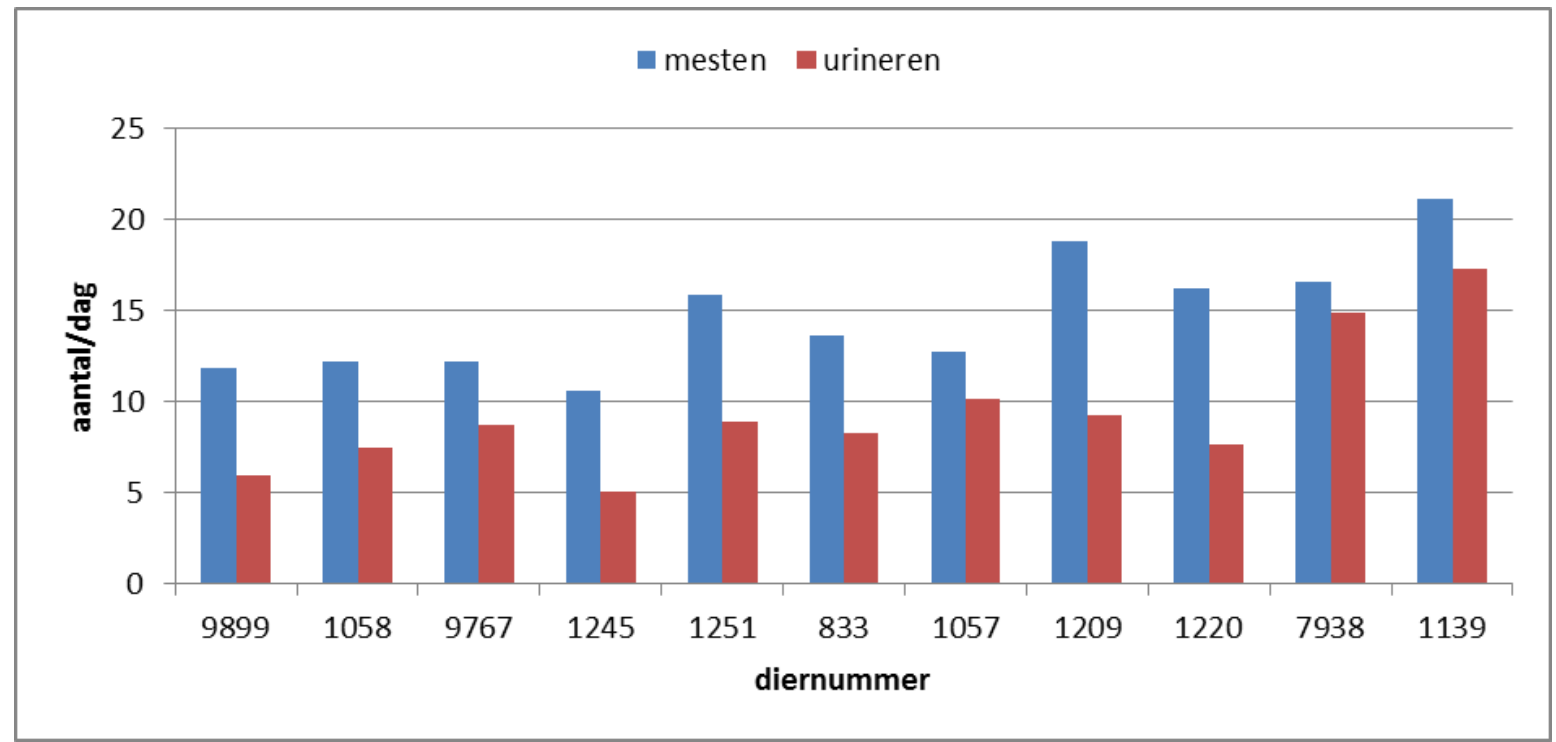

Figur 6. Gemiddeld aantal lozingen per koe per etmaal van mest en urine.

Voor verwijdering van mest kan ook van belang zijn hoe de verdeling van lozingen op koppelniveau in de tijd verloopt. Daarom is de verdeling van de aantallen lozingen van deze groep van 11 dieren per uurperiode geteld voor een periode van exact 5 etmalen (van 8 april 17:51 uur tot 13 april 17:51 uur) en in percentages weergegeven in Figuur 7. 


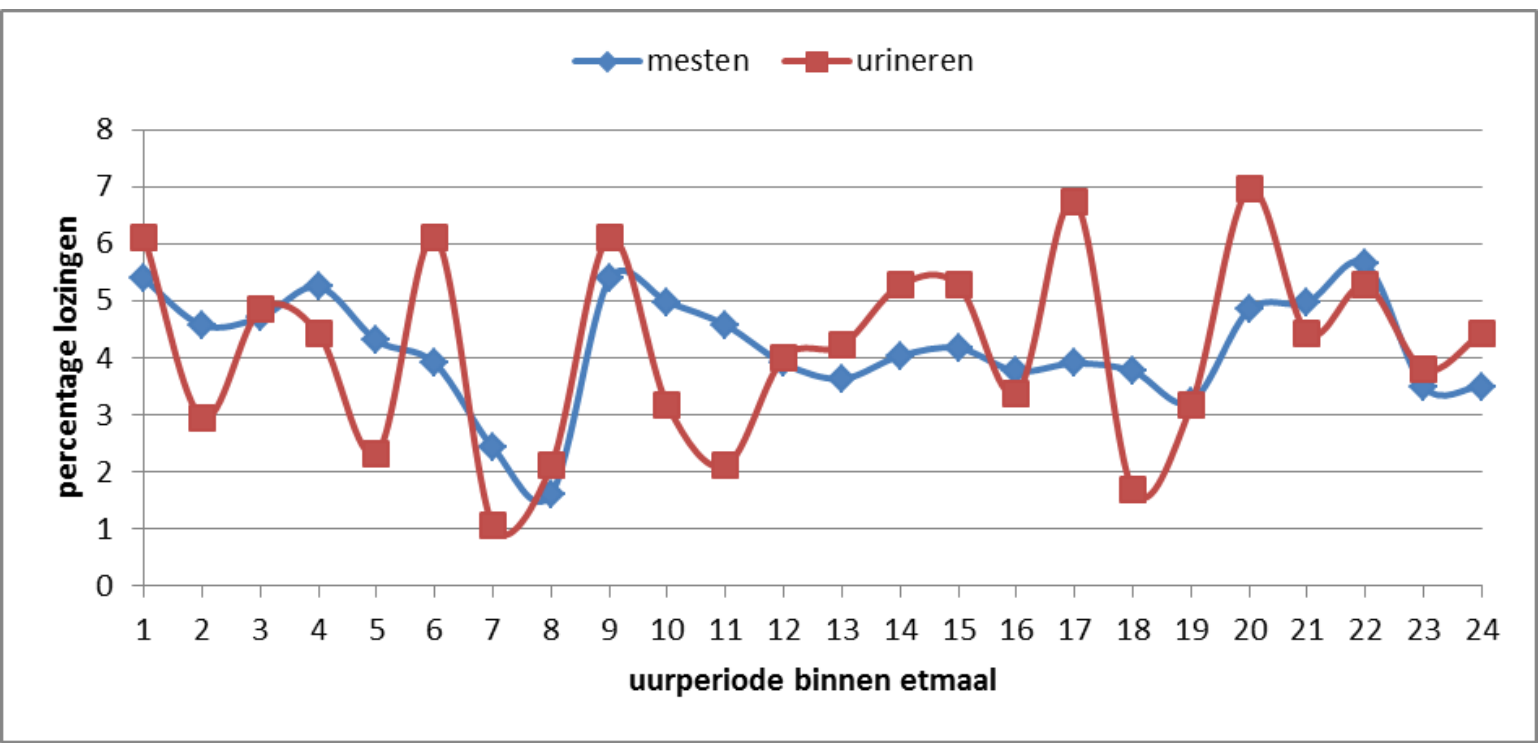

Figuur 7. Verdeling aantal lozingen mest en urine over etmaal voor groep van 11 koeien DC april 2016.

Voor deze groep koeien blijkt met name het aantal mestlozingen wat lager te zijn geweest dan gemiddeld in de periode tussen 5 en 7 uur 's ochtends, mogelijk dat dit samenhangt met melken en voeren. $\mathrm{Er}$ is echter geen nachtelijke periode waarin er een duidelijk geringer aantal lozingen is geweest. In het merendeel van de gevallen was de volgende lozing van dezelfde koe na mesten een urinelozing (451 keer, gemiddeld 2801 seconden later maar met een range van 48 tot 15785 seconden), maar het kwam ook regelmatig voor dat de volgende lozing na mesten wederom mest betrof (381 keer, gemiddeld 4778 seconden later maar met een range van 39 tot 14519 seconden). $\mathrm{Na}$ een urinelozing volgde meestal een mestlozing (452 keer, gemiddeld 3076 seconden later met een range van 22 tot 16151 seconden), urineren als eerstvolgende lozing kwam 71 keer voor (met een gemiddeld interval van $6714 \mathrm{sec}$ en range van 285 tot 14656 seconden). Wederom vonden alle urinelozingen en vrijwel alle mestlozingen plaats terwijl het betreffende dier stond (of liep). Mogelijk zijn er wel enkele mestlozingen tijdens ligbouts gemist doordat de berekening van staartattenties nog niet is aangepast voor liggende dieren, dit zou nog nader kunnen worden onderzocht.

Om inzicht te krijgen in de ruimtelijke verdeling van de lozingen is de plattegrond van de stal in vakken van $50 * 50 \mathrm{~cm}$ opgedeeld. Per vak is het aantal mest- en urinelozingen geteld wat daar heeft plaatsgevonden, de verdeling is weergegeven in Figuur 8. Des te donkerder het vak is gekleurd des te meer lozingen er zijn geweest.

overzicht lozingen mest

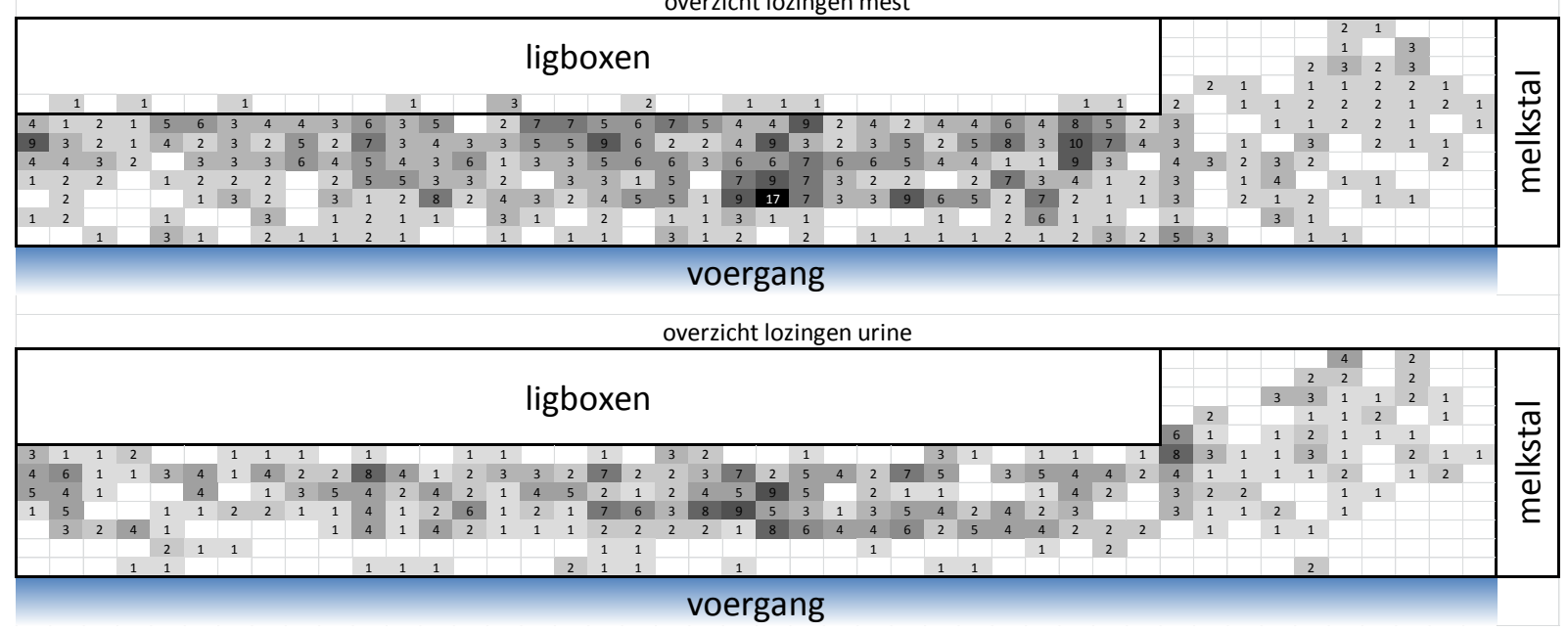

Figuur 8. Ruimtelijke verdeling lozingen mest en urine.

Het merendeel van de lozingen heeft plaats gevonden op de roostervloer achter de ligboxen, met relatief weinig lozingen vlak achter het voerhek. Opvallend is dat het aantal urinelozingen pal achter de ligboxen kleiner was dan meer naar het midden van de loopvloer. Verder waren er relatief veel urinelozingen bij de krachtvoerbox (pal naast de ligboxen). 


\subsection{Verkenning voorspelbaarheid lozingen}

Een van de denkrichtingen van het onderzoek naar primaire mestscheiding is het gescheiden opvangen van mest- en urinefracties. Daarbij is het heel behulpzaam indien lozingen in de tijd vooraf voorspeld kunnen worden. Omhoog bewegen van de staart komt hiervoor niet in aanmerking, omdat de lozing daar in de meeste gevallen vrijwel direct op volgt zodat er vrijwel geen mogelijkheden zijn om vervolgens opvang van de lozing te bewerkstelligen.

Hoewel, zoals eerder aangegeven, de binnen dit onderzoek verzamelde hoeveelheid gegevens over lozingen niet toereikend is om de voorspelbaarheid goed te kunnen onderzoeken zijn wel mogelijke verbanden geïnventariseerd tussen lozingen en de overige verzamelde sensorgegevens. Dit betreft met IceQubes verzamelde gegevens over ligbouts en met RumiWatches verzamelde gegevens over herkauwen, vreten en drinken. De sensor-gegevens zijn per koe in de tijd gekoppeld aan de waargenomen mest- en urinelozingen en in grafieken weergegeven om zo een indruk te krijgen van de mogelijke samenhang tussen lozingen en de overige gedragingen. Een voorbeeld van een grafiek met gekoppelde staat in Figuur 9.

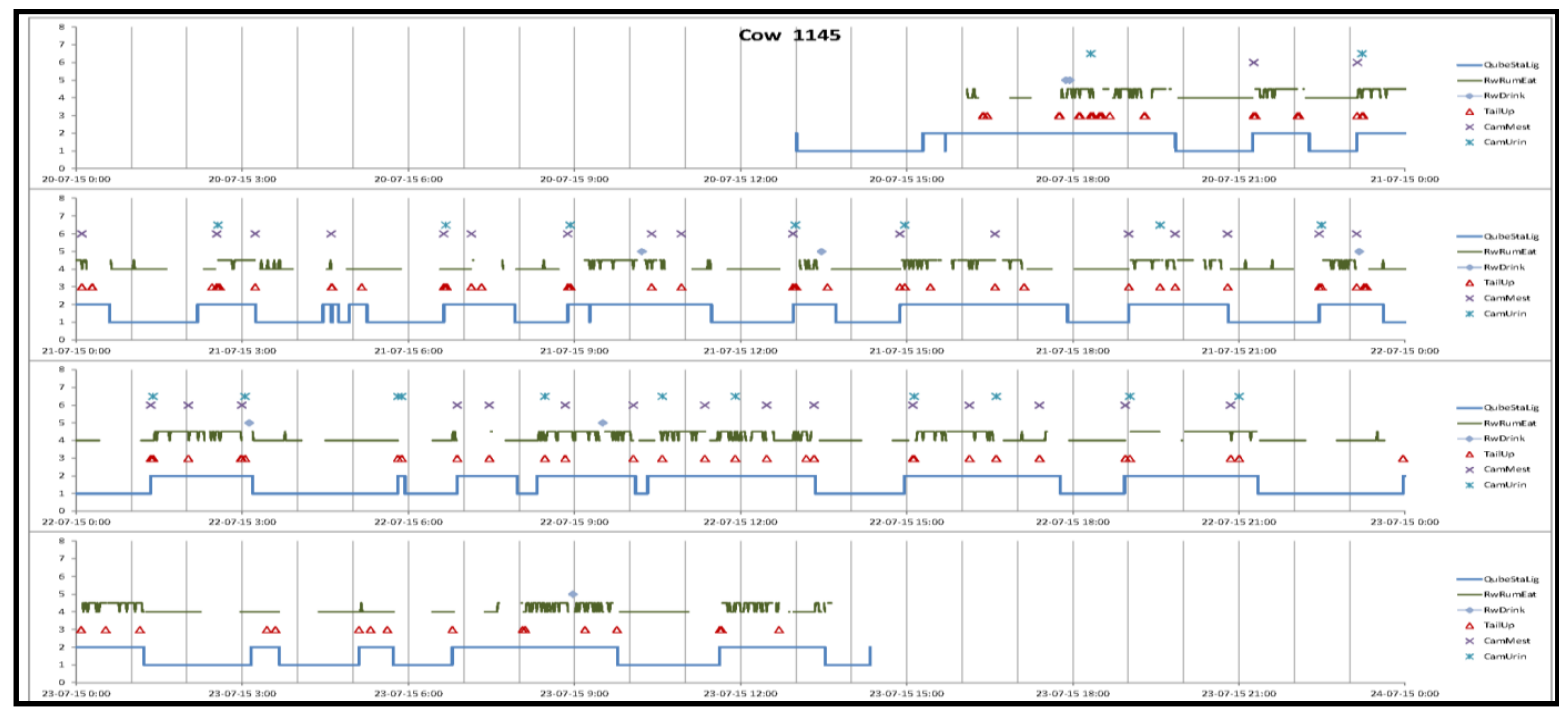

Figur 9. Voorbeeld gekoppelde sensorgegevens koe 1145.

Met de IceQubes zijn de begin- en eindtijden van ligbouts tot op de seconde nauwkeurig vastgelegd, de tussenliggende periodes waarin een koe heeft gestaan of gelopen zijn aangemerkt als stabouts ("QubeStaLig" in heeft dan in Figuur 7 een waarde 2). Met de RumiWatches is per minuut het gedrag gekwalificeerd: herkauwen, vreten, drinken of "anders". In Figuur 7 staat RwRumEat=4 voor herkauwen, RwRumEat $=4.5$ voor vreten en RwDrink $=5$ voor drinken. Verder zijn de staartattenties en de bij het uitlezen van de beelden vastgelegde beeldattenties voor mesten en urineren in Figuur 7 weergegeven. Vaak is er net na opstaan een mestlozing en vaak ook een urinelozing, maar de meeste lozingen vinden plaats op andere momenten tijdens de stabouts. Vlak voor gaan liggen is er soms een lozing, maar dat lijkt minder vaak voor te komen. Er zijn geen aanwijzingen gevonden voor een relatie met vreten, herkauwen of drinken.

\subsection{Samenvatting en conclusies}

Het inzicht in het gedrag van melkkoeien wat betreft het spontaan lozen van mest en urine naar plaats en tijd ("hoe", "waar" en "wanneer") is beperkt. Uit dit onderzoek blijkt dat lozende koeien meestal staan of lopen, maar soms mesten dieren terwijl ze liggen. Bepaalde dieren lijken dit relatief vaak te doen. Lozingen gaan vrijwel altijd gepaard met omhoog bewegen van de staart, al kan dat bij koeien die erg dun op de mest zijn op tamelijk subtiele wijze gebeuren. Daardoor is de kans aanzienlijk dat dergelijke lozingen ook bij visuele controle van beeldmateriaal of directe observatie worden gemist.

\subsubsection{Ontwikkelde methode voor verzamelen gegevens over mesten en urineren}

Binnen dit onderzoek is een werkwijze ontwikkeld die het mogelijk maakt om een sensor zodanig aan de staart te bevestigen dat deze goed blijft zitten zonder dat de koe daar merkbare overlast van 
ondervindt. Omhoog bewegen van de staart kan met aan de staart bevestigde sensoren en betrekkelijk eenvoudige rekenregels worden gedetecteerd. De staartattenties geven weliswaar een sterke aanwijzing dat een koe mest of urine loost, maar uit de staartbeweging alleen kan niet op betrouwbare manier onderscheid worden gemaakt tussen mesten, urineren en overige staartbewegingen. Voor verder geautomatiseerde detectie van mest- en urinelozingen is aanvullende informatie nodig naast de staartbewegingen. Staartattenties in combinatie met beeldmateriaal kunnen worden gebruikt om op een efficiënte en betrouwbare manier gegevens over lozingen (exacte plaats en tijdstip, soort lozing) van individuele dieren te verzamelen.

\subsubsection{Gedrag, verzamelde gegevens en voorspelbaarheid van lozingen}

Dit onderzoek heeft twee datasets opgeleverd met gegevens over lozingen. De eerste dataset (van de sessie in juli 2015) omvat 488 mestlozingen en 285 urinelozingen van een groep van 15 koeien in ruim 2 etmalen. Deze koeien mestten gemiddeld 15.2 keer per etmaal en urineerden 8.9 keer, maar de variatie tussen dieren was groot. De tweede dataset (van de sessie in april 2016) omvat 840 mestlozingen en 526 urinelozingen van een groep van 11 koeien in ruim 5 etmalen. Deze koeien mestten gemiddeld 14.7 keer per etmaal en urineerden 9.4 keer, wederom was de variatie tussen dieren groot. De bevindingen van beide sessies wat betreft frequentie van lozingen van mest en urine zijn goed in lijn met hetgeen daarover in de literatuur is vermeld (Dixhoorn et al., 2015) en komen ook goed met elkaar overeen. Ook is in overeenstemming met de literatuur geconstateerd dat liggende koeien niet urineren maar incidenteel wel kunnen mesten. Bij de beoordeling van het beeldmateriaal is niet systematisch vastgelegd of de dieren stilstonden of liepen tijdens een lozing, maar is wel waargenomen dat koeien soms lopend mesten. Bij urineren is dat niet geconstateerd, maar dit aspect van het gedrag bij lozingen zou nog nader beoordeeld kunnen worden. Het is denkbaar dat de stalinrichting of managementmaatregelen invloed hebben op de mate waarin koeien lopend mesten. Vergelijking van gedragingen met betrekking tot lozen van mest en urine van weidende dieren en opgestalde dieren kan inzicht opleveren in de mate waarin dit gedrag bij opstallen wordt verstoord.

De periode dat de staart wordt opgetild duurde gemiddeld ruim 40 seconden bij urinelozingen en ruim 30 seconden bij mestlozingen, maar ook aanzienlijk kortere "bouts" kwamen voor. Binnen dit tijdsbestek vindt de lozing plaats. Zowel bij mesten als bij urineren komt het voor dat de lozing met haperingen verloopt, soms wordt zelfs de staart weer omlaag gebracht terwijl de lozing eigenlijk niet echt beëindigd lijkt te zijn. De intervallen tussen opeenvolgende mest- en urinelozingen van individuele dieren varieerden dan ook enorm: van 39 tot 27926 seconden ( 7 uur en 45 minuten) voor mesten (het gemiddelde interval tussen mestlozingen was 5948 seconden ofwel 1 uur en 39 minuten) en van 285 tot 35923 seconden ( 9 uur en 59 minuten) voor urineren (het gemiddelde interval tussen urinelozingen was 9523 seconden ofwel 2 uur en 39 minuten). Vooral bij de zeer korte intervallen zullen het rectum en de blaas na de voorlaatste lozing niet volledig zijn geleegd. Een mogelijke oorzaak hiervoor is dat het dier verstoord werd, maar dit is niet gekwantificeerd. Gezien de enorme variatie in intervallen is het te verwachten dat er ook variatie is in de hoeveelheid mest en urine die per lozing worden uitgescheiden. Voor urinelozingen is dergelijke variatie inderdaad waargenomen door Misselbrook et al. (2016).

Vooral gegevens over liggen en staan lijken in combinatie met staartattenties bruikbaar als mogelijke voorspellers van lozingen. Het onderzoek heeft geen aanwijzingen opgeleverd voor verbanden met voeropname, wateropname en melken. Wel is inzicht verkregen in de ruimtelijke verdeling van lozingen, met de ontwikkelde methode kan de plaats waar geloosd wordt eenvoudig nauwkeurig worden vastgelegd indien de beeld-coördinaten in pixels kunnen worden omgerekend in coördinaten in de stal. Het merendeel van de lozingen heeft plaats gevonden op de roostervloer achter de ligboxen, met relatief weinig lozingen vlak achter het voerhek. In hoeverre dit specifiek is voor de stal waarin het onderzoek is uitgevoerd is niet duidelijk.

\subsubsection{Betekenis van de bevindingen}

Om in praktijksituaties primaire scheiding van mest en urine bij de bron te bewerkstelligen zonder in te grijpen in het natuurlijke gedrag is meer kennis hierover gewenst. Dergelijke kennis zou ook kunnen worden gebruikt om de inrichting van stallen zodanig aan te passen dat emissies worden beperkt. De ontwikkelde methode om gegevens over mest- en urinelozingen te verzamelen kan hierbij zeer behulpzaam zijn, omdat met uitgebreidere datasets meer inzicht verkregen kan worden in factoren die van invloed zijn op de lozing van mest en urine en in de voorspelbaarheid van dergelijke gebeurtenissen naar tijd, plaats en omstandigheden. Op termijn zouden dergelijke inzichten gebruikt 
kunnen worden bij gebruik van een urineerbox. Kennis over waar en wanneer waarschijnlijk een lozing heeft plaatsgevonden of nog bezig is kan mogelijk ook op andere manieren worden toegepast. Des te korter op de eigenlijke lozing deze informatie beschikbaar komt des te meer perspectief dit biedt om emissies te beperken en de hygiëne in de stal te bewaken. Er kan bijvoorbeeld direct actie worden ondernomen om te voorkomen dat koeien over het besmeurde deel van de vloer lopen en de lozing kan indien het mest betreft gericht worden opgeruimd. Wellicht kan dit bijdragen aan beperking van de vorming en emissie van ammoniak. Een dergelijk gebruik van staartsensoren vergt echter wel directe communicatie met overige stalautomatisering, waarschijnlijk moet hiervoor de levensduur van de batterij sterk toenemen en moet de bevestiging van de sensoren aan de staart verder worden geoptimaliseerd. Indien lozingsgedrag wordt gemonitord wordt het ook mogelijk om eventuele afwijkingen hierin op te sporen. Frequent liggend mesten kan bijvoorbeeld een aanwijzing zijn voor pootproblemen of voor verminderd ligcomfort en een verhoogde mestfrequentie voor problemen met de stofwisseling. Naast informatie over lozingen kunnen de gegevens van staartsensoren ook andere informatie opleveren. Zo bleek uit dit onderzoek dat uit de sensor-gegevens eenvoudig is af te leiden op welke zijde een koe ligt. Een verhoogde activiteit van de staart kan duiden op overlast van vliegen (wanneer het voor meerdere dieren in een koppel geldt) of op tochtigheid wanneer het individuele dieren betreft. De koppeling van uit sensor-informatie berekende attenties aan beeldmateriaal kan gebruikt worden om dergelijke interpretaties van gegevens van staartsensoren te valideren.

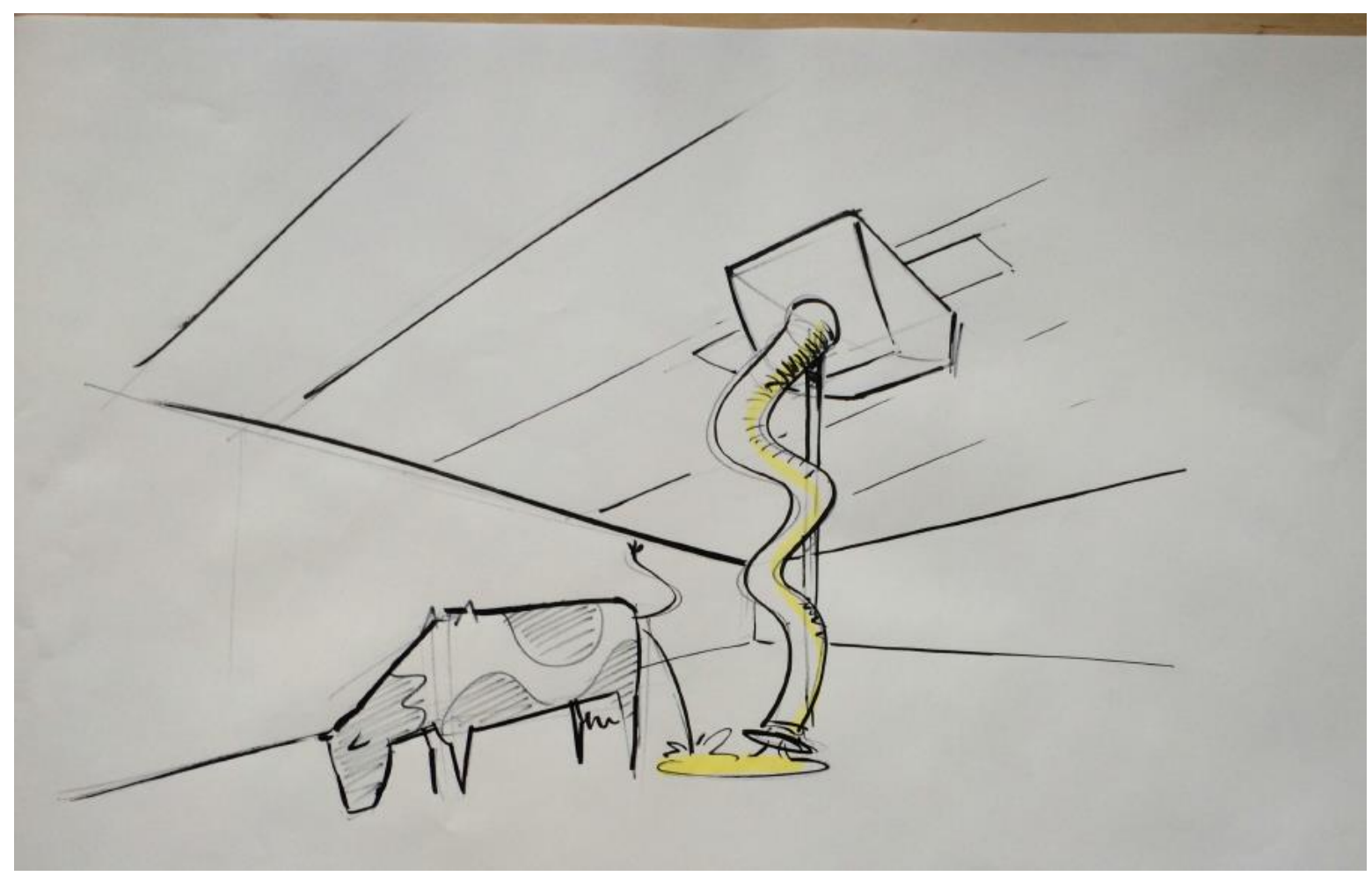




\section{$6 \quad$ Stimuleren van urineergedrag}

Sjoerd Bokma i.s.m. studenten Hogeschool Van Hall-Larenstein

\subsection{Inleiding}

Om de ammoniakemissie vergaand te beperken is directe opvang van verse urine (de grootste ammoniakbron) de meest effectieve optie. Doelstelling van dit deelonderzoek was: middels kleinschalige experimenten inzicht in het urineergedrag ontwikkelen en bepalen of er praktische externe stimuli zijn waarmee het urineergedrag bij koeien betrouwbaar kan worden opgewekt. Het gericht verzamelen van urine bij runderen gebeurt meestal middels een katheter (Kurien et al., 2004), maar dit kan een blaasinfectie veroorzaken. Dit opvangen gebeurt dan vaak voor onderzoeksdoeleinden. Ook gebeurt het verzamelen van urine wel door het ophangen van zakjes aan de koe. Ook dit werkt in sommige gevallen wel, maar het veroorzaakt ongerief voor de koe. Manieren om urine bij vrijlopende koeien op te vangen lijken niet ruim voorhanden. Beoogd wordt hier een doorbraak te bereiken, zodat mest en urine bij de bron gescheiden kunnen worden opgevangen en afgevoerd.

In 6.2 is de aanpak beschrevenen in 6.3 zijn de resultaten en ervaringen vastgelegd. In paragraaf 6.4 worden de eerste voorzichtige conclusies van dit verkennend onderzoek geduid.

\subsection{Aanpak}

In veertien kleinschalige praktijkexperimenten is het perineum van koeien met verschillende materialen kortstondig gemasseerd met als doel om urineergedrag op te wekken. Daarbij is gewerkt volgens een zelf ontwikkeld stimulatieprotocol (Van Dixhoorn, 2015, persoonlijke mededeling), zie paragraaf 6.3. In het experiment is gebruik gemaakt van een groep van zestig melkkoeien (zwarte- en roodbonte Holstein) op Dairy Campus. Het is een gemengde groep wat betreft de lactatiestadia, maar ook wat betreft de leeftijd van de koeien. De experimenten zijn elke keer om negen uur in de ochtend, na het melken, uitgevoerd. De meeste dieren staan dan rustig aan het voerhek te vreten. De stimulatie werd zo veel mogelijk door dezelfde personen uitgevoerd. In het experiment zijn vijf stimulatiematerialen gebruikt en is gekeken naar de tijd, het urineergedrag, de hoeveelheid verzamelde urine en het gedrag van het dier. Een stimulatie werd maximaal gedurende 60 seconden uitgevoerd. Als het dan nog niet tot resultaat had geleid, werd dit als een onsuccesvolle poging genoteerd. Ging de koe wel binnen de 60 seconden urineren dan werd het stimuleren op dat moment gestaakt.

\subsection{Stimulatieprotocol voor opwekken urineren}

Voor het experiment is het onderstaande protocol toegepast:

1. Zorg ervoor dat de koe gefixeerd is aan het voerhek, in de robot of in de krachtvoer box

2. Zorg ervoor dat de koe tijdens het opsluiten, vaststaan iets te vreten heeft (krachtvoer of ruwvoer) zodat de koe wordt afgeleid

3. Voorkom stress of ongerief voorafgaand en tijdens het stimuleren

4. Gebruik als stimulatiemethode een afwasborstel, gewone borstel, schuurspons, een doekje of föhn

5. Voor het opvangen van de urine, gebruik een maatbeker van 2 liter

6. Strijk met het stimulatiemateriaal over het perineum van de koe, raak de koe verder niet aan en maak veegbewegingen van boven naar beneden, stimuleer maximaal één minuut lang

7. Als de koe begint te urineren moet er door gestimuleerd worden, dus niet stoppen

8. Na het urineren de hoeveelheid urine noteren, de stimulatieduur tot aanvang van het urineren en het diernummer 


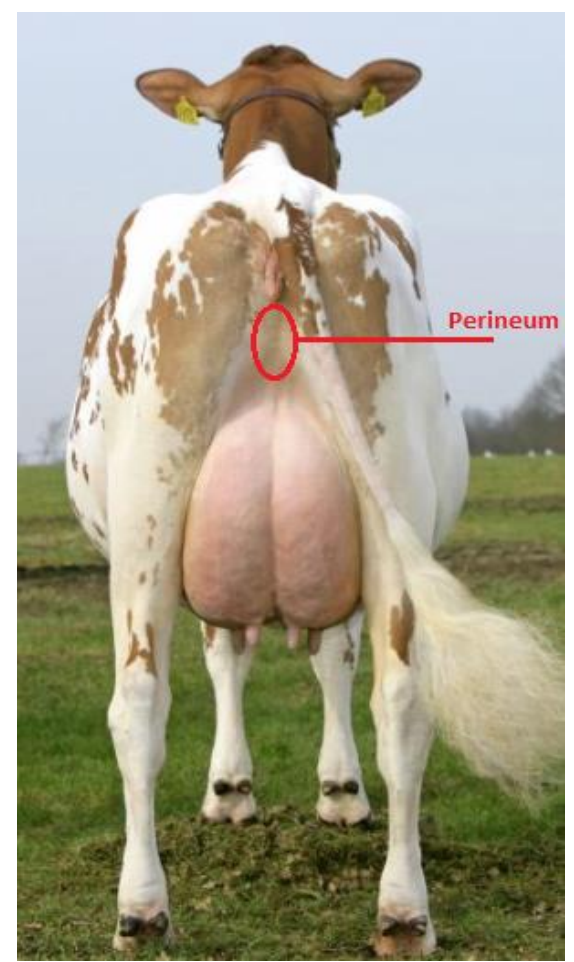

Figuur 10. Plaats van stimuleren.

\subsection{Welke externe stimuli hebben effect?}

In figuur 11 is te zien welke materialen er gebruikt zijn.

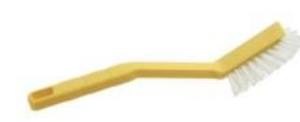

Afwasborstel

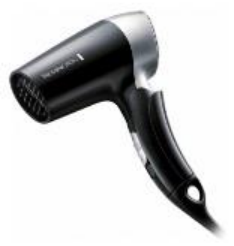

Föhn

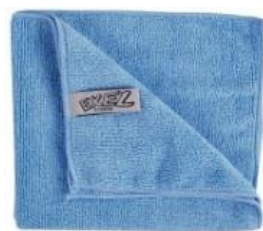

Doekje

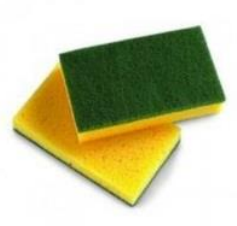

Schuurspons

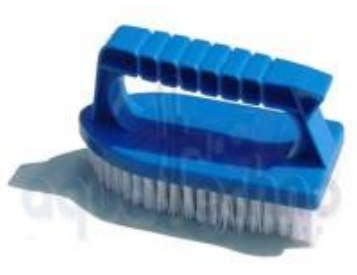

Grote borstel

Figuur 11. Gebruikte materialen of methode

In tabel 1 is het aantal gestimuleerde dieren weergegeven. Met de föhn waren de resultaten zodanig slecht dat het niet interessant was om die methode te herhalen. Het experiment met de grote borstel is één keer vaker uitgevoerd t.o.v. de afwasborstel, de schuurspons en het doekje.

Tabel 1. Aantal dieren en proefuitvoeringen per stimulatiemethode

\begin{tabular}{llllll} 
Methode & Afwas borstel & Grote borstel & Schuur spons & Doekje & Föhn \\
$\begin{array}{l}\text { Aantal } \\
\text { herhalingen }\end{array}$ & 3 & 4 & 3 & 3 & 1 \\
\hline $\begin{array}{l}\text { Aantal } \\
\text { koeien totaal }\end{array}$ & 129 & 185 & 103 & 131 & 30
\end{tabular}

In het onderzoek is in het totaal 578 keer een stimulatiehandeling uitgevoerd voor het opwekken van urineren. Hiervan hebben er 152 geresulteerd in een urineerrespons en 426 niet. Van alle stimulatiemethoden hebben dus gemiddeld $26,3 \%$ van de koeien geürineerd. In figuur 12 wordt duidelijk met welk stimulatiemateriaal de hoogste respons is behaald: $32 \%$ met de afwasborstel, gevolgd door de grote borstel met $28 \%$. De föhn gaf $0 \%$ respons. 


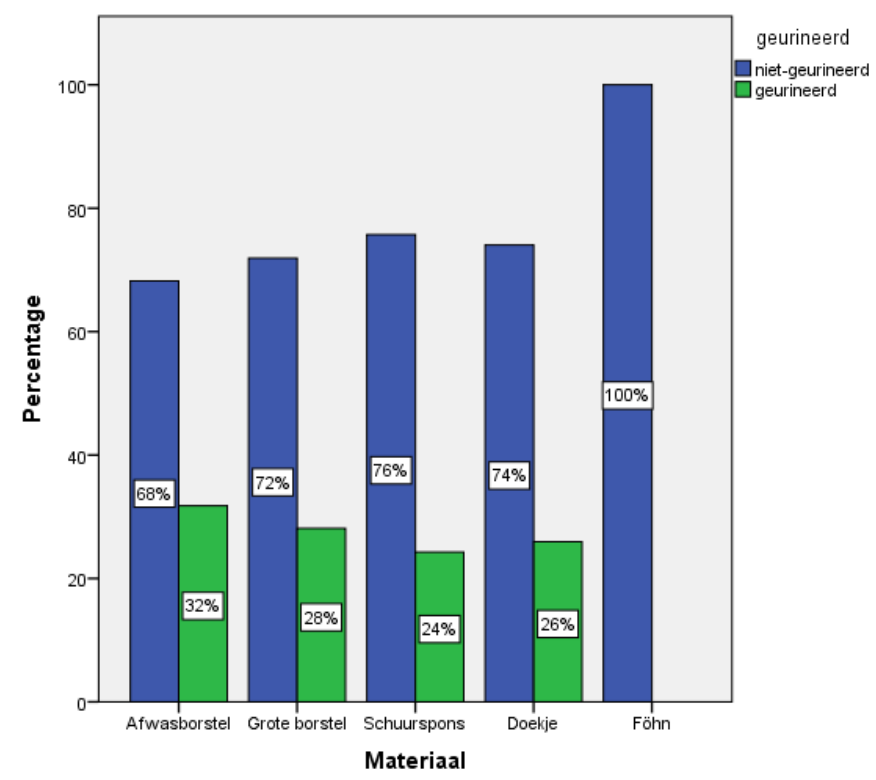

Figuur 12. Percentage dieren wel/niet geürineerd per stimulatiemateriaal.

In tabel 2 is weergegeven wat de gemiddelde reactietijd in seconden is per succesvolle stimulatie. De reactietijd van de luchtmassage met de föhn kon niet worden bepaald omdat daarmee geen succesvolle urinelozingen zijn opgewekt. De schuurspons laat van de succesvolle materialen de langste reactietijd zien. Op de drie andere materialen reageerden de koeien die gingen urineren even vlot en gingen na gemiddeld 25 seconden perineum massage urineren.

Tabel 2. Gemiddelde tijd (in seconden) tussen start stimuleren en aanvang urineren bijverschillende stimulatiematerialen

\begin{tabular}{ccccc}
\multicolumn{5}{c}{ Reactietijd urineergedrag } \\
\hline Afwasborstel & Grote borstel & Schuurspons & Doekje & Föhn \\
\hline $23,4 \mathrm{sec}$ & $24,5 \mathrm{sec}$ & $44,9 \mathrm{sec}$ & $24,6 \mathrm{sec}$ & Geen respons
\end{tabular}

Naast bovenstaande stimulatie van de perineum-zone is ook verkennend geprobeerd of het urineergedrag van koeien wordt opgewekt als ze een strobed krijgen aangeboden (is bij paarden vaak succesvol) of wanneer ze geluid van stromend water aangeboden krijgen (helpt vaak bij mensen). Op het geluid van stromend water werd door geen van de dieren met urineren gereageerd. Het beschikbaar stellen van een stukje stalruimte met strobed gaf zoveel enthousiasme bij de kudde dat er massaal gebruik van werd gemaakt om rond te dollen, maar niet om te urineren. Deze verkenning is daarom gestaakt.

Van iedere succesvolle urinelozing is de hoeveelheid geloosde urine bepaald. In figuur 13 zijn de gemiddelde hoeveelheden per stimulatiemateriaal weergegeven.

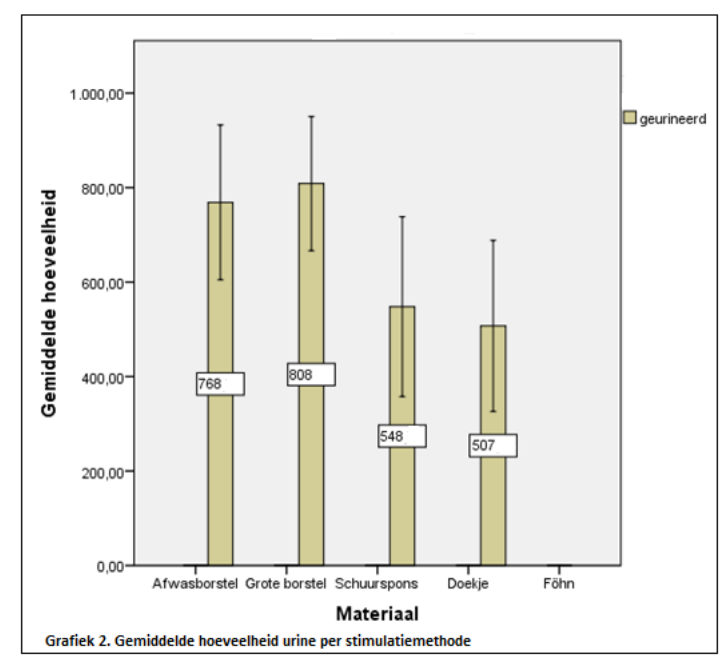

Figuur 13. Gemiddeld opgevangen hoeveelheid urine $(\mathrm{ml})$ per succesvolle stimulatie voor de 5 toegepaste stimuli. 
De gemiddelde opgevangen hoeveelheid per materiaal varieerde van $507 \mathrm{ml}$ tot $808 \mathrm{ml}$ per lozing, waarbij de afwasborstel en de grote borstel de gemiddeld grootste volumes scoorden.

In figuur 14 zijn de verzamelde hoeveelheden urine van elke uitgevoerde koe-stimulatie in de tijd uitgezet. Ook de stimulaties die niet tot een urinelozing leidden. Vervolgens is per experiment het gemiddelde lozingsvolume bepaald en als een lijn in de tijd uitgezet.

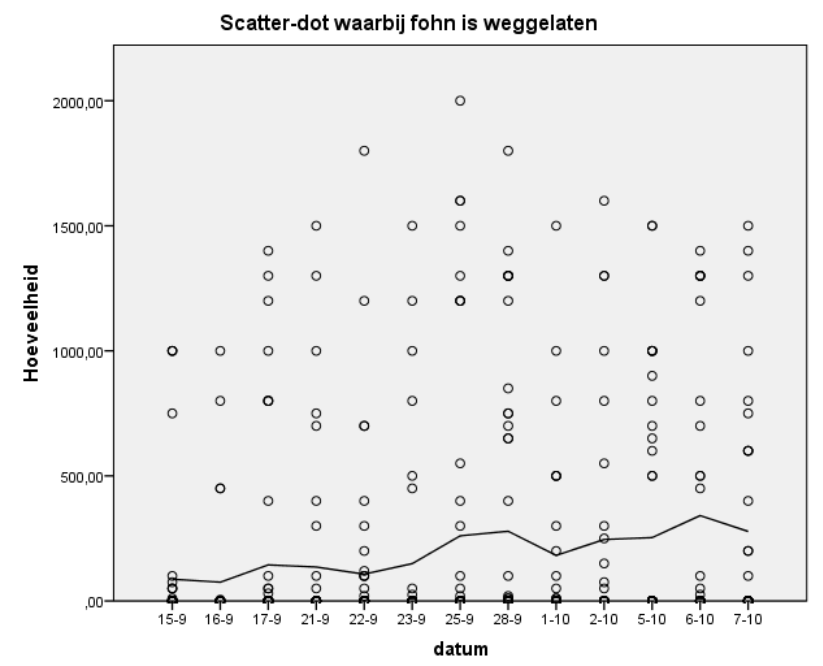

Figuur 14. Gemiddelde urineerrespons van alle koeien ( $\mathrm{ml} /$ koe) tijdens het verloop van de experimenten.

Tijdens het verloop van het onderzoek nam de gemiddeld opgevangen hoeveelheid urine per gestimuleerde koe geleidelijk toe. Dit kan wijzen op gewenning bij de koeien of een leereffect bij de stimulatoren.

\subsection{Voorlopige conclusies}

- $\quad$ Perineum-massage wekt het urineergedrag van runderen op.

- Het masseren van het perineum van de koe met een grove, vrij harde borstel (afwasborstel of gewone borstel), is de meest effectieve praktische externe stimulus waarmee urineergedrag van koeien kan worden opgewekt. Bij gemiddeld 32\% van de koeien kon hiermee urineergedrag worden opgewekt.

- $\quad$ Er dient fysiek perineumcontact met de koe te zijn om deze te laten urineren. Met de föhn (luchtstroom), het geluid van stromend water, of het plaatsen van koeien op een strobed was dat fysieke contact niet aanwezig en werd ook geen urineergedrag waargenomen. Als er aan een geautomatiseerde toepassing wordt gedacht, lijkt daarbij dus ook fysiek contact met het perineum nodig.

- De koe moet zich tijdens het stimuleren op haar gemak voelen. Dit kan worden bevorderd door bijvoorbeeld het verstrekken van ruwvoer of krachtvoer.

- $\quad$ Bij het stimuleren is er vaak resultaat binnen een tot enkele tientallen seconden of er gebeurt niets. Het doorzetten van het stimuleren langer dan een minuut lijkt weinig zinvol.

- De koeien reageren na verloop van tijd met snellere en betere respons op de massage. De koeien gingen vaker en in grotere hoeveelheden urineren, maar de verschillen in respons op de getoetste stimulatiematerialen bleven overeind.

- Tijdens het experiment ontstond de indruk dat er ook sprake is van een "mens-effect"; door bepaalde "masseurs" werden betere responses behaald dan anderen. 


\section{$7 \quad$ Ontwikkeling van een urineerbox}

Sjoerd Bokma en Helmer Ebbers

\subsection{Prototype}

In het voorjaar van 2016 heeft een proof of principle plaats gevonden bij een melkveehouder met een prototype urineerbox (een aangepast doorloopvoerstation) in een klein groepje droge koeien gedurende ongeveer 6 weken. In deze box werden de koeien geleerd en, in eerste instantie handmatig, gestimuleerd om te urineren. De box is ontwikkeld bij Ebbers Metalworks te Doetinchem. De urine werd opgevangen in een bakje aan de toegangspoort van de box, dat aansloot bij het achterwerk van de koe (figuur 15). De urine werd separaat opgevangen en de bak werd na elke urinelozing gespoeld. Bij een eliminatie (urineren of mesten) in het opvangbakje werden deze koeien direct beloond met 150 gram extra smakelijk krachtvoer. Tijdens de proef is de box voorzien van een stimulatiemechanisme, afgeleid van de kennis uit hoofdstuk 6 . Een camera legde alle gedragingen vast.

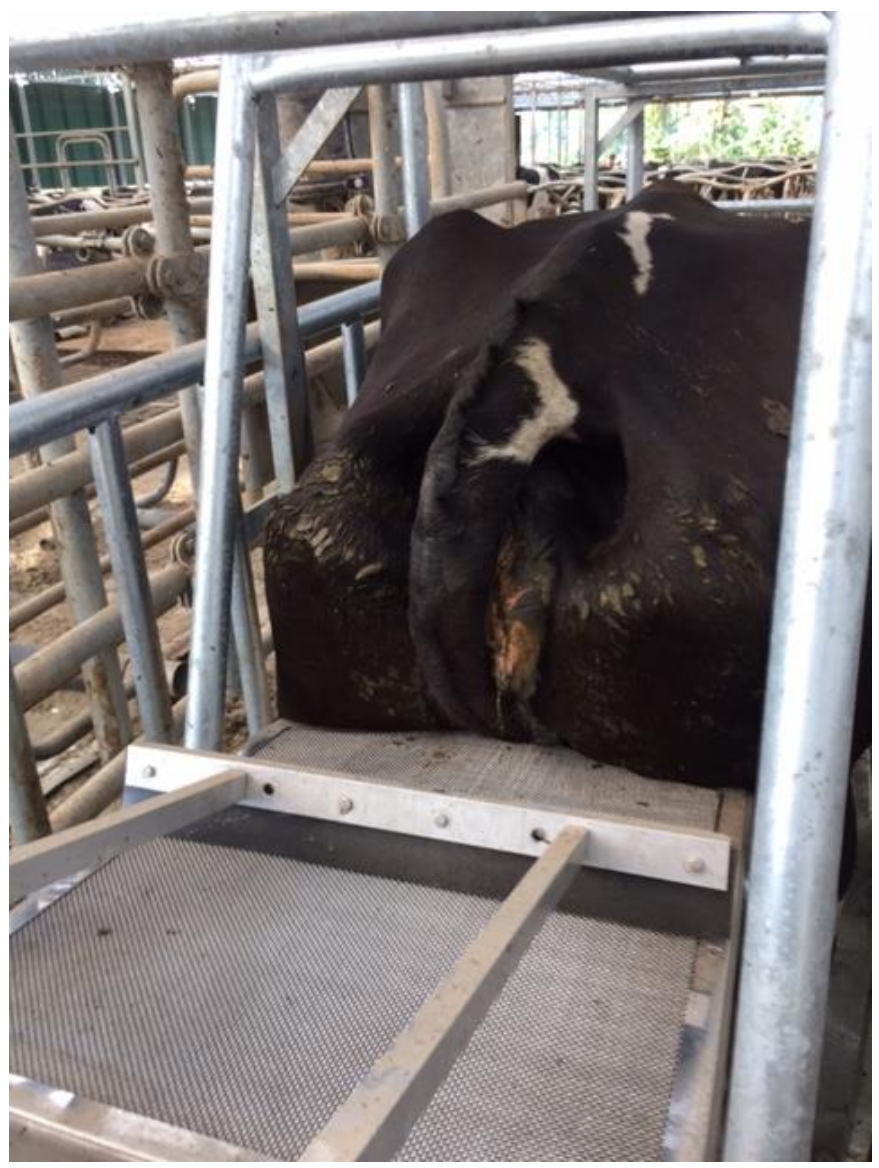

Figuur 15. De opvangbak in de prototype urineerbox.

In deze periode heeft een aantal droge koeien laten zien dat ze wel degelijk in staat zijn te urineren in een daartoe bestemde box. Het laat zich aanzien dat de koe leergedrag vertoont door een houding van urineren aan te nemen in de box. Als het stimuleermechanisme aanwezig is, is duidelijk zichtbaar dat de koeien zelf het mechanisme opzochten om te urineren en aansluitend een voerbeloning te krijgen. Zie daarvoor figuur 16, het verschil in bezoeken en urinelozingen voor en na 3 april. Uit deze groep deden twee droge koeien (koeien die al langer in de ruimte met de urineerbox stonden) het merendeel van hun urinaties in de urineerbox. Van alle bezoeken die koeien aan de urineerbox aflegden vond in tweederde deel daarvan een urinelozing (80\%) of een mestlozing (20\%) plaats. 


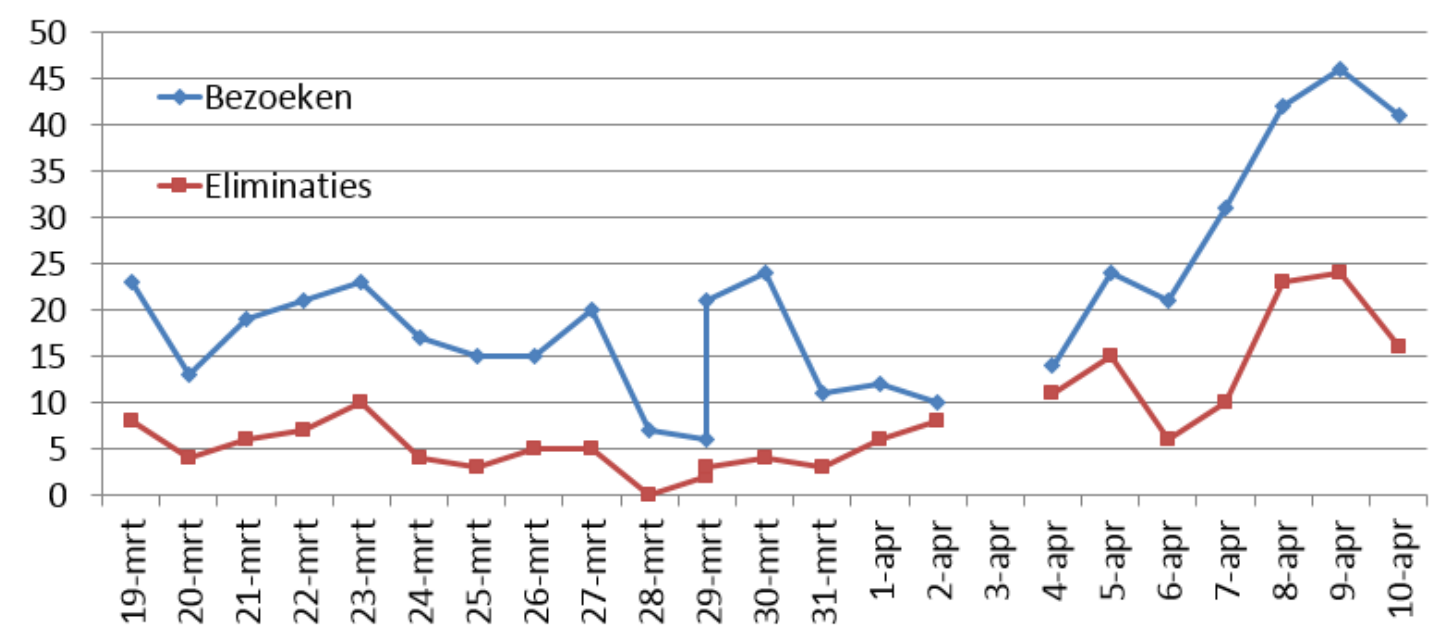

Figuur 16. Bezoeken en urinaties voor en na aanpassing van het prototype urineerbox.

\subsection{Praktijkverkenning met urineerbox}

In zomer 2016 is het prototype doorontwikkeld. Deze box is in najaar 2016 op een ander melkveebedrijf in de Achterhoek geplaatst. Ebbers Metalworks verrichtte daar vooral zelf het onderzoek naar het functioneren van deze box. De urine wordt nu op de dichte vloer van de urineerbox opgevangen en met behulp van een dompelpomp afgevoerd en buiten de stal in een afgesloten container opgeslagen. De waarnemingen richtten zich op het aantal dieren dat gebruik makt van de box, het aantal urinaties in de box en elders, de verdeling over de dag, de zuiverheid van de opgevangen urine en het type brok dat het beste werkt als beloning.

Gestart is met een groep van 10 koeien. In voorjaar 2017 is de groep uitgebreid naar 60 dieren. Doel is om meer dan 50 \% van de urinelozingen van de groep melkkoeien op te vangen. Bij het weiden blijkt het gebruik van de box terug te lopen. Verdere resultaten van deze praktijkverkenning worden door Ebbers Metalworks t.z.t. zelf naar buiten gebracht. Ook wordt door hen de urine verwerking ter hand genomen. 


\section{$8 \quad$ Urineerbox in milieukundig en economisch model}

Roland Melse en Izak Vermeij

\subsection{Massabalans}

Als urine en feces gescheiden opgevangen kunnen worden, geeft dit op bedrijfsniveau mogelijkheden om deze mestfracties "op maat" in te zetten. Het mestmanagement en de bewerking van mestproducten kan economische voordelen opleveren. Daarom is in dit hoofdstuk berekend wanneer een urineerbox in economische zin op bedrijfsniveau te implementeren is.

Om te beginnen is een stroomschema van het Urineerbox systeem gemaakt. De urine die uit het Urineerbox systeem komt, wordt in een stripper/verdamper omgezet in een stikstof arme vloeistof en een stikstofrijke spuiwaterstroom. Een deel van de urine zal in de praktijk niet in het Urineerboxsysteem terechtkomen maar in de mestkelder (of buiten tijdens weidegang). In figuur 17 wordt dit schematisch weergegeven.

PRODUCTIE MEST EN URINE MELKKOEIEN "ONDER DE STAART"

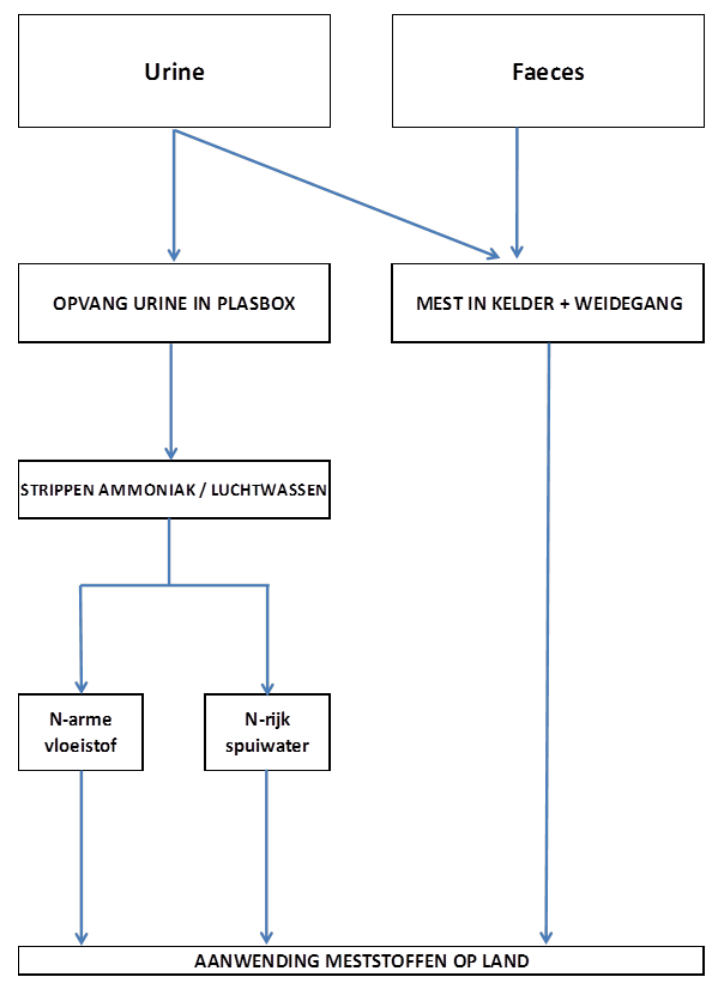

Figuur 17: Stroomschema urineerbox systeem.

De input-parameters van het massabalans-model zijn als volgt:

- aantal melkkoeien en hoeveelheid jongvee (zowel jonger als ouder dan 1 jaar);

- hoeveelheid eigen grasland en/of bouwland;

- maximale gift stikstof uit dierlijke mest (wel/geen derogatie) en uit kunstmest;

- maximale gift fosfaat en kali;

- deel van de koeien wat toegang heeft tot urineerbox-systeem;

- percentage benutting van urineerbox (hoeveel urine komt daadwerkelijk in urineerbox terecht);

- mate van beweiding (geen/alleen overdag/continu). 
Vervolgens wordt op basis van deze invoer een massabalans opgesteld voor het melkveebedrijf en wordt berekend welke consequenties toepassing van de urineerbox heeft voor de fosfaat-, stikstof- en kali-stromen van het bedrijf. Daaruit volgt bijvoorbeeld welk deel van de mest in het urineerboxsysteem terecht komt, welk deel in de mestkelder en welk deel buiten (beweiding) terecht komt. Ook wordt berekend tot welke verschuivingen dat leidt met betrekking tot mestaanvoer, mestafvoer, kunstmestaankoop etc. De basisgedachte hierbij is enerzijds dat het $\mathrm{N}$-rijke spuiwater uit het urineerbox systeem kan worden aangewend als kunstmestvervanger en niet (meer) wordt gezien als dierlijke mest. Anderzijds kan het $\mathrm{N}$-rijke spuiwater, in vergelijking met drijfmest, tegen lagere kosten worden afgevoerd van het bedrijf indien er meer geproduceerd wordt dan er op eigen bedrijf kan worden toegepast. Op deze manier kunnen dus verschillende varianten worden doorgerekend. Ook blijft het natuurlijk mogelijk om geen kunstmestvervanger te produceren en de gescheiden dierlijke mestproducten op het grasland aan te wenden.

Ter illustratie wordt in figuur 18 voor een melkveebedrijf met 48 ha (40 ha grasland en 8 ha maisland) weergegeven wat de impact is van het toepassen van het urineerbox systeem, afhankelijk van het aantal melkkoeien. Er wordt in dit specifieke voorbeeld aangenomen dat $75 \%$ van de melkkoeien op het urineerbox systeem zit en (volgens de Programmatische Aanpak Stikstof) 720 uur per jaar, minimaal 3 uur /dag, beweiding wordt toegepast. Aangenomen wordt dat per ha grasland $230 \mathrm{~kg} \mathrm{~N}$ uit dierlijke mest mag worden toegepast. Figuur 18 laat zien dat zowel voor een traditionele stal als voor een stal met urineerbox systeem geldt dat de hoeveelheid af te voeren mest toeneemt (uitgedrukt als ton $\mathrm{N}$ per jaar) met een toenemend dieraantal. Maar toepassing van het urineerbox systeem leidt er toe dat er minder mest behoeft te worden afgevoerd (zwarte lijn) dan in de referentiesituatie zonder urineerbox (blauwe lijn). Daarnaast leidt het urineerbox systeem ertoe dat minder kunstmest hoeft te worden aangekocht (gele en rode lijn), omdat uit de urine een kunstmestvervanger ("spuiwater") wordt gemaakt (groene lijn).

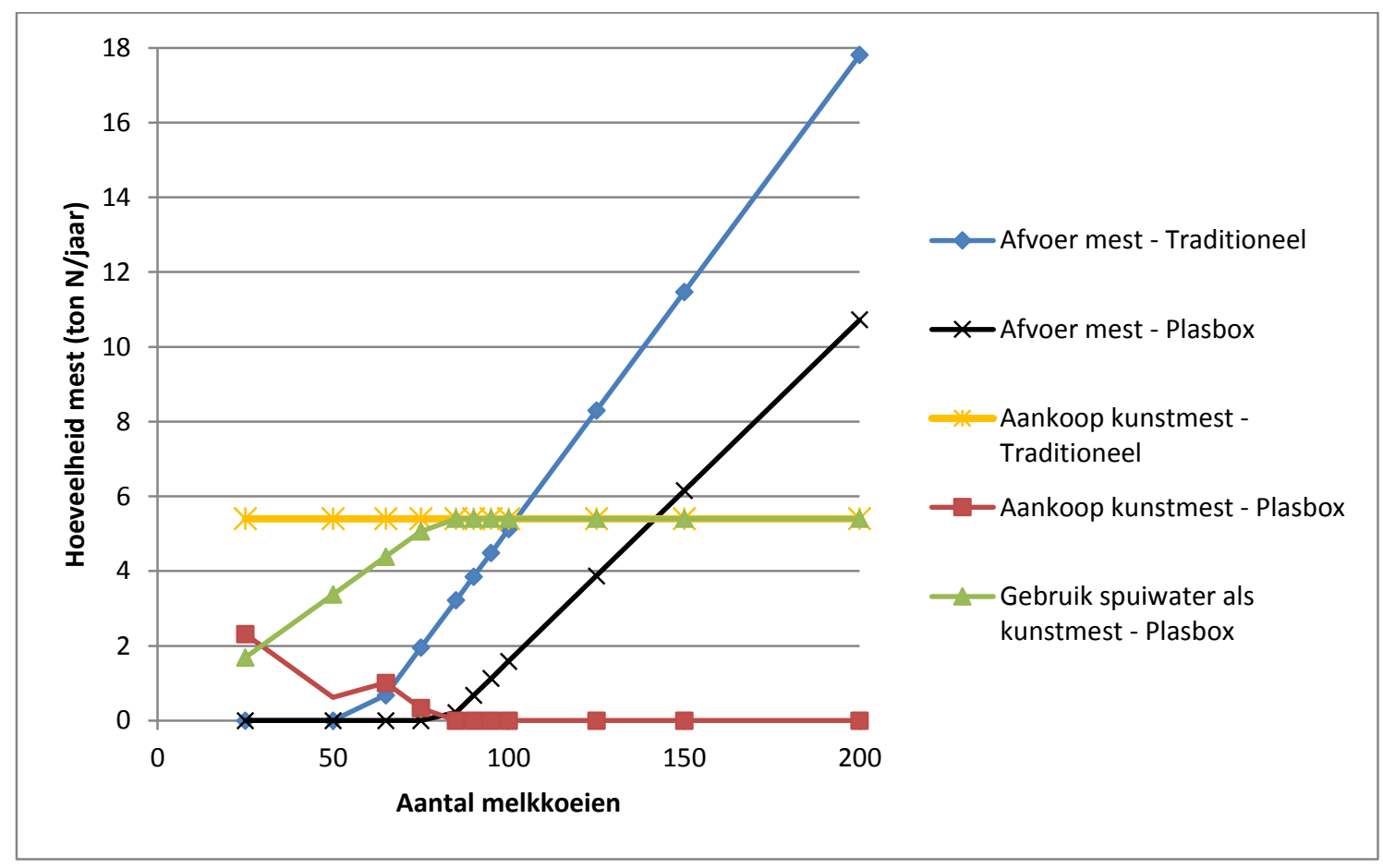

Figuur 18. Effect van gebruik van urineerbox systeem op stikstofbalans bedrijf (uitgaand van 40 ha grasland en 8 ha maisland) met derogatie, d.w.z. maximaal $230 \mathrm{~kg} \mathrm{~N} / \mathrm{ha}$ grasland uit dierlijke mest.

Vervolgens wordt in figuur 19 aangegeven wat het afschaffen van derogatie tot gevolg heeft, dat wil zeggen dat de maximale stikstofgift uit dierlijke mest wordt verlaagd tot $170 \mathrm{~kg} \mathrm{~N} / \mathrm{ha}$ grasland.

Uit vergelijking van figuur 18 en figuur 19 blijkt dat de kunstmestbehoefte sterk toeneemt wanneer derogatie wordt afgeschaft, de reden hiervoor is dat er minder dierlijke mest mag worden aangewend. Het gevolg hiervan is dat er ook meer spuiwater uit het urineerboxsysteem kan worden gebruikt als kunstmestvervanger en er minder spuiwater behoeft te worden afgevoerd. 


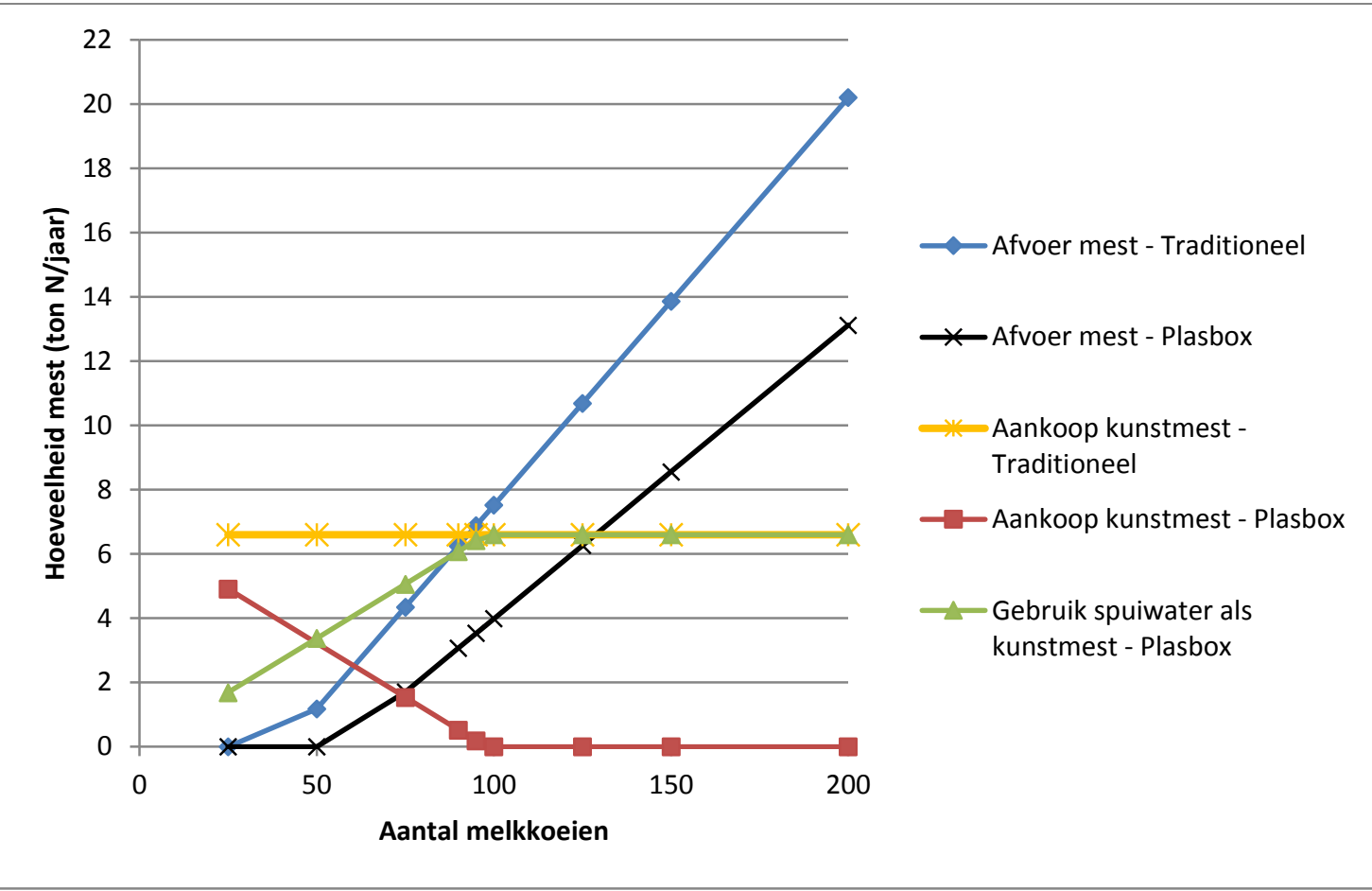

Figuur 19. Effect van gebruik van urineerbox systeem op stikstofbalans bedrijf (uitgaand van 40 ha grasland en 8 ha maisland) zonder derogatie, d.w.z. maximaal $170 \mathrm{~kg} \mathrm{N/ha} \mathrm{grasland} \mathrm{uit}$ dierlijke mest.

\subsection{Economische berekeningen}

Op basis van de massabalans, zijn economische berekeningen gemaakt voor de toepassing van de urineerbox. Hierbij is rekening gehouden met de investeringen voor de urineerbox, de stripper en de extra opslagcapaciteit voor $\mathrm{N}$-arme urine en spuiwater. Ook is gerekend met de jaarkosten die van deze investeringen zijn afgeleid, zijnde rente, afschrijving en onderhoud. Daarnaast is in de economische berekening rekening gehouden met de prijs voor mestafzet en eventuele aanvoerkosten, kosten voor aanwenden van mest, prijs van kunstmest, chemicaliën en afzet van spuiwater. Als referentie geldt een bedrijf met 100 melkkoeien, met een veebezetting van 2,5 melkkoe/ha, maximale $\mathrm{N}$-gift van $230 \mathrm{~kg} / \mathrm{ha}$, mestafzetprijs van $€ 18$ per $\mathrm{m}^{3}$ en luchtwassing met salpeterzuur ${ }^{1}$.

Behalve voor een standaardsituatie, is het economisch resultaat voor een aantal scenario's berekend. In deze scenario's is gevarieerd met veedichtheid, mestafzetprijs, investeringen, maximale aanwending dierlijke mest, aankoop Kali en het wassen met citroenzuur in plaats van salpeterzuur. Hieruit is een soort optimum combinatie scenario gekozen, waarbij van de voorgaande scenario's de variant met het beste economische resultaat is genomen.

In bijlage 2 staat een overzicht van de uitgangspunten en het resultaat van de scenario's. In de referentie situatie ontstaat een resultaat van $€ 4.861$ per jaar. De mestafzetprijs heeft de meeste invloed op het resultaat. Als deze prijs wordt verhoogd van $€ 18$ naar $€ 25$ per $\mathrm{m}^{3}$, ontstaat een positief resultaat van $€ 9.400$. Ook het verlagen van de investeringen met een derde leidt tot een gunstiger resultaat. Met een combinatie van een hogere veedichtheid, hogere mestafzetprijs en lagere investeringen, kan een positief resultaat van $€ 12.540$ per jaar ontstaan. Bij lage mestafzetprijs of gebruik van zwavelzuur in plaats van salpeterzuur, ontstaat een negatief resultaat. In figuur 19 staat het financiële resultaat van de verschillende scenario's. Het grootste effect ligt bij de mestafzet prijs.

\footnotetext{
${ }^{1}$ Normaliter wordt zwavelzuur gebruikt in de luchtwasser, maar dan zou het spuiwater teveel zwavel bevatten en afgevoerd moeten worden, waarvoor in de plaats weer kunstmest aangekocht moet worden
} 


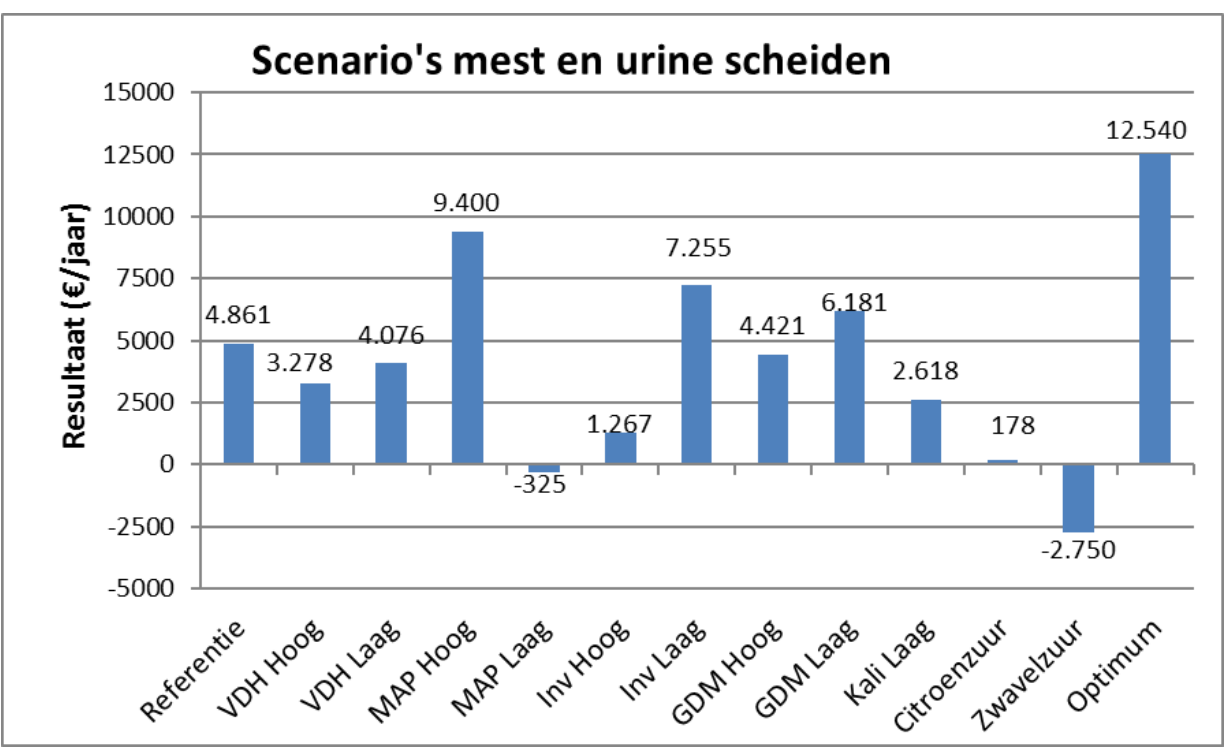

Figuur 20. Economisch resultaat van toepassing urinescheiding in verschillende scenario's $(\mathrm{VDH}=$ Veedichtheid, MAP = Mestafzetprijs, Inv = Investeringen, GDM = Gift dierlijke mest, Kali laag= geen kali kunstmest meer gebruiken).

In figuur 21 wordt het economische resultaat van het scheiden van mest en urine afgezet tegen de mest-afzetprijs. Dit blijkt een lineaire lijn te geven, waarbij het omslagpunt rond $€ 10,50$ per ton mest ligt bij het gebruik van salpeterzuur. Bij het gebruik van zwavelzuur in de luchtwasser, ligt het omslagpunt bij $€ 22$ per ton mest. Boven deze omslagpunten wordt het economisch resultaat positief. Dat het aantrekkelijker is om salpeterzuur te gebruiken, komt omdat de extra N- aanvoer via salpeterzuur een besparing oplevert voor de aanvoer van $\mathrm{N}$ via kunstmest.

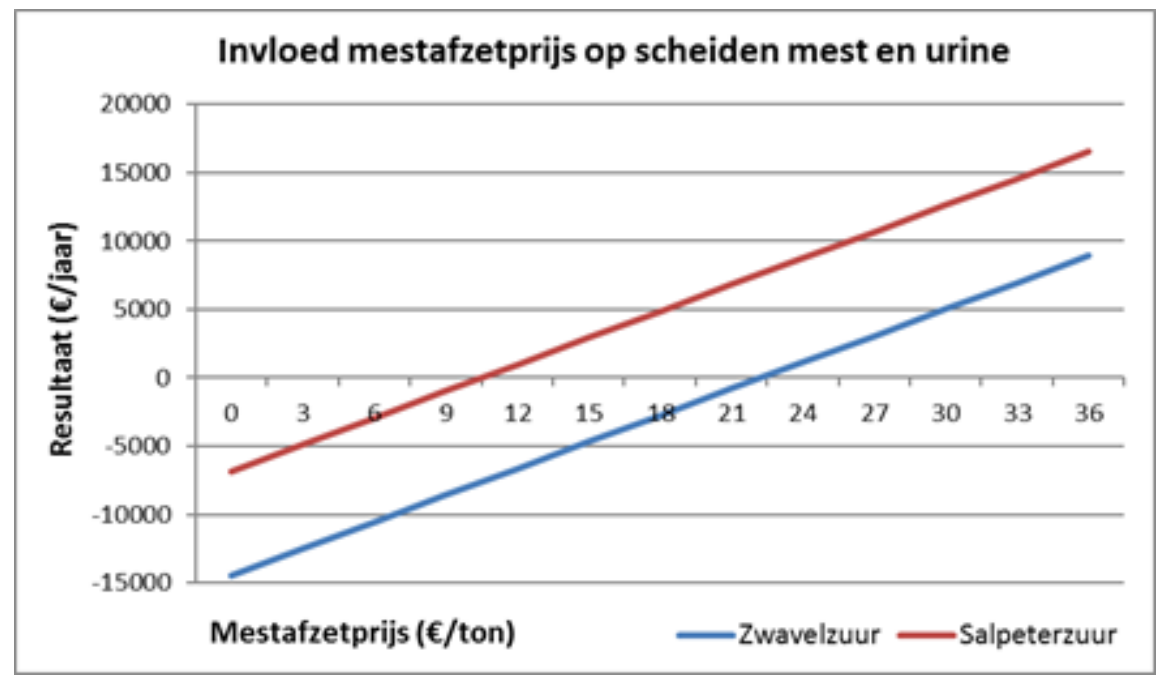

Figuur 21. Relatie resultaat scheiding mest en urine en mestafzetprijs

In de referentie is het uitgangspunt dat van $75 \%$ van de melkkoeien de mest en urine gescheiden worden. Bij oplopend aandeel melkkoeien waarbij wordt gescheiden, neemt het economisch resultaat toe, zoals uit figuur 22 blijkt. 


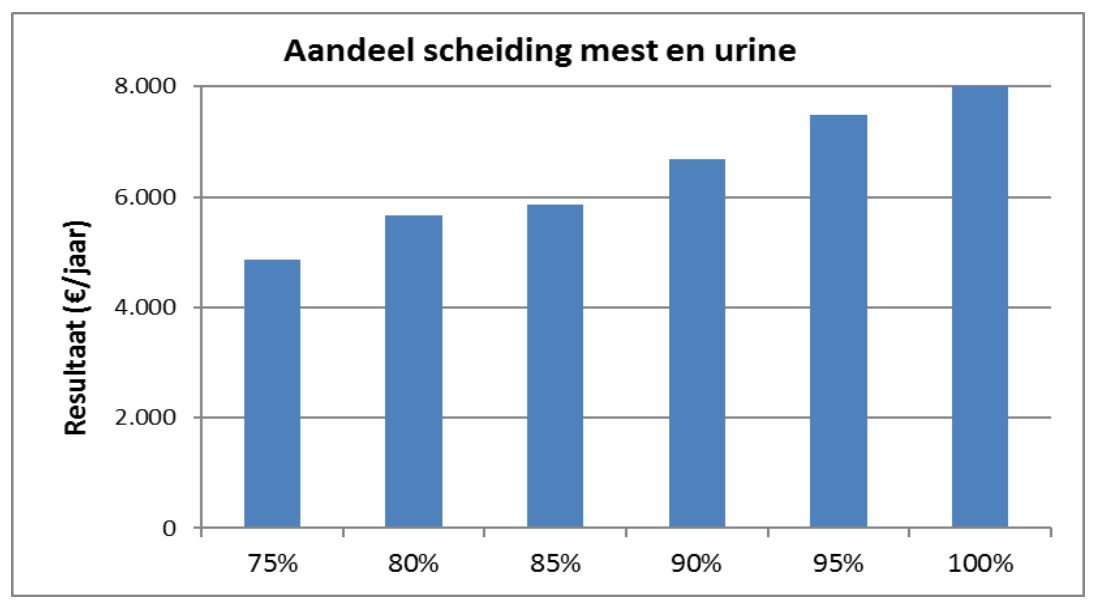

Figuur 22: Relatie resultaat scheiding mest en urine en aandeel melkkoeien met scheiding. 


\section{Berekening perspectief $\mathrm{NH}_{3}-$ emissiereductie}

Hendrik Jan van Dooren

\subsection{Achtergrond}

Ammoniakemissie uit melkveestallen is het resultaat van een aantal processen die starten bij de urine van koeien. Urine bevat ureum $\left(\mathrm{CH}_{4} \mathrm{~N}_{2} \mathrm{O}\right.$ of ook wel $\left.\mathrm{CO}\left(\mathrm{NH}_{2}\right)_{2}\right)$, een stikstofverbinding. Mest (feces) bevat bacteriën die het enzym urease produceren. Op alle met mest bevuilde oppervlakken is dit enzym in grote overvloed aanwezig. De urease-activiteit wordt uitgedrukt in de snelheid waarmee ureum wordt omgezet in ammonium uitgedrukt in: $\mathrm{mg} \mathrm{NH}_{4}{ }^{+} / \mathrm{m}^{2} . \mathrm{s}^{-1}$ ). Stap 1 in het proces dat leidt tot ammoniakemissie is dus de omzetting van ureum in ammonium:

$\mathrm{CO}\left(\mathrm{NH}_{2}\right)_{2}+2 \mathrm{H}_{2} \mathrm{O} \rightarrow 2 \mathrm{NH}_{4}+\mathrm{CO}_{2}+\mathrm{H}_{2} \mathrm{O}$

Stap 2 is het evenwicht tussen ammonium en ammoniak. Ammonium $\left(\mathrm{NH}_{4}{ }^{+}\right)$is in evenwicht met ammoniak dat opgelost is in water $\left(\mathrm{NH}_{3}(\mathrm{I})\right)$ :

$\mathrm{NH}_{4}{ }^{+} \leftrightarrow \mathrm{NH}_{3}(\mathrm{I})+\mathrm{H}^{+}$

Dit evenwicht kan opschuiven richting ammoniak of ammonium. Een belangrijke factor daarbij is de zuurtegraad $(\mathrm{pH})$. Bij lage $\mathrm{pH}$ (zuur) schuift het evenwicht richting ammonium, bij hoge pH (basisch) schuift het evenwicht richting ammoniak. Bij pH 5 en lager ligt het evenwicht helemaal naar links $\left(\mathrm{NH}_{4}^{+}\right)$en is in de vloeistof geen vervluchtigbare ammoniak aanwezig.

Stap 3 is het evenwicht van in water opgelost en gasvormig ammoniak. Ammoniak is relatief gemakkelijk oplosbaar in water maar in evenwicht met gasvormig ammoniak:

$\mathrm{NH}_{3}(\mathrm{l}) \leftrightarrow \mathrm{NH}_{3}(\mathrm{~g})$

Wanneer de concentratie in de luchtlaag net boven het vloeistofoppervlak laag is verschuift het evenwicht richting gasvormig ammoniak.

Wanneer een hoeveelheid ammonium/ammoniakvloeistof zich in een afgesloten ruimte bevindt, zal zich een evenwicht tussen gasvormig en opgelost ammoniak instellen. De lucht boven het oppervlak is op een gegeven moment verzadigd ( $\mathrm{vol}$ ) met ammoniak. Er verdwijnt geen ammoniak meer uit de vloeistof. Dit evenwicht kan beïnvloed worden door luchtbeweging boven het vloeistofoppervlak. Door de luchthoeveelheid steeds te verversen (wat bij ventilatie het geval is) blijft er ammoniak uit de vloeistof treden.

\subsection{Praktische consequenties}

Deze hierboven beschreven processen spelen zich allemaal af in een urineplas die op een vloer terecht komt. Als de urine de koe verlaat is de stikstof in de urine voor bijna $100 \%$ aanwezig als ureum. Zodra de urine de vloer raakt begint de omzetting naar ammonium (stap 1). Er is zoveel ureaseactiviteit op een vloer dat dit proces maar korte tijd (0,5-1,0 uur) de beperkende factor in het hele proces is. Daarna is er zoveel ammonium aanwezig dat de snelheid van omzetting van de rest van de ureum er niet meer toe doet. Door urine snel af te voeren wordt dus niet de omzetting in ammonium geremd of vertraagd, maar wordt urine zo snel mogelijk in een compartiment gebracht (meestal de kelder) waar minder gunstige omstandigheden heersen voor de andere twee stappen die tot vervluchtiging leiden (afgesloten, aangezuurd, verdund, etc.). Aanzuren doet het evenwicht richting ammonium verschuiven. $\mathrm{Er}$ is geen of minder ammoniak beschikbaar om te emitteren. Afsluiting van de kelder betekent dat het gasvormige ammoniak minder makkelijk kan worden afgevoerd. De concentratie ammoniak in de kelder neemt dus toe en daarmee komt de uittreding van ammoniak uit 
vloeistof naar gasfase tot stilstand (of wordt verminderd). Het verminderen van de luchtbeweging in de stal en over de vloer (ACNV) heeft in theorie dezelfde werking. Door urine op te vangen in een (relatief schone) urineerbox wordt omzetting in ammonium vertraagd en kan de urine snel uit de stal worden afgevoerd en afgesloten opgeslagen worden.

\subsection{Emissiemodel}

Deze stappen zijn gemodelleerd tot een ammoniakemissie model (Monteny et al., 1998). Dat model gaat uit van één urineplas op een stalvloer en rekent aan de verschillende hierboven beschreven stappen. Door de emissie per plas voor de verschillende plassen bij elkaar op te tellen volgt een stalemissie of een emissie per koe. Hoeveel plassen er op de vloer komen en of deze plassen over elkaar heen worden gelegd of in het geheel kunnen 'leeg' emitteren hangt af van het beschikbare oppervlak per koe en de urinefrequentie. Wat de emissiepotentie van een urineplas is hangt af van de ureumconcentratie (te beïnvloeden met voeding) en het volume van de urineplas. Het volume van de plas is in het model opgenomen als plasoppervlak maal plasdikte. In het model zijn veel parameters opgenomen, maar de meeste zijn echter niet belangrijk in het kader van dit project omdat ze niet beïnvloed worden door de voorgestelde maatregelen. In het model zijn daarom voor die parameter standaardwaarden gekozen. In onderstaande berekeningen is uitgegaan van een referentie emissie van $11 \mathrm{~kg} \mathrm{NH}$ per dier per jaar.

\subsection{Effect opvangen van urine en gevolgen voor ammoniakemissie}

Het opvangen van urine is niet direct door te rekenen in het ammoniakemissie model. Er zal met de parameters urineerfrequentie, plasgrootte en plasdikte gevarieerd moeten worden. Daarbij zijn twee scenario's opgesteld. Eerste is het trainingsscenario. Dat gaat ervan uit dat uiteindelijk de koe in staat is om eigen gedrag te veranderen en te urineren op vaste plekken waar de urine wordt opgevangen. Aangenomen is dat dit niet van invloed zal zijn op de hoeveelheid urine per urinelozing. Het enige verschil tussen de huidige en de gewenste situatie is dat een koe naar een bepaalde plek loopt om te urineren. Dat kan natuurlijk meer of minder succesvol zijn. Het standaard aantal urinaties in het model is 10 per dag. Deze waarde is gevarieerd door het in stappen van 2 af te laten nemen tot 2 lozingen op de vloer per dag. De rest van de urinelozingen wordt dus opgevangen en leidt niet tot ammoniakemissie. Het tweede is een stimulatiescenario. Daarin wordt een urinelozing opgewekt wanneer een koe zich meldt op een bepaalde plaats (de urineerbox). Ook dat kan meer of minder succesvol zijn. Er kunnen nog steeds enkele urinelozingen op de vloer plaatsvinden. Maar het is ook aannemelijk dat het volume per lozing beïnvloed wordt. Daarom is in dit scenario niet alleen op dezelfde manier gevarieerd in het aantal lozingen per dag maar ook in de plasdikte. Er zijn ook nauwelijks gegevens beschikbaar over plasgrootte in de praktijk. Aangenomen is dat de plasgrootte gelijk blijft en dat de volumevermindering dus uitgedrukt wordt in de plasdikte. Het ingestelde urinevolume dat op de vloer achterblijft is 0,19-0,23-0,38-0,46 liter per lozing.

Tenslotte zijn beide scenario's uitgevoerd bij verschillend oppervlak per dier en bij twee vloertypen. Het oppervlak per dier is gevarieerd van 3,5 tot $5,0 \mathrm{~m}^{2}$ per dier in 4 stappen van $0,5 \mathrm{~m}^{2}$. Het vloertype komt tot uitdrukking in de kelderbijdrage (bij dichte vloeren is de kelder - gedeeltelijk afgesloten). Gekozen is voor een standaard roostervloer (100\% kelderbijdrage) en een sleufvloer (20\% kelderbijdrage). Daarbij is ervan uitgegaan dat de koeien het hele jaar binnen blijven. In de tijd dat de dieren buiten zijn zal de frequentie waarmee een urineplas op de vloer gevormd wordt ook afnemen. Om niet beide effecten door elkaar te laten lopen, geven de berekeningen het effect waarbij geen weidegang wordt geboden. Daarmee wordt het maximale effect van deze maatregelen duidelijk. Dit betekent echter niet dat in deze scenario's weidegang niet mogelijk of niet gewenst zou zijn.

\subsection{Resultaten}

In tabel 3 is de ammoniakemissie in $\mathrm{kg}$ per dier per jaar weergegeven voor verschillend oppervlak per dier en urineerfrequentie. De emissie neemt iets toe wanneer het oppervlak per dier toeneemt. 
Tabel 3. Berekende ammoniakemissie ( $\mathrm{kg} / \mathrm{dier} / \mathrm{jaar})$

\begin{tabular}{crrrrr} 
& \multicolumn{5}{c}{ Urineerfrequentie (lozingen/dag) } \\
Oppervlakte per dier $\left(\mathrm{m}^{2}\right)$ & $\mathbf{2}$ & $\mathbf{4}$ & $\mathbf{6}$ & $\mathbf{8}$ & $\mathbf{1 0}$ \\
$\mathbf{3 , 5}$ & 5,1 & 6,7 & 8,2 & 9,7 & 11,1 \\
\hline $\mathbf{4 , 0}$ & 5,5 & 7,1 & 8,7 & 10,2 & 11,7 \\
\hline $\mathbf{4 , 5}$ & 6,0 & 7,6 & 9,2 & 10,7 & 12,2 \\
\hline $\mathbf{5 , 0}$ & 6,5 & 8,1 & 9,7 & 11,3 & 12,8
\end{tabular}

In figuur 23 wordt het effect van minder lozingen weergegeven afgezet tegen de standaardwaarde van 10 lozingen per dag voor de verschillende oppervlakken per dier.

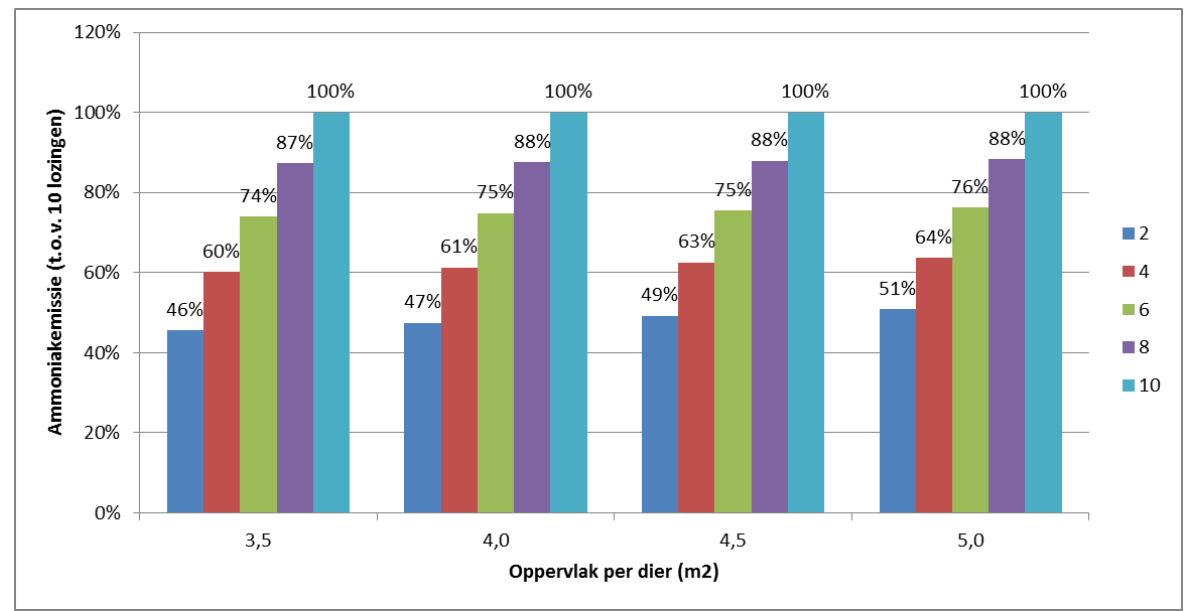

Figuur 23. Effect van lozingsfrequentie op ammoniakemissie (afhankelijk van dieroppervlakken).

Hieruit blijkt dat het effect van beperking van het aantal lozingen groot is. Ammoniakemissie wordt tot $50 \%$ beperkt als het aantal lozingen teruggebracht wordt tot 2 per dag. Er is een kleine invloed van het aantal $\mathrm{m}^{2}$ dat per dier beschikbaar is maar dat is maximaal $5 \%$. Dat komt doordat de kans dat een urineplas wordt weggespoeld door een volgende (en dus de emissie uit die plas wordt afgebroken) bij minder ruimte per dier groter is dan bij meer ruimte per dier.

Ingewikkelder wordt het als ook het urinevolume en vloertype wordt meegenomen. In figuur 24 zijn beide effecten weergegeven.

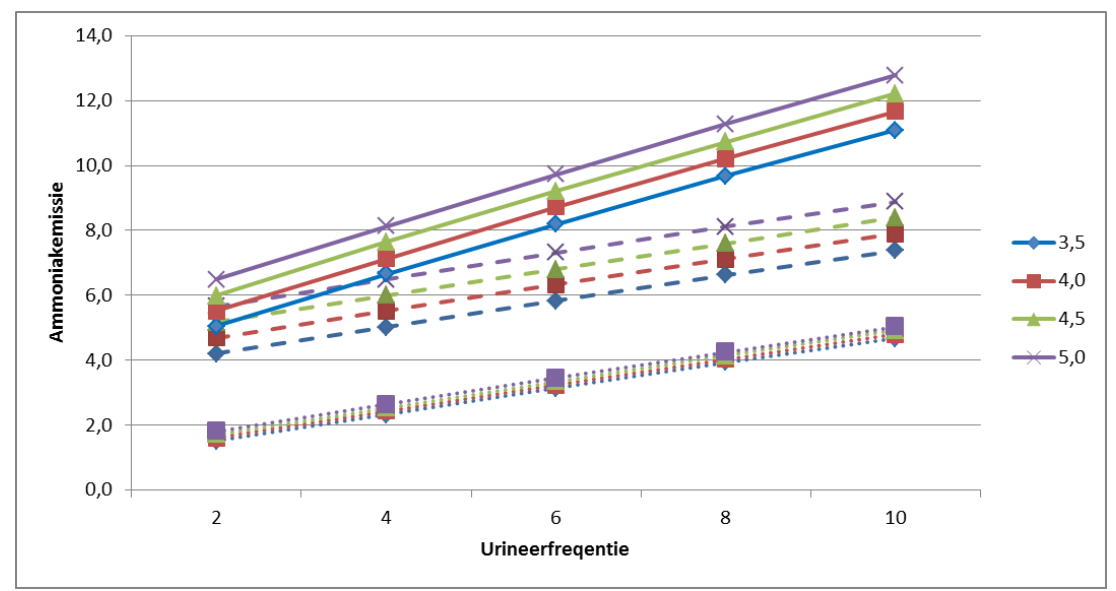

Figuur 24. Berekende ammoniakemissie bij verschillende urineerfrequenties.

De kleurtjes van de verschillende lijnen geven het oppervlak per dier aan. De doorgetrokken lijnen zijn van een roostervloer met standaard urinevolume (vergelijkbaar met staafdiagram in trainingsscenario). De gestreepte lijnen geven het effect van een halvering van het urinevolume weer (nog steeds op roostervloer). De gestippelde lijnen geven de halvering van urinevolume op een dichte vloer weer (veel minder kelderemissie). 
Tenslotte is in tabel 4 het totale effect van de verschillende opties als enkelvoudige maatregelen weergegeven. Daaruit blijkt dat het verminderen van de urineerfrequentie het meeste resultaat geeft op de ammoniakemissie, namelijk een reductie van $56 \%$.

Tabel 4. Resultaat van enkelvoudige maatregelen op de ammoniakemissie

\begin{tabular}{lll}
\multicolumn{1}{c}{ Effect van } & Waarden & Emissie t.0.V. referentie \\
urineerfrequentie & Van 10 naar 2 lozingen per dag & $44 \%$ \\
\hline oppervlak & Van 3,5 naar 5,0 $\mathrm{m}^{2}$ per dier & $117 \%$ \\
\hline urinevolume & Van 0,38 naar 0,19 liter per lozing & $68 \%$ \\
\hline vloertype & Van roosters naar sleufvloer & $58 \%$ \\
\hline
\end{tabular}




\section{Maatschappelijke acceptatie en effectiviteit van een urineerbox}

Hans Hopster

\subsection{Aanleiding vraag}

Omdat de relatie tussen mens en dier de laatste decennia is veranderd, leiden technologische ontwikkelingen in de veehouderij in toenemende mate tot kritische beschouwingen en tot negatieve beeldvorming in de samenleving. Die kritiek richt zich op de gevolgen van technologie voor het welzijn van dieren, maar ook op de wijze waarop dieren daardoor in toenemende mate als productiemiddelen worden beschouwd ('verdingelijking'). Terwijl de samenleving er juist steeds meer van overtuigd raakt dat dieren ('net als mensen') wezens met gevoel zijn die met respect behandeld dienen te worden. Dit leidt tot spanningen en onherroepelijk tot de vraag of het middel - het toilet voor koeien - het doel reductie van ammoniak - wel heiligt, temeer als er ook alternatieven zijn. Behalve technische, spelen dus ook maatschappelijke overwegingen een belangrijke rol bij een besluit om een 'proof of concept' door te ontwikkelen tot een vermarktbaar product. Om een dergelijk besluit beter te kunnen onderbouwen, wordt het volgende onderzoek voorgesteld:

- Publieksonderzoek naar de maatschappelijke acceptatie van het gebruik van een closet voor koeien, gekoppeld aan zindelijkheidstraining (de maatschappelijke waarden);

- Praktijkonderzoek naar de effectiviteit van het gebruik van het koeiencloset in het kader van ammoniakreductie (de praktijkvoordelen);

- Funderend onderzoek naar de effecten van het gebruik van het closet op het welzijn van koeien (de biologische feiten).

\subsection{Korte toelichting onderzoek}

Oordelen over het wel of niet acceptabel zijn van bepaalde praktijken zijn idealiter gebaseerd op een integrale afweging van de wetenschappelijke kennis (relevant, actueel) en de maatschappelijke moraal (intuïties, principes, feiten), volgens de RDA (2010). Om te kunnen schatten hoe voor de urineerbox een dergelijke afweging zal uitpakken wordt voorgesteld om het onderzoek in onderstaande volgorde uit te voeren, omdat niet uitgesloten wordt dat de maatschappelijke acceptatie van het koeiencloset een heikel punt kan zijn. Enerzijds omdat burgers ver af staan van de praktijk van de melkveehouderij en zij 'natuurlijkheid' intuïtief als uitgangspunt kiezen. Anderzijds omdat het verkleinen van de veestapel een alternatieve maatregel is waarbij niemand de effectiviteit in het kader van ammoniakemissie in twijfel trekt. Een extra risico is de mogelijk negatieve beeldvorming dat de sector 'massage van de G-spot bij melkkoeien' beschouwt als een aanvaardbare oplossing voor het ammoniakprobleem. Dit is temeer reden om het publieksonderzoek prioriteit te geven.

\subsubsection{Publieksonderzoek naar de maatschappelijke acceptatie van het gebruik van een closet voor koeien, gekoppeld aan zindelijkheidstraining}

Gebruik van een koeiencloset en zindelijkheidstraining zijn vanwege het innovatieve karakter voor de gemiddelde burger onbekende fenomenen. Dat maakt het vragen naar de mening van burgers hierover, hetzij via een enquête, hetzij via diepte-interviews tot een triviale onderzoeksmethode die geen betrouwbare resultaten zal opleveren. Extra aandacht voor de onderzoeksmethodiek is derhalve van belang. Eerder is door Wageningen Livestock Research onderzoek verricht naar de wenselijkheid van het fokken van ongehoornde (polled) koeien (Windig et al., 2008). Ook dat verschijnsel was bij burgers totaal onbekend. In dat onderzoek zijn goede ervaringen opgedaan met een moderne onderzoekstechniek om de mening van de consument over bepaalde zaken te achterhalen waarbij beïnvloeding vooraf zoveel mogelijk wordt uitgesloten. De methode heet Nextexpertizer en is ontwikkeld aan de universiteit van Bremen. Deze methode wordt vooral gebruikt bij onderzoek naar zaken waarbij van te voren nog geen uitgesproken meningen vastliggen, en waarbij het belangrijk is waarom bepaalde meningen gevormd worden. De methode richt zich op het achterhalen van de 
intuïtieve associaties van mensen met bepaalde zaken. Deze methode lijkt voor het onderzoek naar de maatschappelijke acceptatie van het gebruik van een closet voor koeien, gekoppeld aan zindelijkheidstraining, bijzonder geschikt.

\subsubsection{Praktijkonderzoek naar de effectiviteit van het gebruik van de urineerbox in het kader van ammoniakreductie}

Naast intuïtieve associaties zullen voor de maatschappelijke acceptatie de gevolgen voor de koe en de effectiviteit van het koeiencloset een rol spelen. Omdat koeien vrijwillig voor het toilet kunnen kiezen, is een onderzoek naar de effectiviteit gewenst. Indien blijkt dat deze oplossing in de praktijk te weinig effectief is, kan daarmee (kostbaar) onderzoek naar de gevolgen voor de koe worden bespaard. Dit onderzoek zal onder praktijkomstandigheden met grotere koppels koeien vragen moeten oplossen over de snelheid waarmee (individuele) koeien zich het gebruik van het koeiencloset aanleren en welk deel van de dagelijkse urinelozingen kan worden opgevangen.

\subsubsection{Funderend onderzoek naar de effecten van het gebruik van de urineerbox op het welzijn van koeien}

Zo op het oog lijkt er niet al te veel aan de hand. Koeien komen vrijwillig en worden beloond. De positionering van de urineerbox met stimulatie induceert echter gedrag dat voor tweeërlei uitleg vatbaar is. Het kan zijn dat de koe het aangenaam vindt gestimuleerd te worden. Het gedrag kan echter ook betekenen dat de koe acute stress ondervindt, onrustig wordt en daardoor tot een urinelozing komt. In beide gevallen geldt overigens dat de koe vrijwillig het stimulatiemedium opzoekt.

Indien het gebruik van het koeiencloset voldoende effectief blijkt, is het raadzaam om ook de biologische effecten van het gebruik van het koeiencloset nader in beeld te brengen. Registratie van gedrag (onrust, beweging, kromming van de rug, houding van kop/oren/staart, oogwit), hartslag(variabiliteit) en plasmacortisol bij koeien tijdens urineren in het closet in vergelijking met urineren buiten het closet kan mogelijk uitsluitsel geven over de mate waarin koeien de urineerbox als positief of negatief ervaren. Vergelijkbaar onderzoek is eerder uitgevoerd naar de effecten van automatisch melken (Hopster et al., 2002).

\subsection{Visie op de praktische haalbaarheid}

Koeien kunnen worden getraind om, met een kleine hoeveelheid krachtvoer als beloning, (een deel van) de in de blaas aanwezige urine te lozen in het koeiencloset. Ze wekken de indruk uit vrije wil het koeiencloset te willen bezoeken en lozen hun urine nadat het perineum is gestimuleerd. Het lijkt er sterk op dat de aan het koeiencloset gerelateerde handelingen, voor de koe geen negatieve consequenties heeft. Ook al urineren koeien soms ook als gevolg van acute stress, lijkt dit hier niet direct aan de orde. Vanuit het perspectief van de koe, lijken er geen directe nadelen verbonden aan het gebruik van het koeiencloset. Daarmee is het verhaal echter niet af. Bedenkingen kunnen worden gemaakt op twee andere punten:

1) de haalbaarheid om dit op koppelniveau effectief te laten opereren en

2) de maatschappelijke weerstand tegen deze technologische oplossing waarbij 'zelfs de edele delen van de koe worden geëxploiteerd'.

\subsubsection{Haalbaarheid op koppelniveau}

Individuele koeien trainen om in een kleine groep hun urine in een koeiencloset te lozen lijkt mogelijk. Onder praktijkomstandigheden zal het lastiger worden. Om het closet te bezoeken maken koeien een kosten/baten afweging. De baten bestaan in elk geval uit de beloning met krachtvoer, wellicht verhoogd met de stimulatie van het perineum. Voor dat laatste geldt dat op dit moment niet duidelijk is of dat noodzakelijk is om de meeste urine op te vangen. De belonende werking van krachtvoer is afhankelijk van de motivatie van de koe om energie op te nemen. Zijn koeien weldoorvoed, dan zal die motivatie drastisch afnemen. Om melkgevende koeien optimaal te laten produceren, worden ze in de regel weldoorvoed en valt te betwijfelen of voor de melkgevende koe de baten dan wel tegen de kosten opwegen. Temeer omdat die kosten zeer waarschijnlijk, en in ieder geval voor rang-lage koeien, in een grotere koppel aanmerkelijk hoger kunnen worden. In grotere koppels zijn er langere looplijnen, maar wat belangrijker is: een complexere sociale dynamiek. Toen er in de 80 -er jaren 
experimenten werden uitgevoerd met een systeem waarmee koeien werden opgeroepen met een geluidssignaal om in de krachtvoerbox een beloning op te halen, bleken vooral de sociale verhoudingen tussen koeien een struikelblok. Want willen is dan niet gelijk aan kunnen en competitie rond de krachtvoerbox, waarbij dominante koeien de ingang blokkeerden, bleek een goede werking van het systeem ernstig te frustreren. Bovendien is het zeer de vraag of koeien bereid zijn om 'hun plas volledig op te houden', vooral op momenten dat ze weldoorvoed zijn. Er zijn dan ook nog gerede twijfels over de mogelijkheden om het succes in een kleine groep droge koeien, te extrapoleren naar een praktijkkoppel melkgevende dieren.

\subsubsection{Haalbaarheid in maatschappij}

Bezwaren van burgers tegen praktijken met dieren zijn geënt op nadelen voor de gezondheid en het welzijn van dieren, maar ook op aantasting van de integriteit van en een niet respectvolle omgang met dieren. Een voorbeeld daarvan is het aankomend verbod op koudmerken. Dit thema is in maart 2017 controversieel verklaard en zal dus door het nieuwe kabinet moeten worden opgepakt. Dat verbod heeft weinig te maken met het relatief geringe ongerief dat koeien ondervinden bij het aanbrengen van het koudmerk. Het belangrijkste argument is dat er acceptabele alternatieven zijn en dat koudmerken de integriteit van het dier aantast. Exploitatie van de G-spot van koeien om het ammoniakprobleem op te lossen, zal mogelijk leiden tot negatieve beeldvorming en imagoschade voor de melkveehouderij. Ook wordt verwacht dat deze 'staloplossing' gezien zal worden als een verdere stimulans om koeien weidegang te onthouden, hoewel de urineerbox ook gebruikt kan worden bij weidende dieren, namelijk in de tijd dat ze in de stal verkeren. In die zin zal ook het argument dat de opgevangen urine kan worden opgewerkt tot kunstmestvervanger niet positief worden gepercipieerd. 


\section{Discussie, conclusies, aanbevelingen}

Nico Verdoes en Sjoerd Bokma

\subsection{Discussie en conclusies}

Ammoniak ontstaat zodra mest en urine met elkaar in contact komen. Voorkómen dat dit gebeurt, is dan ook een belangrijke oplossingsrichting. In deze studie lag de focus op het scheiden van urine en feces voordat het op de (loop)vloer terecht komt. Gelet op de anatomie van de blaas en de endeldarm en de aansturing van uitscheidingsgedrag, wordt het theoretisch niet onmogelijk geacht om koeien op zindelijkheid te trainen.

Met betrekking tot de trainbaarheid zijn 2 koeien geleerd op een specifiek fluitsignaal een voerbeloning op te halen. Onder de condities waaronder de pilotstudie is uitgevoerd werd dit onderdeel van het beoogde conditioneringsproces succesvol afgerond. Vervolgens werd getracht om fluitsignaal en voerbeloning te koppelen aan het uitscheidingsgedrag. De proefopzet leidde niet tot gedragingen van de proefkoeien die erop kunnen wijzen dat de dieren het optreden van lozingen van urine associeerden met het verkrijgen van een voerbeloning. Het feit dat alleen lozingen van urine en mest gedurende de dag werden gecombineerd met het fluitje in combinatie met de voerbeloning betekende dat alle eliminaties gedurende de avond en nacht onbeloond bleven. Dit kan het leerproces tenminste vertraagd en wellicht zelfs tegengewerkt hebben. Hiermee is niet gezegd dat het leren urineren op een signaal niet mogelijk is, maar het werd niet haalbaar geacht binnen deze proef. Eerst zal meer fundamenteel onderzoek moeten plaatsvinden naar primary en secondary reinforcers. Een fluitsignaal is niet zo praktisch in een stal waar vele dieren een specifieke toon zullen moeten waarnemen. Ook is een methode die de dieren zichzelf aanleren meer wenselijk in de huidige arbeidsintensieve melkveehouderij dan het individueel trainen.

Activatie van de nervus pudendus (schaamzenuw) door prikkeling van het perineum lijkt mogelijkheden te bieden om koeien via operante conditionering te trainen om, voorafgaand aan de beloning met krachtvoer, eerst te urineren. Uit een verkennend experiment met melkkoeien is het mogelijk gebleken om het urineergedrag op te wekken door middel van kortstondige perineum massage. Een borstel met stugge haren als massagemateriaal gaf de beste respons (gemiddeld ca 28 $\%$ succesvolle urinaties). Er lijkt bovendien sprake te zijn van stijging van de respons naarmate de koeien meer ervaring met de massage krijgen. Het dier moet zich tijdens het stimuleren op haar gemak voelen. In het experiment kregen de koeien geen beloning als zij het gewenste unineergedrag vertoonden. De koeien werden ad random gestimuleerd, zonder kennis van het voorgaande tijdstip waarop een urinelozing plaatsvond. Uit aanvullende waarnemingen van een dierenarts naar de vullingsgraad van de blaas kwam naar voren dat het niet reageren op de massage veelal kon worden verklaard door een geringe vulling van de blaas. Bij gericht stimuleren kan de respons dus nog verhoogd worden.

De "proof of principle" met de urineerbox heeft laten zien dat koeien bereid zijn om voor een beloning frequent naar deze box te gaan. In deze box was nog geen stimulatievoorziening aanwezig. Het gaan urineren in de box werd met wat aanvullend en extra smakelijk voer beloond. Ook werd duidelijk dat de dieren een verband leerden te leggen tussen het urineren en het krijgen van de beloning. In de verbeterde uitvoering van de urineerbox werd wel stimulatiemateriaal ingebouwd om het urineren in gang te zetten. Waargenomen werd dat dieren zelf het perineum naar de stimulatievoorziening brengen en vervolgens gaan urineren om daarna de extra voerbeloning in ontvangst te nemen. De variatie in respons was tot dusver groot.

In het onderzoek is een methode ontwikkeld om staartbewegingen te registreren via sensoren. Deze bewegingen kunnen dan vervolgens gekoppeld worden aan beelden in de stal. Achterliggend doel was om de staartbewegingen als voorspeller te gebruiken dat er mest of urine geloosd zou worden. Vooral gegevens over liggen en staan lijken in combinatie met staartattenties bruikbaar als mogelijke voorspellers van lozingen. De tijd tussen het optillen van de staart en het lozen is echter zodanig kort, dat het lastig zal zijn een automatiseringsmethode te ontwikkelen om mest of urine op te vangen van onder de staart. Wel is inzicht verkregen in de ruimtelijke verdeling van lozingen; met de ontwikkelde 
methode kan de plaats waar geloosd wordt eenvoudig nauwkeurig worden vastgelegd. Kennis over waar en wanneer waarschijnlijk een lozing heeft plaatsgevonden of nog bezig is kan mogelijk ook op andere manieren worden toegepast. Er kan direct actie worden ondernomen om te voorkomen dat koeien over het besmeurde deel van de vloer lopen en de lozing kan - indien het mest betreft - gericht worden opgeruimd. Wellicht kan dit bijdragen aan beperking van de vorming en emissie van ammoniak. Een dergelijk gebruik van staartsensoren vergt wel directe communicatie met overige stalautomatisering.

Het merendeel van de lozingen heeft plaats gevonden op de roostervloer achter de ligboxen, met relatief weinig lozingen vlak achter het voerhek. In hoeverre dit specifiek is voor de stal waarin het onderzoek is uitgevoerd is niet duidelijk. Dergelijke kennis zou ook kunnen worden gebruikt om de inrichting van stallen zodanig aan te passen dat emissies worden beperkt. De ontwikkelde methode om gegevens over mest- en urinelozingen te verzamelen kan hierbij zeer behulpzaam zijn. Aanbevolen wordt ook in andere stalsystemen de plaatsen van lozingen te bepalen. Daarmee kunnen eerder gerichte maatregelen genomen worden voor emissiebeperking. Met de ontwikkelde methode is het nu ook mogelijk om uitwerking 4 van de brainstormsessies uit te voeren: opstaan en opvangen. Bepaald zou moeten worden hoe lang na het opstaan en hoe vaak na het opstaan de dieren urineren of mesten. Gedacht wordt aan een innovatieve ligbox waar de dieren enige minuten vastgehouden kunnen worden, de urine en feces in een bak deponeren en na het lozen de box kunnen verlaten.

Het onderzoek heeft geen aanwijzingen opgeleverd voor verbanden met voeropname, wateropname en melken. Indien lozingsgedrag wordt gemonitord wordt het ook mogelijk om eventuele afwijkingen in gedrag (b.v. tochtigheid) en gezondheid (b.v. stofwisseling) op te sporen.

$\mathrm{Er}$ is een (technisch en economisch) rekenmodel ontwikkeld voor de situatie dat een urineerboxsysteem op een melkveehouderijbedrijf ingezet wordt. Vele invoergegevens kunnen worden gevarieerd en de business cases kunnen worden doorgerekend. In het model wordt uitgegaan van de situatie dat de urine en feces apart wordt opgevangen en verder bewerkt kunnen worden. Met het model wordt duidelijk gemaakt dat er bij toepassing van een urineerbox minder mest van het bedrijf hoeft te worden afgevoerd. Als de urine verder wordt bewerkt tot een kunstmestvervanger hoeft er ook minder kunstmest te worden aangevoerd. Met het model kan ook berekend worden wat de vooren nadelen zijn van een urineerbox als bijvoorbeeld de derogatie zou verdwijnen. Duidelijk is dat een urineerbox op zich economisch niet interessant is als we alleen letten op de beperking van de ammoniakemissie. Het wordt alleen economisch interessant als de afzonderlijke mestproducten gerichter op het bedrijf ingezet kunnen worden. Meest bepalende factoren voor een gunstig resultaat zijn de mestafzetprijs, de investering van de boxen en de veebezetting op het bedrijf. Er is geen rekening gehouden met mogelijke voordelen voor diergezondheid. Die kunnen in dit stadium ook nog niet worden gekwantificeerd, maar zouden relevant kunnen zijn.

Met behulp van een bestaand ammoniakemissiemodel is berekend wat de effecten zijn - rekening houdend met plasgrootte en dikte van de urine laag - van minder urinelozingen op de vloer en van een variërend leef oppervlakte per dier. Vooral het aantal urinelozingen dat nog buiten de urineerbox plaatsvindt is bepalend voor de ammoniakemissie. Wanneer het aantal urinelozingen op de vloer teruggebracht kan worden van 10 naar 2 per dag, daalt de ammoniakemissie uit de stal naar verwachting met $56 \%$. De reductiepotentie is daarmee groot. Het is dus zeker waard om het gescheiden houden bij de bron in het onderzoek verder te verkennen.

\subsection{Aanbevelingen}

Het onderhavige onderzoek had vooral een verkennend karakter om te identificeren of er gedragsmatig mogelijkheden zijn om bij melkkoeien mest direct uit de koe en zo mogelijk gescheiden op te vangen. Het verdient aanbeveling om het op grotere schaal voort te zetten en een beter beeld te krijgen van de inspanning en succeskans om het gericht urineren nader in beeld te krijgen, maar ook om een goede inschatting te kunnen maken van het aandeel en het urinevolume van de urinaties die op deze wijze in een urineerbox worden verzameld, zowel bij weidende dieren als opgestalde dieren. 
Aanbevolen wordt ook onderzoek te doen naar de vragen als:

- Publieksonderzoek naar de maatschappelijke acceptatie van het gebruik van een closet voor koeien, gekoppeld aan zindelijkheidstraining (de maatschappelijke waarden).

- Leren dieren dit in een eerder stadium (als kalf) gemakkelijker aan dan op oudere leeftijd?

- Welke (voer)beloning werkt het beste? Vinden alle koeien hetzelfde voer extra lekker? Zijn er andere vormen van belonen?

- Hoe is het gebruik van de urineerbox als er weidegang op het bedrijf is? En zijn er mogelijkheden om de box in de wei te situeren?

- Welke plaatsen in de stal zijn geschikt voor de urineerbox? Of hoeveel dieren kunnen per box gehouden worden? Zijn er combinaties mogelijk met de krachtvoerbox of de melkrobot?

- Hoe is het uitscheidingspatroon van (verdeeld over het vloeroppervlak) in andere stalsystemen en zijn er mogelijkheden om direct achter de boxen een opvangsysteem te maken?

- Vervolgonderzoek moet ook duidelijk maken of het stimulatiemateriaal voor de koe van cruciaal belang is om zelf een urinatie op te kunnen wekken. Koeien met een volle blaas hebben mogelijk nauwelijks stimulatie nodig, en wellicht kan een andere vorm van stimuleren effectief zijn.

- Heeft het gebruik van de urineerbox en het stimulatiemateriaal invloed op het welzijn van de koe?

- Welke andere nuttige bepalingen in de urine en mest gedaan kunnen worden die b.v. iets over de gezondheid van de dieren zeggen?

- Praktijkmetingen naar de effectiviteit van het gebruik van de urineerbox in het kader van ammoniakreductie (de praktijkvoordelen). 


\section{Literatuur}

Aland, A., Lidfors, L. and Ekesbo, I. 2002. Diurnal distribution of dairy cow defecation and urination. Applied Animal Behaviour Science 78, 43-54.

Aland, A., L. Lidfors, and I. Ekesbo. 2009. Impact of elastic stall partitions on tied dairy cows' behaviour and stall cleanliness. Preventive Veterinary Medicine 92: 154-157.

Auerswald, K., F. Mayer, and H. Schnyder. 2010. Coupling of spatial and temporal pattern of cattle excreta patches on a low intensity pasture. Nutrient cycling in agroecosystems 88: 275-288.

Beerda, B., W. Ouweltjes, L. Šebek, J. Windig, and R. Veerkamp. 2007. Effects of genotype by environment interactions on milk yield, energy balance, and protein balance. Journal of Dairy Science 90: 219-228.

Bergsten, C., and B. Pettersson. 1992. The cleanliness of cows tied in stalls and the health of their hooves as influenced by the use of electric trainers. Preventive Veterinary Medicine 13: 229238.

Betteridge, K. 2015. Personal communication.

Betteridge, K., C. Hoogendoorn, D. Costall, M. Carter and W. Griffiths, 2010. Sensors for detecting and logging spatial distribution of urine patches of grazing female sheep and cattle. Computers and Electronics in Agriculture 73, 66-73.

Betteridge, K, D. Costall, F. Li, D. Luo and S. Ganesh. 2013. Why we need to know what and where cows are urinating-a urine sensor to improve nitrogen models. In Proceedings of the New Zealand Grassland Association, pp. 119-124.

Birder, L.A., S. Wachter, J. Gillespie, and J. J. Wyndaele. 2014. Urethral sensation: Basic mechanisms and clinical expressions. International Journal of Urology 21: 13-16.

Bishop-Hurley, G.S., D.M. Anderson, P. Sikka, C. Crossman and P. Corke. 2007. Virtual fencing applications: Implementing and testing an automated cattle control system. Computers and Electronics in Agriculture 56: 14-22.

Bond, T. A., D. Sear, and M. Edwards. 2012. Temperature-driven river utilisation and preferential defecation by cattle in an English chalk stream. Livestock Science 146: 59-66.

Brantas, G. C. 1968. Training, eliminative behaviour and resting behaviour of Friesian-Dutch cows in the cafetaria stable. Zeitschrift für Tierzüchtung und Züchtungsbiologie 85: 64-77.

Bobbink, R., D. Bal, H.F. van Dobben, A.J.M. Jansen, H. Nijssen, J.H.J. Siepel, N.A. Smits, en W. de Vries. 2008. De effecten van stikstofdepositie op de structuur en het functioneren van ecosystemen.

Bobbink, R., Hornung, M. and Roelofs, J. G. M. (1998), The effects of air-borne nitrogen pollutants on species diversity in natural and semi-natural European vegetation. Journal of Ecology, 86: 717-738

Bos, A.P., J. Cornelissen en P.G.M. Groot Koerkamp, 2010. Mest en urine: van afval naar waardevol product. Syscope, http://edepot.wur.nl/149222Brantas G.C., 1968. Training, eliminative behaviour and resting behaviour of Friesian-Dutch cows in the cafetaria stable. Zeitschrift für Tierzüchtung und Züchtungsbiologie 85, 64-77.

Cao, Z. J., M. Ma, X. Y. Yan, S. L. Li, and X. M. Zhang. 2009. A simple urine-collecting apparatus and method for cows and heifers. Journal of Dairy Science 92: 5224-5228.

Cho, Y. S. et al. 2014. Caffeine enhances micturition through neuronal activation in micturition centers. Molecular medicine reports 10: 2931-2936.

Cunningham, J. G., and B. G. Klein. 2007. The vestibular system. In: J.G. Cunningham, B.G. Klein (eds). Textbook of veterinary physiology, 4th edition, St. Louis, Saunders Elsevier Missouri.

Dixhoorn, I., september 2015. Mondelinge mededeling. Dairy Campus.

Dyce, K. M., W. O. Sack, and C. J. G. Wensing. 2010. Textbook of veterinary anatomy (4th ed.). Elsevier Health Sciences.

Fregonesi, J. A., M. A. G. von Keyserlingk, C. B. Tucker, D. M. Veira, and D. M. Weary. 2009. Neck-rail position in the free stall affects standing behavior and udder and stall cleanliness. Journal of Dairy Science 92: 1979-1985.

Halem, N. van en IJ.D. Jüngen, 2009. Anatomie en fysiologie / Niveau 3. ISBN: 789031362073, Uitgever: Bohn Stafleu van Loghum |

Hirata, M., and M. Higashiyama. 1997. Spatial Distribution of Urination by Cattle in a Daytime Grazing System. Asian-Australasian Journal of Animal Sciences 10: 484-490.

Hirata, M., M. Higashiyama, and N. Hasegawa. 2011. Diurnal pattern of excretion in grazing cattle. Livestock Science 142: 23-32.

Hopster, H., R.M. Bruckmaier, J.T.N. Van der Werf, S.M. Korte, J. Macuhova, G. Korte-Bouws en C.G. van Reenen. 2002. Stress responses during milking; comparing conventional and automatic milking in primiparous dairy cows. Journal of Dairy Science 85(12), 3206-3216

Kumar, J. C., D. Abhizith, and A. Kumar. 2006. Letter to the editor: The suckling-micturition reflex in cows. Journal of Dairy Science 89: 4095.

Kumar, K. R., G. Archunan, R. Jeyaraman, and S. Narasimhan. 2000. Chemical characterization of bovine urine with special reference to oestrus. Veterinary Research Communications 24: 445454. 
Kurien, B. T., N. E. Everds, and R. H. Scofield. 2004. Experimental animal urine collection: a review. Laboratory Animals 38: 333-361.

Lascano, G. J., G. I. Zanton, A. J. Heinrichs, and W. P. Weiss. 2010. Technical note: A noninvasive urine collection device for female cattle: Modification of the urine cup collection method. Journal of Dairy Science 93: 2691-2694.

Lee, C., A. D. Fisher, M. T. Reed, and J. M. Henshall. 2008. The effect of low energy electric shock on cortisol, $\beta$-endorphin, heart rate and behaviour of cattle. Applied Animal Behaviour Science 113: 32-42.

Lee, C., J.M. Henshall, T.J. Wark, C.C. Crossman, M.T. Reed, H.G. Brewer, J. O’ Grady and A.D. Fisher (2009). Associative learning by cattle to enable effective and ethical virtual fences. Applied Animal Behaviour Science 119: 15-22.

Lee, C., K. Prayaga, M. Reed, and J. Henshall. 2007. Methods of training cattle to avoid a location using electrical cues. Applied Animal Behaviour Science 108: 229-238.

Marcillac-Embertson, N. M., P. H. Robinson, J. G. Fadel, and F. M. Mitloehner. 2009. Effects of shade and sprinklers on performance, behavior, physiology, and the environment of heifers. Journal of Dairy Science 92: 506-517.

Metz, J., and J. H. M. Metz. 1986. Maternal influence on defecation and urination in the newborn calf. Applied Animal Behaviour Science 16: 325-333.

Misselbrook, T., H. Fleming, V. Camp, C. Umstatter, C.A. Duthie, L. Nicoll and T. Waterhouse, 2016. Automated monitoring of urination events from grazing cattle. Agriculture, Ecosystems and Environment 230, 191-198.

Monteny, G.J., D.D. Schulte, A. Elzing, and E.J.J. Lamaker (1998) A conceptual mechanistic model for the ammonia emissions from free stall cubicle dairy cow houses, Transactions of the ASAE 41 (1), 193-201.

Munksgaard, L., A. De Passillé, J. Rushen, K. Thodberg, and M. B. Jensen. 1997. Discrimination of people by dairy cows based on handling. Journal of Dairy Science 80: 1106-1112.

Nervig, R., and L. Garrett. 1979. Use of furosemide to obtain bovine urine samples for leptospiral isolation. American journal of veterinary research 40: 1197-1200.

Northway, R. B. 1975. Manual stimulation of micturition. Modern veterinary practice 56: 832.

Oltenacu, P. A., J. Hultgren, and B. Algers. 1998. Associations between use of electric cow-trainers and clinical diseases, reproductive performance and culling in Swedish dairy cattle. Preventive Veterinary Medicine 37: 77-90.

Orr, R. J., B. A. Griffith, R. A. Champion, and J. E. Cook. 2012. Defaecation and urination behaviour in beef cattle grazing semi-natural grassland. Applied Animal Behaviour Science 139: 18-25.

Oudshoorn, F. W., T. Kristensen, and E. S. Nadimi. 2008. Dairy cow defecation and urination frequency and spatial distribution in relation to time-limited grazing. Livestock Science 113: 62-73.

Ouweltjes, W. en J.T.N. van der Werf, 2016. Interne rapportage

Raad voor Dierenaangelegenheden, 2010. Agenda voor het dierbeleid. Den Haag.

Robichaud, M. V., A. M. de Passillé, and J. Rushen. 2013. Does water or blowing air stimulate cows to defecate? Applied Animal Behaviour Science 144: 98-101.

Roche, J. R., D. E. Dalley, and F. P. O'Mara. 2007. Effect of a metabolically created systemic acidosis on calcium homeostasis and the diurnal variation in urine $\mathrm{pH}$ in the non-lactating pregnant dairy cow. Journal of dairy research 74: 34-39.

Rushen, J., L. Munksgaard, P. G. Marnet, and A. M. DePassillé. 2001. Human contact and the effects of acute stress on cows at milking. Applied Animal Behaviour Science 73: 1-14.

Ruud, L. E., C. Kielland, O. Østerås, and K. E. Bøe. 2011. Free-stall cleanliness is affected by stall design. Livestock Science 135: 265-273.

Smits, M.C.J., H. Gunnink \& A.C. Smits (1996), Ammoniak emissie uit een vleesstierenstal: invloed van vloertype, vloeroppervlak en ureaseactiviteit. Wageningen: IMAG-DLO - ISBN $9789054061489-43 \mathrm{p}$.

Sprangers, Sj. 2015. Persoonlijke mededeling, melkveehouder Kaatsheuvel

Ten Haaf, M., and G. van der Linde. 2013. Mest- en urineergedrag van melkvee. HAS, CAH Vilentum.

Umstatter, C. 2011. The evolution of virtual fences: A review. Computers and Electronics in Agriculture 75: 10-22.

Van Es, A., and J. Vogt. 1959. Separate collection of feces and urine of cows. Journal of Animal Science 18: 1220-1223.

Van Halem, N., and I. J. D. Jungen. 2009. Anatomie en fysiologie / deel Niveau 3 / druk 1 / GEB. Bohn Stafleu van Loghum.

Vaughan, A., A. M. de Passillé, J. Stookey, and J. Rushen. 2014a. Operant conditioning of urination by calves. Applied Animal Behaviour Science 158: 8-15.

Vaughan, A., A. M. de Passillé, J. Stookey, and J. Rushen. 2014b. Urination and defecation by grouphoused dairy calves. Journal of Dairy Science 97: 4405-4411.

Villettaz Robichaud, M., A. M. de Passillé, D. Pellerin, and J. Rushen. 2011. When and where do dairy cows defecate and urinate? Journal of Dairy Science 94: 4889-4896.

Wechsler, B., and S. E. G. Lea. 2007. Adaptation by learning: Its significance for farm animal husbandry. Applied Animal Behaviour Science 108: 197-214.

Whistance, L. K., D. R. Arney, L. A. Sinclair, and C. J. C. Phillips. 2007. Defaecation behaviour of dairy cows housed in straw yards or cubicle systems. Applied Animal Behaviour Science 105: 14-25.

Whistance, L. K., L. A. Sinclair, D. R. Arney, and C. J. C. Phillips. 2009. Trainability of eliminative behaviour in dairy heifers using a secondary reinforcer. Applied Animal Behaviour Science 117: $128-136$. 
Whistance, L. K., L. A. Sinclair, D. R. Arney, and C. J. C. Phillips. 2011. Eliminative behaviour of dairy cows at pasture. Applied Animal Behaviour Science 130: 73-80.

White, S., R. Sheffield, S. Washburn, L. King, and J. Green. 2001. Spatial and time distribution of dairy cattle excreta in an intensive pasture system. Journal of Environmental Quality 30: 2180-2187.

Windig, J.J., Hoving-Bolink, R. en R.F. Veerkamp. 2008. Wenselijkheid en mogelijkheden voor het fokken van hoornloze koeien. Fase 1. Wageningen UR Livestock Research, rapport nr. 176, Lelystad.

Wolschrijn, C., 2015, Afdeling Veterinaire Anatomie UU, persoonlijke mededeling

Wredle, E., L. Munksgaard, and E. Spörndly. 2006. Training cows to approach the milking unit in response to acoustic signals in an automatic milking system during the grazing season. Applied Animal Behaviour Science 101: 27-39. 


\section{Bijlage 1 Deelnemers creatieve sessie}

Bedrijfsleven

Helmer Ebbers, Frank Teunissen (Ebbers Metalworks)

Gerben Nooyen (Nooyen Pig Flooring)

Generalist

Bernice Muntz, trainer van dieren

Onderzoekers/experts

Ingrid van Dixhoorn, Hendrik Jan van Dooren, Kees Lokhorst, Wijbrand Ouweltjes, Kees van Reenen

Praktijk

Ellen Severt, Sjaak Sprangers (melkveehouders)

Vrije denker

Astrid Willems

Proces/methode

Bram Bos, Peter Groot Koerkamp

Projectteam

Sjoerd Bokma, Nico Verdoes 


\section{Bijlage 2 Economische uitgangspunten en resultaten}

Uitgangspunten en resultaat referentie

\begin{tabular}{|c|c|c|c|c|}
\hline \multirow{2}{*}{$\begin{array}{l}\text { Omschrijving } \\
\text { Stripper }\end{array}$} & \multicolumn{4}{|c|}{ Investering! Jaarkosten } \\
\hline & $€$ & 25.000 & $€$ & 4.000 \\
\hline Plasbox & & 13.500 & $€$ & 1.823 \\
\hline Extra opslagcapaciteit & & 16.077 & $€$ & 1.367 \\
\hline Investeringsfactor & & 1 & & \\
\hline Totaal & $€$ & 54.580 & $€$ & 7.190 \\
\hline
\end{tabular}

\begin{tabular}{|c|c|c|c|c|c|c|c|}
\hline \multicolumn{8}{|l|}{ Economisch resultaat } \\
\hline \multicolumn{8}{|l|}{ Traditioneel } \\
\hline & & Hoeveelheid & & \multicolumn{2}{|c|}{ Prijs/ aankoop } & \multicolumn{2}{|c|}{ Jaarkosten } \\
\hline Afvoer drijfmest & & 940 & ton/jaar & $€$ & 18,00 & $€$ & 16.912 \\
\hline \multicolumn{2}{|c|}{ Aankoop drijfmest + kosten opslag+aanwenden } & & ton/jaar & $€$ & $-5,00$ & $€$ & - \\
\hline Aankoop kunstmest (N) & & 5400 & kg N/jaar & $€$ & 1,10 & $€$ & 5.940 \\
\hline Aankoop kunstmest $\left(\mathrm{K}_{2} \mathrm{O}\right)$ & & 4400 & $\mathrm{~kg} \mathrm{~K}_{2} \mathrm{O} / \mathrm{jaar}$ & $€$ & 0,65 & $€$ & 2.860 \\
\hline Totaal traditioneel & & & & & & $€$ & 25.712 \\
\hline \multicolumn{8}{|l|}{ Plasbox } \\
\hline Gebruik zuur & salpeterzuur & & & \multicolumn{2}{|c|}{ per eenheid } & \multicolumn{2}{|c|}{ jaarkosten } \\
\hline Afvoer drijfmest & & 291 & 1 ton/jaar & $€$ & 18,00 & $€$ & 5.243 \\
\hline \multicolumn{2}{|c|}{ Aankoop drijfmest + kosten opslag+aanwenden } & & ton/jaar & $€$ & $-5,00$ & $€$ & - \\
\hline Aankoop kunstmest (N) & & & kg N/jaar & $€$ & 1,10 & $€$ & - \\
\hline Aankoop kunstmest $\left(\mathrm{K}_{2} \mathrm{O}\right)$ & & 949 & $9 \mathrm{~kg} \mathrm{~K}_{2} \mathrm{O} / \mathrm{jaar}$ & $€$ & 0,65 & $€$ & 617 \\
\hline Investering plasbox & & 3,0 & stuks & $€$ & 4.500 & $€$ & 1.823 \\
\hline \multicolumn{8}{|l|}{ Stripper } \\
\hline Rente, afschrijving, onderhoud & & & & & & $€$ & 4.000 \\
\hline Electriciteit & & & $2 \mathrm{~kW}$ & & 8760 & $€$ & 1.314 \\
\hline Chemicalien (calciumhydroxide + zuur) & & 4904 & $4 \mathrm{~kg} \mathrm{~N}$ verwijdering uit urine & $€$ & 1,20 & $€$ & 5.885 \\
\hline Opslag $\mathrm{N}$-arme urine & & 320 & $\mathrm{~m}^{3}$ & $€$ & 40 & $€$ & 1.088 \\
\hline Opslag spuiwater & & 66 & $6 \mathrm{~m}^{3}$ & $€$ & 50 & $€$ & 279 \\
\hline Gebruik water & & 154 & $4 \mathrm{~m}^{3}$ & $€$ & 1,00 & $€$ & 154 \\
\hline \multicolumn{2}{|l|}{ afvoer/Aanwenden en menging spuiwater } & 113 & $3 \mathrm{~m}^{3}$ & $€$ & 4,00 & $€$ & 450 \\
\hline Totaal Plasbox & & & & & & $€$ & 20.851 \\
\hline Resultaat plasbox & & & & & & $€$ & 4.861 \\
\hline
\end{tabular}

In de spreadsheet wordt gerekend met kosten voor afvoer/aanwending van het spuiwater $€ 4$ per $\mathrm{m}^{3}$. Deze $€ 4$ per $\mathrm{m}^{3}$ is als volgt berekend: in het referentiescenario kan $80 \%$ van het spuiwater op eigen bedrijf worden aangewend ( $€ 2-3$ per $\mathrm{m}^{3}$ ) en $20 \%$ moet worden afgevoerd (ca $€ 12,50$ per $\mathrm{m}^{3}$ ). 


\section{Economische resultaten Referentie en Scenario's}

\begin{tabular}{|c|c|c|c|c|c|c|c|c|c|c|c|c|c|}
\hline & \begin{tabular}{|l} 
Scenario's \\
Referentie
\end{tabular} & \multicolumn{2}{|l|}{ Veedichtheid } & \multicolumn{2}{|c|}{ Mestafzetprijs } & \multicolumn{2}{|c|}{ Investeringen } & \multicolumn{2}{|c|}{ Gift dierlijke mest } & \multirow{2}{*}{$\begin{array}{l}\text { Aankoop Kali } \\
\text { Kali Laag }\end{array}$} & \multirow{2}{*}{$\begin{array}{l}\text { Wassen met } \\
\text { Citroenzuur } \\
\text { ipv salpeterzuur }\end{array}$} & \multirow{2}{*}{$\begin{array}{l}\text { Wassen met } \\
\text { Zwavelzuur } \\
\text { ipv salpeterzuur }\end{array}$} & \multirow{2}{*}{$\begin{array}{l}\text { Combinatie } \\
\text { Optimum }\end{array}$} \\
\hline Uitgangspunten & Referentie & VDH Hoog & VDH Laag & MAP Hoog I & MAP Laag & Inv Hoog & Inv Laag & GDM Hoog & GDM Laag & & & & \\
\hline Aantal melkkoeien: & 100 & 100 & 100 & 100 & 100 & 100 & 100 & 100 & 100 & 100 & 100 & 100 & 110 \\
\hline Jongvee < 1 jaar (aantal): & 35 & 35 & 35 & 35 & 35 & 35 & 35 & 35 & 35 & 35 & 35 & 35 & 35 \\
\hline Jongvee >1 jaar (aantal): & 35 & 35 & 35 & 35 & 35 & 35 & 35 & 35 & 35 & 35 & 35 & 35 & 35 \\
\hline Hoeveelheid grasland ha & 40 & 30 & 50 & 40 & 40 & 40 & 40 & 40 & 40 & 40 & 40 & 40 & 40 \\
\hline (aantal melkoeien per ha gras: & 2,50 & 3,33 & 2,0 & 2,5 & 2,5 & 2,5 & 2,5 & 2,5 & 2,5 & 2,5 & 2,50 & 2,50 & 2,75 \\
\hline Hoeveelheid bouwland: ha & 8,0 & 6,0 & 10,0 & 8,0 & 8,0 & 8,0 & 8,0 & 8,0 & 8,0 & 8,0 & 8,0 & 8,0 & 8,0 \\
\hline Maximale gift dierlijke mest (Kg N/ha) & 230 & 230 & 230 & 230 & 230 & 230 & 230 & 250 & 170 & 230 & 230 & & 230 \\
\hline Mestafzetprijs $\left(€ / \mathrm{m}^{3}\right)$ & 18,00 & 18,00 & 18,00 & 25,00 & 10,00 & 18,00 & 18,00 & 18,00 & 18,00 & 18,00 & 18,00 & 18,00 & 25,00 \\
\hline Investeringen & $€ \quad 54.600$ & 54.600 & 54.600 & $€ \quad 54.600$ & 54.600 & € 81.900 & 36.400 & 54.600 & 54.600 & 54.600 & 54.600 & 54.600 & 40.500 \\
\hline Aankoop kunstmest $\mathrm{K}_{2} \mathrm{O}$ (kg/ha gras) & 100 & 100 & 100 & 100 & 100 & 100 & 100 & 100 & 100 & 0 & 100 & 100 & 100 \\
\hline Aankoop kunstmest $\mathrm{K}_{2} \mathrm{O}(\mathrm{kg} / \mathrm{ha} \mathrm{mais})$ & 50 & 50 & 50 & 50 & 50 & 50 & 50 & 50 & 50 & 0 & 50 & 50 & 50 \\
\hline \multicolumn{14}{|l|}{ Traditioneel } \\
\hline Afvoer drijfmest & $€ \quad 16.912$ & 25.496 & 8.328 & $€ \quad 23.489$ & 9.396 & $€ 16.912$ & 16.912 & 14.271 & 24.836 & 16.912 & 16.912 & 16.912 & 29.302 \\
\hline Aankoop drijfmest & - & - & - & $€ \quad-$ & - & $€ \quad-$ & - & - & - & - & - & - & - \\
\hline Aankoop kunstmest (N) & 5.940 & 4.455 & 7.425 & 5.940 & 5.940 & 5.940 & 5.940 & 5.500 & 7.260 & 5.940 & 4.400 & 4.400 & 5.940 \\
\hline Aankoop kunstmest $\left(\mathrm{K}_{2} \mathrm{O}\right)$ & 2.860 & 2.145 & 3.575 & 2.860 & 2.860 & 2.860 & 2.860 & 2.860 & 2.860 & $€$ & 2.860 & 2.860 & 2.860 \\
\hline Totaal traditioneel & 25.712 & 32.096 & 19.328 & $€ \quad 32.289$ & 18.196 & $€ 25.712$ & 25.712 & 22.631 & 34.956 & 22.852 & 24.172 & 24.172 & 38.102 \\
\hline Plasbox & jaarkosten & jaarkosten & jaarkosten & jaarkosten & jaarkosten & jaarkosten & jaarkosten & jaarkosten & jaarkosten & jaarkosten & jaarkosten & jaarkosten & jaarkosten \\
\hline Afvoer drijfmest & $€ \quad 5.243$ & $€ \quad 13.827$ & $€ \quad-$ & $€ \quad 7.281$ & $€ \quad 2.913$ & $€ \quad 5.243$ & $€ \quad 5.243$ & $€ \quad 2.601$ & $€ \quad 13.166$ & $€ \quad 5.243$ & 5.243 & $€ \quad 5.243$ & $€ \quad 11.470$ \\
\hline Aankoop drijfmest & - & - & -928 & - & - & - & - & - & - & - & - & - & - \\
\hline Aankoop kunstmest (N) & $€$ & $€$ & - & $€$ & $€$ & $€$ & $€$ & $€$ & - & - & 687 & 6.066 & $€$ \\
\hline Aankoop kunstmest $\left(\mathrm{K}_{2} \mathrm{O}\right)$ & 617 & $€$ & 1.189 & 617 & 617 & 617 & 617 & 617 & 617 & $€$ & 617 & 617 & 350 \\
\hline Investering plasbox & 1.823 & 1.823 & 1.823 & 1.823 & 1.823 & 2.734 & 1.216 & 1.823 & 1.823 & 1.823 & 1.823 & 1.823 & 1.621 \\
\hline \multicolumn{14}{|l|}{ Stripper } \\
\hline Rente, afschrijving, onderhoud & 4.000 & 4.000 & 4.000 & 4.000 & 4.000 & 6.000 & 2.668 & 4.000 & 4.000 & 4.000 & 4.000 & 4.000 & 2.668 \\
\hline Electriciteit & 1.314 & 1.314 & 1.314 & 1.314 & 1.314 & 1.314 & 1.314 & 1.314 & 1.314 & 1.314 & 1.314 & 1.314 & 1.314 \\
\hline Chemicalien & 5.885 & 5.885 & 5.885 & 5.885 & 5.885 & 5.885 & 5.885 & 5.885 & 5.885 & 5.885 & 8.337 & 5.885 & 6.473 \\
\hline Opslag urine & 1.088 & 1.088 & 1.088 & 1.088 & 1.088 & 1.631 & 725 & 1.088 & 1.088 & 1.088 & 1.088 & 1.088 & 798 \\
\hline Opslag spuiwater & 279 & 279 & 279 & 279 & 279 & 418 & 186 & 279 & 279 & 279 & 279 & 279 & 205 \\
\hline Kosten waterverbruik & 154 & 154 & 154 & 154 & 154 & 154 & 154 & 154 & 154 & 154 & 159 & 159 & 169 \\
\hline Aanwenden en menging spuiwater & 450 & 450 & 450 & 450 & 450 & 450 & 450 & 450 & 450 & 450 & 450 & 450 & 495 \\
\hline Totaal Plasbox & 20.851 & 28.818 & 15.252 & $€ \quad 22.890$ & 18.521 & $€ 24.445$ & 18.457 & 18.210 & 28.775 & 20.234 & 23.995 & 26.922 & 25.562 \\
\hline Resultaat plasbox (per jaar) & 4.861 & 3.278 & 4.076 & 9.400 & -325 & 1.267 & 7.255 & 4.421 & 6.181 & 2.618 & 178 & -2.750 & 12.540 \\
\hline
\end{tabular}





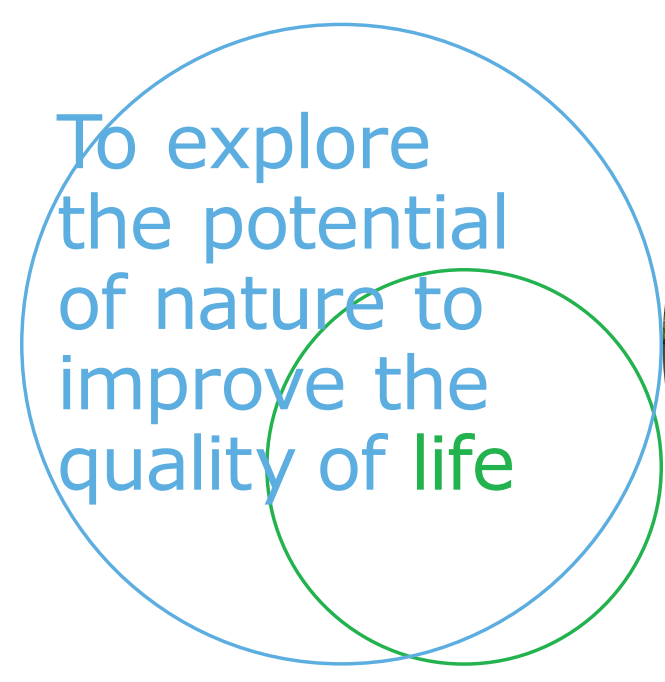

Wageningen Livestock Research Postbus 338 $6700 \mathrm{AH}$ Wageningen

T 0317483953

E info.livestockresearch@wur.nl www.wur.nl/ livestock-research

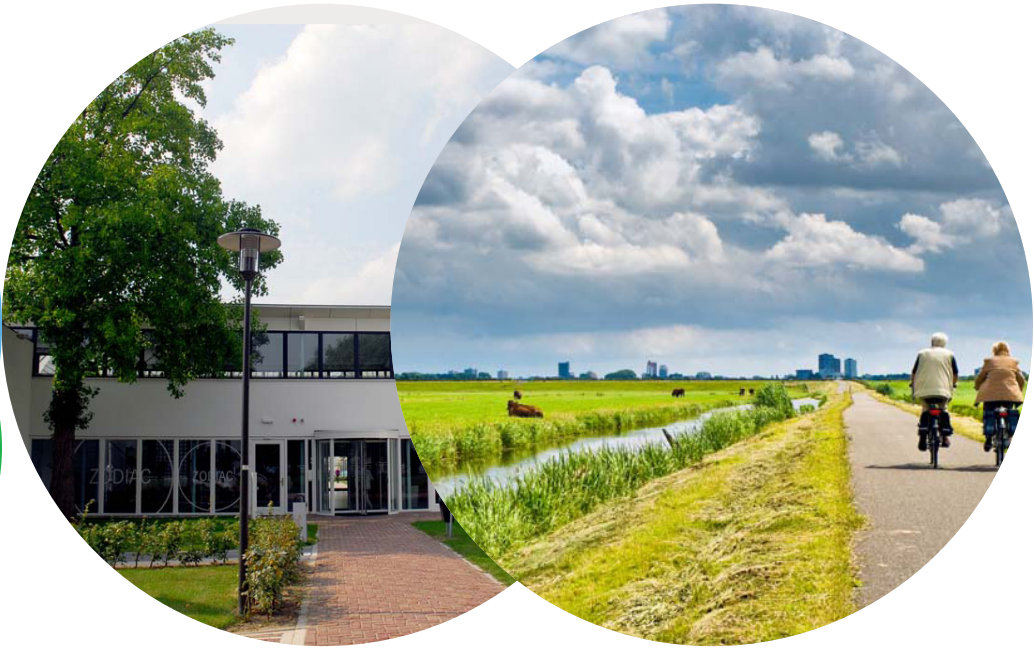

Wageningen Livestock Research ontwikkelt kennis voor een zorgvuldige en renderende veehouderij, vertaalt deze naar praktijkgerichte oplossingen en innovaties, en zorgt voor doorstroming van deze kennis. Onze wetenschappelijke kennis op het gebied van veehouderijsystemen en van voeding, genetica, welzijn en milieu-impact van landbouwhuisdieren integreren we, samen met onze klanten, tot veehouderijconcepten voor de $21 \mathrm{e}$ eeuw.

De missie van Wageningen University \& Research is 'To explore the potential of nature to improve the quality of life'. Binnen Wageningen University \& Research bundelen 9 gespecialiseerde onderzoeksinstituten van Stichting Wageningen Research en Wageningen University hun krachten om bij te dragen aan de oplossing van belangrijke vragen in het domein van gezonde voeding en leefomgeving. Met ongeveer 30 vestigingen, 6.500 medewerkers en 10.000 studenten behoort Wageningen University \& Research wereldwijd tot de aansprekende kennisinstellingen binnen haar domein. De integrale benadering van de vraagstukken en de samenwerking tussen verschillende disciplines vormen het hart van de unieke Wageningen aanpak. 